\title{
Rani Mongoli - etnopolitička povijest do 13. stoljeća
}

DOI:10.11567/met.31.1.3

UDK: 94(=512.3)"0/12"

Pregledni rad

Primljeno: 08. 07. 2014.

Prihvaćeno: 17. 03. 2015.

\author{
Nenad Vidaković \\ Križ \\ nenad.vidakovic1@zg.t-com.hr
}

\section{SAŽETAK}

U radu se istražuje etnogeneza mongolskih plemena od razdoblja plemenskih saveza Róurán i Shìwéi do ujedinjenja početkom 13. stoljeća pod Džingis-kanovim vodstvom. Početno razdoblje etnogeneze predaka srednjovjekovnih Mongola povezano je s plemenskim savezima Róurán i Shìwéi, a vijesti o njima zapisane su u kineskim dinastijskim kronikama. U sastavu saveza Shìwéi nalazilo se i pleme Mengwu, koje je naseljavalo šumska prostranstva sjeverozapadne Mandžurije, a porječje rijeke Argun smatra se pradomovinom Mongola. Nadalje se istražuju smjerovi i vrijeme migracijskih procesa, koji su imali važnu ulogu u transformaciji dijela mongolskih plemena iz šumskih lovaca u stepske nomade. Etnička povijest mongolskih plemena usko je povezana s turkijskim i tungusko-mandžurskim plemenima. Turkijska plemena, koja su naseljavala stepe današnje Mongolije, imala su presudnu važnost u razvoju mongolskih nomadskih plemena, dok su tungusko-mandžurska i sjeverna mongolska plemena zajedno dijelila šumska prostranstva Mandžurije i Zabajkalja. U nastavku teksta opisuju se događaji u turkijskim kaganatima i carstvima na sjeveru Kine koji su utjecali na povijesni razvoj mongolskih plemena. Od velike je važnosti razdoblje qidanske dinastije Liao (10. - 12. stoljeće) jer se tada u sjeveroistočnoj Mongoliji formirala jezgra mongolskih nomadskih plemena, koja su se postupno širila stepom prema zapadu. U razdoblju džurčedske dinastije Jin (12. - 13. stoljeće) porasla je važnost mongolskih plemena na stepi. Tada se kod Mongola javljaju pokušaji političkog ujedinjenja - prvi put sredinom 12. stoljeća za vrijeme vladavine Habul-kana. U završnom dijelu rada opisuje se borba Temudžina, budućeg Džingiskana, za ujedinjenje mongolsko-turkijskih plemena. Nakon pobjede nad najvažnijim suparnicima - Tatarima, Najmanima, Kereitima i Merkitima - Džingis-kan je 1206. uspostavio vlast nad plemenima Mongolije. Tim događajem završilo je prvo razdoblje u etnogenezi srednjovjekovnih Mongola i počelo stvaranje najveće države u povijesti - Mongolskog Carstva.

KLJUČNE RIJEČI: mongolska plemena, Ergune-kun, migracije, kineske dinastije, Džingis-kan, stepa, turkijska plemena 


\section{PLEMENSKI SAVEZ RÓURÁN}

Krajem 2. stoljeća, nakon raspada xianbeiskoga plemenskog saveza, počeli su na istoku euroazijske stepe migracijski i etnički procesi iz kojih će nastati dva nova etnosa - Róurán (柔然) ili Ruănruăn (䗎蝡) ${ }^{1}$ u Mongoliji i Shìwěi (室韋) u sjevernoj Mandžuriji. Prema mišljenju istraživačâ mongolske povijesti, upravo su ti etnosi bili jezgra koja je dala impuls početnom razdoblju etnogeneze Mongola. U kineskim dinastijskim kronikama ${ }^{2}$ Róuráni su opisani kao vješti nomadi koji su vodili gotovo neprekidne borbe s turkojezičnim plemenima na sjeveru, od kojih su najvažniji bili Gāochē (高车) ili Tiělèi (鐵勒), i carstvom Sjeverni Wei ${ }^{3}$ (Běi Wèi 北魏 386. - 535.) na jugu. Prema jednome mišljenju, taj je etnos nastao u drugoj polovini 4. stoljeća od razbijenih rodova turkojezičnih Xiōngnúa (匈奴) i mongolojezičnih Mùrónga (慕容), koji su nakon poraza od Tuòbá bježali na sjever u Mongoliju (Крюков, Малявин і Софронов, 1979: 26). Iako je etnički sastav Rouranskoga Kaganata bio heterogen (Хандсурэн, 1993: 75), većina znanstvenika smatra kako se jezgra Róurána razvila iz (proto)mongolske komponente. Tako B. B. Dašibalov smatra Róuráne potomcima dijela drevnih mongolojezičnih plemena Dōnghú (東胡), koji su nakon poraza od Xiōngnúa migrirali na sjeverozapad i nastanili se u stepama iza Hinganskoga gorja (Дашибалов, 2005: 55). Ruski povjesničar S. G. Kljaštornyj dijeli ih na tri osnovne etnopolitičke skupine - ostaci drevnih plemenskih saveza Awar (Wūhuán 烏桓) i Särbi (Xiānbēi 鮮卑), a iz jednog od njih bio je i vladajući rod Yùjiǔlú (郁久閭), poslije etnopolitonim Róurán i etnopolitonim Tătăr (塔塔 兒) ${ }^{4}$ koji je nastao tijekom političkih i međuplemenskih sukoba (Кляшторний

1 U povijesnim izvorima taj se etnonim pojavljuje i u oblicima Rúrú (蠕蠕), Ruìruì (苁苁), Rúrú (茹 茹) i Tántán (檀檀).

2 Najvažniji su izvori za povijest Róurána dinastijske kronike Povijest dinastije Wei (Wèishū 魏书), pogl. 103, iz 6. stoljeća, Povijest dinastije Song (Sòngshū 宋書), pogl. 95, iz 6. stoljeća, Povijest dinastije Liang (Liángshū 梁書), pogl. 54, iz 7. stoljeća, i Povijest sjevernih dinastija (Běishǐ 北 史), pogl. 98, iz 7. stoljeća (Таскин, 1984: 267-295).

3 Poznato i kao Tuòbá Wèi (拓拔魏) jer su vladari bili iz xianbeiskog roda Tuòbá (拓拢) ili Tabgač (sttur. Tabyač 人'‘S\$). Nakon seobe u sjevernu Kinu osnovali su u 4. stoljeću carstvo Dài (代 338 . - 377.), koje je osvojilo carstvo Raniji Qin (Qián Qín 前秦 351. - 394.). Slabljenjem carstva Qin, Tuòbá Guī (拓跋珪 386. - 409.), unuk posljednjeg daiskog vladara, proglasio je samostalnost i osnovao carstvo Sjeverni Wei. Do 439. weiski vladari ujedinili su sjevernu Kinu (Gernet, 1990: 190-191; Grousset, 1970: 60-61; Кляшторный і Савинов, 2005: 48-50).

4 Etnonim Tatar Kljaštornyj je izveo od imena rouranskoga kagana Dàtána (大檀 414. - 419.), koje se izvorno izgovaralo kao *dadar/*tatar. Vrijeme nastanka tatarskoga plemenskog saveza stavio je u dvadesete godine 5. stoljeća (Кляшторний і Савинов, 2005: 57). Najstariji zapis tog etnonima nalazi se u Orhonskim natpisima, staroturskim izvorima iz prve polovine 8. stoljeća (sttur. 咶占) (Кляшторный і Султанов, 2009: 210; Малов, 1959: 32, 35, 40; Тугушева, 2008: 97, 105, 182). U kineskim izvorima prvi se put pojavljuje 842. u obliku Dádàn (達但). Ostali oblici toga etnonima u kineskim zapisima jesu Dádá (達靼), Dádá (達達), Dádǎ (达打), Dádá (達怛), Dádàn (達旦) i Tătán (塔壇). 
і Савинов, 2005: 58). Mongolsko podrijetlo potvrđuju i etimološka istraživanja naziva kaganata ${ }^{5}$ (Кляшторний і Савинов, 2005: 58; Сухбаатар, 1996: 72), kaganskih titula, osobnih imena ${ }^{6}$ i imena rodova (Хандсурэн, 1993: 69-74). U orhonskim natpisima Róuráni se navode pod imenom Apar (sttur. 41) (Малов, 1951: 21, 29, 36; Тугушева, 2008: 27, 39, 161), vjerojatno izvedeno od etnonima Awar. Prema P. B. Goldenu, taj je etnonim možda nastao iz mongolskoga korijena abar, "penjati se ili puzati«, prisutnog u riječi abarga, »zmija, zmiji slično kretanje«, što odgovara kineskom ruăn (蝡), »puzanje, gmizanje«, i odnosi se ili na pletenice kose ili na zmijski totem (Golden, 1992: 76; Heršak i Silić, 2002: 199). ${ }^{7}$

U drugoj polovini 4. stoljeća, nakon smrti Dìsùyuána (地粟袁), rouranska horda raspala se na zapadni i istočni dio. Ponovno ujedinjenje Róurána postigao je njihov prvi pravi vladar Shèlún (社崙 402. - 410.), koji je zbog neuspjeha u borbi s carstvom Sjeverni Wei bio primoran premjestiti svoj dvor sjeverno od pustinje Gobi. U daljnjem tijeku događaja pokorio je turkojezične Gāochē, plemena u dolini rijeke Tuul i xiongnuska plemena zapadno i sjeverozapadno od rijeke Orhon, čime je učvrstio vlast na mongolskoj stepi. U to doba Rouranski Kaganat prostirao se od države Yānqi ${ }^{8}$ (焉者) na zapadu do države Cháoxiăn ${ }^{9}$ (朝鮮) na istoku, na sjeveru

Kineski hijeroglifi 柔然 (róurán) sredinom 1. tisućljeća najvjerojatnije su se izgovarali *nönör, što u staromongolskom odgovara riječi nökör, »drugi, drukčiji«. Poslije se semantičko značenje pojma proširilo i ponajprije je označivalo vojnika, člana vojne družine, koje nisu bile ustrojene prema rodovsko-plemenskom principu. Prema Kljštornyju, izvorni naziv Rouranskoga Kaganata bio je Nökör (Кляшторний і Савинов, 2005: 58). Mongolski znanstvenik G. Suhbaatar smatra da je izvorni naziv bio Nirun, što je drevni oblik suvremene mongolske riječi nuruu - »leđa, kralježnica« (Сухбаатар, 1996: 73).

6 Kako navodi dinastijska kronika Weishu (Таскин, 1984: 267), predak Rourana bio je rob nepoznata imena, koji je u carstvu Sjeverni Wei nazvan Mùgŭlü (木骨閭). Etimologiju toga imena neki autori izvode iz mongolskih riječi (Miyakawa i Kollautz, 1968: 183; Таскин, 1984: 398-399). Također, neki su u njemu vidjeli prvotni oblik budućeg etnonima Mongol (Кычанов, 1997: 74; Miyakawa i Kollautz, 1968: 183; Сухбаатар, 1996: 73; Зориктуев, 2011а: 51).

7 Chēlùhuì (車鹿會), sin Mùgǔlúa, nazvao je svoj narod Róurán i prihvatio vrhovništvo carstva Sjeverni Wei. No weiski car Tàiwǔ Dì (太武帝 424. - 452.) smatrao je da bi se to ime trebalo promijeniti u Ruănruăn jer su oni »nebitni kao crvi« (Таскин, 1984: 267, 399). Njemački znanstvenik H. W. Haussig smatrao je kako etnonim Ruănruăn dolazi od turkijskoga qurt, »crv, vuk«, jer je njihova totemistička životinja bio vuk. Prema tome objašnjenju, Róuráni su bili turkijskog porijekla (Haussig, 1966: 118).

8 Yānqí ili Karašar, drevno budističko kraljevstvo u Tarimskoj kotlini (istočni Turkestan), dio pokrajine Xīnjiāng (新疆) u sjeverozapadnoj Kini. U razdoblju dinastije Hàn (漢 206. pr. Kr. - 220. p. Kr.) bilo je jedno od važnijih država na Sjevernom putu svile. U kineskim izvorima to se područje nazivalo »zapadni kraj« (Xīyù 西域). Neki autori navode rijeku Ili u Tarimskoj kotlini kao zapadnu granicu Rouranskoga Kaganata.

9 Drevni kineski naziv za prvu protokorejsku državu (početak 1. tisućljeća pr. Kr. - 108. pr. Kr.), koja je obuhvaćala sjever Korejskog poluotoka i dijelove južne Mandžurije. U ranome srednjem vijeku taj se naziv odnosio na državu Koguryŏ (高句麗, 37. pr. Kr. - 668.). Vorob'ev smatra kako je upitna istočna granica Kaganata jer se u izvorima nigdje ne navodi da su Róuráni pokorili narod Qìdān koji je živio zapadno od Koguryŏ (Воробьев, 1994: 298). 
do Hànhăia ${ }^{10}$ (瀚海) i na jugu približno do pustinje Gobi (Grousset, 1970: 61; Хандсурэн, 1993: 75-78; Кычанов, 1997: 75; Крадин, 2007: 154; Miyakava i Kollautz, 1968: 183; Таскин, 1984: 268-270; Воробьев, 1994: 298).

Rouranski Kaganat bio je tipična »carska konfederacija«. Osim rouranskih plemena u sastavu toga stepskog carstva bilo je više, etnički srodnih i etnički različitih, »država« i plemena koja su prihvatila vrhovnu vlast Shèlúna te silom pripojenih naroda kao Gāochē i xiongnuska turkojezična plemena (Крадин, 2007: 153; Таскин, 1984: 269, 271, 278). Veliku važnost za povijest Kaganata imala su upravo turkijska plemena, koja su povećala njegovu vojnu snagu i opskrbljivala Róuráne deficitarnim proizvodima (Гумилев, 2005: 17). Jedna takva vazalna zajednica bio je rod/pleme Ašina ${ }^{11}$ (kin. Āshřnà, 阿史那), nastanjen oko Altaja, koji su za gospodare proizvodili i obrađivali željezo.

Kada se 534. carstvo Sjeverni Wei raspalo na Zapadni Wei (Xī Wèi 西魏 535. - 557.) i Istočni Wei (Dōng Wèi 東魏 534. - 550.), na stepi su počeli procesi u kojima su Turci Ašina imali ključnu ulogu i koji su u svojoj završnici doveli do uništenja Rouranskoga Kaganata. Sukob koji je izbio između Zapadnog i Istočnog Weia bio je za njih veliki teret i njihovi su vođe potražili saveznike. Carstvo Istočni Wei sklopilo je savez s Róuránima, dok je izaslanstvo Zapadnog Weia 545. stiglo Turcima Ašinima, koji su već ovladali prostorom od Altaja do obala Žute rijeke. Turski vođa Bumïn (sttur. J\>S; kin. Tǔmén 土门) ojačao je svoj položaj kada je pokorio plemena Tiělè (pedeset tisuća obitelji), ali je i dalje priznavao vrhovnu vlast rouranskoga kagana. Ostvarenje glavnoga političkog cilja, oslobađanja od rouranske vlasti, Bumïn je započeo 552., kada se obrušio na Róuráne, koji su doživjeli potpuni poraz. Rouranski Kaganat bio je uništen, kagan Ānàgūi (阿那 瓌 520. - 552.) oduzeo si je život, ali Róuráni su još neko vrijeme pružali otpor. U dramatičnim događajima dio Róurána bio je istrijebljen, najveći dio prihvatio je vlast Turaka, manji dio vlast sjevernokineskog carstva Zapadni Wei, dok su neki rodovi/plemena migrirali na zapad i istok (Christian, 1998: 238; Golden, 1992: 79, 127; Grousset, 1970: 81; Гумилев, 2005: 31-36; Хандсурэн, 1993: 87-88; Кляшторний і Савинов, 2005: 82-83; Miyakawa i Kollautz, 1968: 204-208;

10 Taj geografski pojam autori tumače različito. Prema Kyčanovu, riječ je o području oko gornjeg toka Amura, dok Vorob'ev smatra da se odnosi na Bajkalsko jezero (Кычанов, 1997: 75; Воробьев, 1994: 298).

11 U izvorima se povijest roda/plemena Ašina može pratiti od 3. stoljeća. Navode se kao jedna od etnički heterogenih zajednica u provinciji Gānsù (甘肅), sastavljena od »različitih Hu« (zá Hú 雜胡). Bili su u sastavu xiongnuske države Sjeverni Liang (Běi Liáng 北凉 398. - 439.), koju je osvojio sjevernoweiski vladar Tàiwǔ Dì. Ašine i ostaci xiongnuskoga vladajućega klana Jǔqú (沮 渠) pobjegli su u Gāochāng (高昌) u provinciji Xīnjiāng, gdje su se održali do 460., kada su ih pobijedili Róuráni. Ašine su nakon tih događaja naseljeni na južne obronke Altajskoga gorja, gdje su prihvatili novi etnonim Türk (sttur. FrNh; kin. Tūjué 突厥) (Golden, 1992: 121; Гумилев, 2005: 27, 29; Кляшторний і Савинов, 2005: 78-79). 
Таскин, 1984: 291-295; Воробьев, 1994: 299). Dio Róurána, izbjeglih na istok, nastanio se uz gornji tok Amura i u sjeverozapadnoj Mandžuriji, gdje su ušli u sastav shiweiskoga i moheskoga plemenskog saveza, dok su neki migrirali još dalje na istok u korejsku državu Koguryŏ (Кляшторный, 1995: 60; Кляшторный i Савинов, 2005: 83-84; Шавкунов, 1968: 40; Таскин, 1984: 295).

Prema burjatskom povjesničaru B. R. Zoriktuevu, u etničkim i migracijskim procesima povezanim s početnim razdobljem etnogeneze Mongola najvažniju ulogu imao je dio Róurána koji su migrirali na rijeku Argun, područje naseljeno shiweiskim plemenima, gdje su se identificirali s drevnim mongolskim vladajućim rodom Börte-Činō ${ }^{12}$ i Qo'ai-Maral. Za vrijeme boravka na Argunu počela se formirati skupina rodova Darlekin, koja je nakon migracije u mongolsko Trorječje (gornji tok Onona, Kerulena i Tuule) postala jezgra srednjovjekovnih Mongola (Зориктуев, 2003: 53, 54; 2010b: 98; 2011a: 42-43; 2011b: 48, 56).

\section{PLEMENSKI SAVEZ SHÌWÉI}

U prvim stoljećima kršćanske ere oko sjevernih xianbeiskih plemena formirao se plemenski savez, u kineskim dinastijskim kronikama ${ }^{13}$ poznat pod nazivom

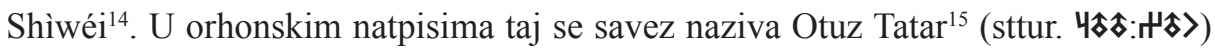
(Цыбиктаров, 2001: 189; Кляшторный і Савинов, 2005: 145; Малов, 1951: 21, 29, 36; Тугушева, 2008: 27, 39, 161; Викторова, 1958: 59-62; 1980: 156). Najdetaljniji prikaz nastanka shiweiskog saveza dao je ruski povjesničar E. V. Šavkunov. Prema njemu, prodor xianbeiskih plemena na sjever i sjeveroistok Mandžurije, područje važno za etnogenezu tungusko-mandžurskih plemena (Ларичев, 1980: 8), pос̌еo je već u vrijeme vladavine Tánshíhuáia (檀石槐). No odmah poslije njegove smrti xianbeiska plemena raspala su se na niz manjih saveza, koji su, pritisnuti s juga od jačih susjeda, bili prisiljeni napustiti svoja područja. Migrirali su na područje oko gorja Veliki Hingan (kin. Dà Xīng’ān lǐng 大興安嶺), a otuda još dalje na sjever i

12 Cinu-a ili čino (kin. Chìnà 赤那), mongolski naziv za vuka. Poput Turaka i srednjovjekovnim Mongolima vuk je bio totemistička životinja.

13 Najvažniji su izvori za povijest Shìwéia dinastijske kronike Povijest dinastije Wei (Wèishū 魏 書), pogl. 100, iz 6. stoljeća, Povijest dinastije Sui (Suíshū 隋書), pogl. 84, iz 7. stoljeća, Povijest Sjevernih dinastija (Běishř 北史) pogl. 94, iz 7. stoljeća, Stara povijest dinastije Tang (Jiù Tángshū 舊唐書), pogl. 199, iz 10. stoljeća, i Nova povijest dinastije Tang (Xīn Tángshū 新唐書), pogl. 219, iz 11. stoljeća (Бичурин, 1950: 76-78; Таскин, 1984: 135-141).

14 U historiografiji je uglavnom prihvaćeno mišljenje kako je etnonim Shìwéi kasniji oblik naziva Xiānbēi (Нестеров, 1998: 9; Зориктуев, 2011a: 35). Prema E. V. Šavkunovu, etnonim Shìwéi dolazi od imena rijeke Shijiànhé (室建河), pod kojim su u ranome srednjem vijeku bili poznati gornji i srednji tok Amura s pritokama Šilkom i Argunom (Шавкунов, 1968: 26, 32). Kineski povjesničar Zhao Zhan smatrao je da taj etnonim dolazi od mongolske riječi shun, »šuma«, jer su shiweiska plemena uglavnom obitavala u šumskom području (Zhao, 1984: 45).

15 Značenje ovoga etnonima jest »trideset [plemena] Tatara 
sjeveroistok. Autohtono stanovništvo, tungusko-mandžurska plemena Yilóu (挹婁), ušlo je u sastav pridošlih plemena i na kraju asimilirano. Nomadski Xiānbēi donijeli su i promjene u načinu života starosjedilaca, vrlo važnu ulogu počinje dobivati stočarstvo, naročito konjogojstvo. Jedna od važnijih posljedica širenja xianbeiskih plemena bila je promjena etničkog sastava drevnih plemena i pojava novih etnosa. Iz kineskih dinastijskih kronika nestala su imena brojnih plemena, a umjesto njih pojavila su se nova. Tako se u Mandžuriji od 3. do 6. stoljeća pojavljuju Shìwéi, Sùshèn (肅慎), Mòhé (靺鞨) ili Wùjí (勿吉), Wūluòhóu (烏洛侯) ili Wūluóhù (烏 羅護) i drugi (Шавкунов, 1968: 23-25).

Iako je jezgra Shìwéia porijeklom bila povezana s Xiānbēima, taj plemenski savez sadržavao je značajnu tungusko-mandžursku i turkijsku etničku komponentu ${ }^{16}$, i vjerojatno paleosibirske skupine (Асеев, Кириллов і Ковычев, 1984: 135; Билэгт, 2007: 202; Деревянко, 1981: 252, 254; Коновалов, 1989: 16, 18; Нестеров, 1995: 106; Шавкунов, 1968: 26; Тиваненко, 1993: 64; Хu, 2005: 177, 179-180; Зориктуев, 2011a: 35). U povijesnim izvorima Shìwéi se smatraju ogrankom Qìdāna (契丹, sttur. Qïtañ $3 \$ 1 \triangleleft$ ), koji se etnolingvistički ubrajaju u mongolojezična plemena Mandžurije ${ }^{17}$ (Бичурин, 1950: 76; Таскин, 1984: 135-137, 139). Kako je u tradicionalnoj kineskoj historiografiji postojao običaj uopćavanja imena plemena/ naroda koji su imali sličnu kulturu ili su živjeli na određenom prostoru, smatra se da je i etnonim Shìwéi bio uopćeni naziv za plemena različitoga gospodarskoga, kulturnog, lingvističkog i etničkog porijekla. Prema pisanju nekih autora, zapadna shiweiska plemena bila su turkijskoga, središnja xianbeiskog, a istočna tunguskog porijekla (Билэгт, 2007: 182, 202; Нестеров, 1998: 14; Xu, 2005: 177). Od 4. do 6. stoljeća shiweiska plemena živjela su u porječju Amura, do njegova srednjeg toka (Воробьев, 1994: 274), a u razdoblju dinastije Táng (唐 618. - 907.) proširila su se u svim smjerovima - na istok do gorja Mali Hingan ${ }^{18}$ (kin. Xiăo Xīng’ān lǐng 小兴安岭; rus. Малый Хинган), na sjeverozapad do Jablonovskoga gorja ${ }^{19}$

16 Lingvistički su Shìwéi pripadali altajskoj jezičnoj skupini i govorili su proto(mongolskim), turkijskim i tunguskim jezicima (Xu, 2005: 177). Poznati ruski sinolog E. I. Kyčanov smatrao ih je prije svega mongolojezičnim plemenima. Također je ostavio mogućnost da se početkom druge polovine 1. tisućljeća mongolski i tungusko-mandžurski jezici još nisu dokraja razdvojili (Кычанов, 1980: 138).

17 Prema srednjovjekovnim kineskim izvorima, smatraju se potomcima Dōnghúa. Porijeklo im izvode od plemena Xiānbēi. Prve vijesti o njima potječu iz 4. stoljeća, kada su živjeli u južnoj Mandžuriji. Od 5. do 7. stoljeća osnovna masa qidanskih plemena nastanjivala je područje rijeke Šira Mören (kin. Xīlāmùlún 西拉木倫) u Unutarnjoj Mongoliji. Priznavali su vlast sjevernokineskih dinastija, turkijskih naroda (Tūjué, Kök-Turaka, Ujgura) i dinastije Táng. Poput ostalih nomada često su provaljivali u kineske pogranične pokrajine (Sinor, 1998: 227-228, 230).

18 Najvećim dijelom proteže se kroz Mandžuriju, pokrajina Hēilóngjiāng (黑龍江省), a manjim dijelom kroz rusku Amursku oblast (rus. Амурская область).

19 Proteže se kroz središnji dio Zabajkalja. 
(rus. Яблоновый хребет), na jug do rijeke Táorhé20 (洮儿河) i na sjever do gorja Jamalin $^{21}$ (rus. Ям-Алинь) (Зориктуев, 2011a: 36).

Arheološki se plemena Shìwéi identificiraju s burhotujskom kulturom ${ }^{22}$ (rus. бурхотуйская культура), koja je obuhvaćala istočno Zabajkalje, gornji tok Amura i sjeveroistočnu Mongoliju. U istočnom Zabajkalju, prema arheološkim nalazima, shiweiska plemena naseljavala su područje srednjeg i donjeg toka Onona, donji tok Ingode i cijeli tok Argun s njenim lijevim pritokama. Osnovna masa shiweiskog stanovništva zauzimala je porječje Šilke i njenih pritoka. Stanovništvo navedenih područja bavilo se kompleksnim gospodarstvom, koje se sastojalo od poljodjelstva, stočarstva, obrta, lova i ribolova (Allsen, 1994: 329; Асеев, 2009: 189; Асеев, Кириллов і Ковычев, 1984: 125-126; Цыбиктаров, 2001: 189; Коновалов, 1989: 15; Окладников, 1960: 28). Krajem prošlog stoljeća ruski arheolozi izdvojili su još jednu kulturu koja se povezuje s plemenima Shìwéi - mihajlovsku kulturu (rus. михайловская культура). Areal te kulture nalazio se na srednjem toku Amura, u Zejsko-burejskoj nizini, a smješta se u razdoblje od 3. do 7. stoljeća. Etničkim nositeljima te kulture smatraju se sjeverna mongolojezična plemena Shìwéi. Mihajlovska plemena živjela su sjedilački i polunomadski, a gospodarstvo im se sastojalo od poljodjelstva, stočarstva, ribolova i lova (Нестеров, 1995: 117; 1998: 25-52).

U povijesnim izvorima Shìwéi se prvi put spominju 544., kada je njihovo poslanstvo ${ }^{23}$ stiglo na dvor dinastije Istočni Wei. Do razdoblja dinastije Suí (隋 581. - 619.) Shìwéi su se dijelili na pet teritorijalnih ogranaka, poznatih kao Južni Shìwéi (Nán Shìwéi 南室韋) u porječju Nènjiānga ili Nonni, Sjeverni Shìwéi (Běi Shìwéi 北室韋) u porječju gornjeg i srednjeg Amura, Veliki Shìwéi (Dà Shìwéi 大室韋) u porječju Argun ${ }^{24}$, kao i Bō Shìwéi (缽室韋) i Shēnmòdá Shìwéi (深末 怛室韋), vjerojatno u porječju Zeje (Бичурин, 1950: 77; Janhunen, 1996: 184;

20 Rijeka u Unutarnjoj Mongoliji, pritoka Nènjiānga (嫩江).

21 Gorje na ruskom dalekom istoku, na granici Habarovskoga kraja (rus. Хаба́ровский край) i Amurske oblasti.

22 Godine 1960. ruski arheolog A. P. Okladnikov izdvojio je nekropole Burhotuj (rus. Бурхотуй) i Olovjannaja (rus. Оловянная) u porječju Onona u posebnu arheološku kulturu, koju je datirao u 2. - 8. stoljeće. Etničkim nositeljima te arheološke kulture smatrao je »riječne Tatare« Shuǐ-Dádá (水鞋靼) ili »riječne Mongole« Su-Mongal, koje spominju europski poslanici Ivan di Plano Carpini i Willem od Rubrucka (Окладников, 1960: 16-30). Novija arheološka istraživanja od šezdesetih do devedesetih godina datirala su burhotujsku kulturu u 4. - 9. stoljeće, a etnički se pripisuje mongolojezičnim plemenima Shìwéi.

23 Shiweiska poslanstva bila su izvor informacija koje su kineski kroničari zapisali o njima. Od sredine 6. do kraja 9. stoljeća zabilježeno je 57 poslanstava (Нестеров, 1995: 106; Воробьев, 1994: 275).

24 Neki ruski autori locirali su Dà Shìwéi sjevernije, u dijelu Zabajkalja i Jakutije (Деревянко, 1981: 254; Нестеров, 1998: 17; Викторова, 1958: 55). 
Нестеров, 1998: 14-17; Таскин, 1984: 135-136; Воробьев, 1994: 274, 276; Хu, 2005: 173). Početkom 7. stoljeća u savezu je došlo do promjena i izvori govore kako su se Južni Shìwéi »postupno podijelili na dvadeset pet plemena«, dok se Sjeverni Shìwéi »dijele na devet plemena i žive oko planine Tǔgē shān (吐紅山) 《 ${ }^{25}$ (Бичурин, 1950: 77-78; Таскин, 1984: 136-138). U Novoj povijesti dinastije Tang navodi se kako shiweiskih plemena ima »više od dvadeset $« .{ }^{26}$ Shiweiska plemena nisu bila ujedinjena, već je svako pleme imalo svoga starješinu. ${ }^{27}$ Vlast se prenosila po nasljedstvu, a u slučaju nepostojanja nasljednika birali su »jakog i odvažnog«. Takvi tradicionalni plemenski vođe mogli su, u najboljem slučaju, privremeno ujediniti nekoliko plemena (Цыбиктаров, 2001: 191; Васютин, 2010: 23).

\section{SHİWÉI I OKOLNI NARODI}

Zbog političke razjedinjenosti shiweiska plemena priznavala su vlast moćnijih susjeda i plaćala danak. Kada je sredinom 6. stoljeća pao Rouranski Kaganat, na stepi je osnovan Prvi Turski Kaganat (552. - 603.), koji je imao veliki utjecaj na okolne narode. Treći turski kagan Muqan (sttur. JH> kin. Mùgān 木桿 553. - 572,) uspješno je ratovao na istoku u Mandžuriji, gdje je pokorio Qìdāne, a sjevernokineska carstva Běi Qí (北齊 550. - 577.) i Běi Zhōu (北周 557. - 581.) prihvatila su vrhovništvo Kaganata. Najvjerojatnije su tada i Shìwéi, za koje izvor kaže da su »narod siromašan i slab«, potpali pod vlast Turaka, koji su njima vladali »uz pomoć trojice tutuna «28 (Бичурин, 1950: 77; Таскин, 1984: 136). Tako je potkraj 6. stoljeća počeo prodor turkijskih plemena u istočno Zabajkalje i Mandžuriju. O njihovu utjecaju na materijalnu kulturu mjesnog stanovništva informacije nalazimo u arheološkim nalazima. Predmeti, koji se povezuju s materijalnom kulturom turkijskih plemena, najviše se nalaze u pogrebnom inventaru istočnozabajkalskih plemena. Također, široko su bili rasprostranjeni i predmeti vojne uporabe - željezni vrhovi strijela tipičnih turkijskih oblika, pločasti željezni oklopi i konjska oprema (Асеев, Кириллов і Ковычев, 1984: 117-118).

Potkraj 6. stoljeća u Turskom Kaganatu i Kini došlo je do velikih političkih

25 Iako se u izvoru kaže da je bilo devet sjevernih plemena, nabrojeno ih je osam - Lǔngxī Shìwéi ( 嶺西室韋), Shānběi Shìwéi (山北室韋), Huángtóu Shìwéi (黃頭室韋), Dà Rúzhě Shìwéi (大如者 室韋), Xiăo Rúzhě Shìwéi (小如者室韋), Pówō Shìwéi (婆茼室韋), Nèběi Shìwéi (訥北室韋) i Luòtuo Shìwéi (駱駝室韋).

26 Navedena su slijedeća plemena: Wūsùgù (烏素固), Yísāiméi (移塞沒), Sāihézhī (塞曷支), Héjiě (和解), Wūluóhù (烏羅護), Nàlǐ (那禮), Lǐngxī (嶺西), Shānběi (山北), Huángtóu (黃頭), Dà Rúzhě (大如者), Xiăo Rúzhě (小如者), Pówō (婆莒), Nèběi (訥北), Luòtuo (駱駝), Dōng Shìwéi (東室韋), Xī Shìwéi (西室韋), Dà Shìwéi (大室韋), Méngwù Shìwéi (蒙元室韋), Luòzǔ Shìwéi ( 落组室韋) i Dágòujiē (達循接) (Таскин, 1984: 138-139).

27 Izvori shiweiske starješine nazivaju quyyın mòhèduō (乞引莫賀咄) i mòhèfú (莫賀弗) (Бичурин, 1950: 78; Таскин, 1984: 137).

28 Turkijska titula upravitelja oblasti (sttur. tuduy, つ3〉§; kin. Tǔtún 吐屯). 
promjena, koje su utjecale na stanje i odnose u shiweiskom savezu. Nakon smrti Tatpar-kagana (sttur. J'‘n:41今s, kin. Tuóbōkèhán 佗缽可汗 ili Tābōkèhán 他鉢可 汗 572. - 582.) počeli su unutarnji sukobi oko vlasti, a stanje u Kaganatu pogoršala je i strašna glad na stepi. Dugotrajni sukobi završili su 603. raspadom Kaganata na Zapadni Turski Kaganat (603. - 742.) i Istočni Turski Kaganat (603. - 630.; 683. - 745.). U isto vrijeme počeo je proces ujedinjenja Kine. Od 581. do 588. dinastija Suí ujedinila je kineske zemlje i započela reforme koje su gospodarski i vojno osnažile Carstvo. No građanski rat i pad dinastije Suí, koju je zamijenila dinastija Táng, omogućili su privremeno jačanje Istočnoga Turskoga Kaganata. Za vladavine Šibi-kagana (kin. Shǐbì kèhán 始畢可汗 609. - 619.) i Ilig-kagana (sttur. J'‘r:erJr; kin. Jiélì kèhán 頡利可汗 620. - 630.) Istočni Turci ili Kök-Turci (sttur. FrNh::N^) ponovno su počeli napadati pogranične kineske pokrajine. Ali stalni pohodi na Kinu i unutarnje suprotnosti iscrpili su snagu Kaganata. Kako bi zaustavio opasnog susjeda, car Tàizōng (太宗 626. - 649.) sklopio je savez s podanicima Kaganata, plemenima Tiělè2 ${ }^{29}$ i Xuēyántuó (薛延陀) ${ }^{30}$, koji su se pobunili. Godine 629. Iligkagan doživio je poraz u pokrajini Shānxī (山西), a već sljedeće godine kineske vojske osvojile su Kaganat (Christian, 1998: 257-260; Gernet, 1990: 237-238, 252-253; Grousset, 1970: 90, 92-93; Гумилев, 2005: 118-120, 122-126, 150163, 182-196, 205-212, 225-227; Кляшторний, 1995: 61-62; Кляшторний і Савинов, 2005: 91; Sinor, 1990: 305-308; Sinor і Klyashtorny, 1996: 333-334; Wechsler, 1979a: 181-182; 1979b: 220-223).

Uspostavom dinastije Táng znatno je porasla moć Kine, a za vladavine cara Tàizōnga počela je uspješna teritorijalna ekspanzija. Shìwéie i mnoga druga plemena postupno su uvlačili pod svoj politički utjecaj. Od 618. do 629. shiweiska poslanstva redovito su dolazila na carski dvor i donosila danak. Kao odgovor dvor je 629. imenovao činovnika koji je nadgledao plemena Shìwéi i Qìdān. Od pada Istočnoga Turskoga Kaganata do 632. vlast dinastije Táng prihvatili su Wūluóhù i neka shiweiska plemena (Gernet, 1990: 252-253; Таскин, 1984: 138; Хu, 2005: 180-181).

Nakon pada Istočnoga Turskoga Kaganata, pod vodstvom Zhēnzhū-kagana (真 珠可汗 628. - 645.) vlast na stepi preuzela su turkojezična plemena Xuēyántuó. Njihove migracije na istok dovele su ih u susjedstvo Shìwéija. Nakon toga, kao relativno slaba plemena, Shìwéi i Wūluóhù često su bili izloženi napadima, a

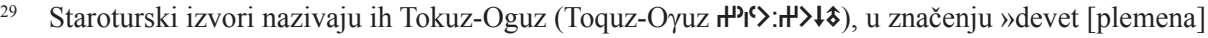
Oguza« (Тугушева, 2008: 131, 145).

30 Bili su u sastavu tieleskoga plemenskog saveza, a staroturski izvori nazivaju ih Sir-Tarduš

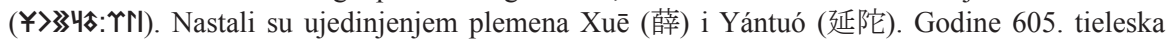

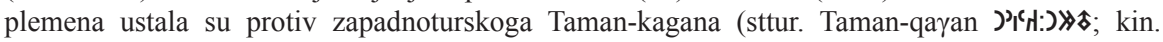
Níjuéchǔluó kèhán 泥厥處羅可汗). Y̌̃shībō (乙失缽), starješina plemena Xuēyántuó, tada je bio proglašen kaganom. On je najprije priznavao vlast Zapadnoga Turskoga Kaganata, a zatim Istočnoga Turskoga Kaganata (Гумилев, 2005: 158-159). 
mnogo pripadnika tih plemena odvedeno je u zarobljeništvo. Napeti odnosi između Kine i Xuēyántuó zbog odnosa prema istočnim Turcima prerasli su 645. u otvoreni sukob, kada je Duōmí-kagan (多爾可汗) napao pogranične pokrajine dok je car bio u pohodu na Koguryŏ. Nakon poraza Xuēyántuó u Kaganatu su nastupili bezvlašće i pobuna pokorenih plemena. Združenim snagama Kinezi, plemena Tiělè i ostali podanici srušili su Kaganat. Najveći dio teritorija Kaganata pripao je Ujgurima

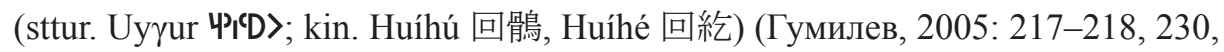
243-245, 249-252; Wechsler, 1979b: 230-231; Xu, 2005: 181).

Pod vodstvom Ilteriš-kagana (sttur. J'‘'d:IYhYY; kin. Jiédiēlìshī kèhán 頡跌利施 可汗 682. - 691.) Kök-Turci su se oslobodili kineske vlasti i na mongolskoj stepi ponovno uspostavili Istočni Kaganat. ${ }^{31}$ Među brojnim neprijateljima Ilteriš-kagana, na jugu Kinezima, na sjeveru turkijskim narodima - Tokuz-Oguzi, Kurikani i Kirgizi

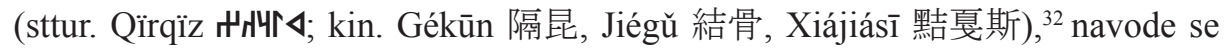
još Otuz-Tatari, Qìdāni i Kùmò Xī (庫莫觅, sttur. Tatabï \S\$s) ${ }^{33}$ (Гумилев, 2005: 308; Малов, 1951: 38; Тугушева, 2008: 41). Najveća opasnost za novoosnovani kaganat bila su tieleska plemena, koja su predvodili Tokuz-Oguzi. Nakon poraza na rijeci Tuul u središnjoj Mongoliji, vođe tieleskih plemena bili su prisiljeni pokoriti se i priznati vrhovnu vlast kagana, koji je tako učvrstio vlast na stepi. Pod turskim pritiskom kod shiweiskih plemena pojavile su se prve naznake udaljavanja od dinastije Táng (Xu, 2005: 181). Mirne odnose s Kinom želio je uspostaviti Kapagan-

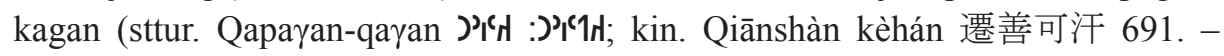
716.), koji je Carstvu pomogao da pobijedi pobunjene Qìdāne, ali kada se počeo miješati u poslove dvora, izbio je sukob. U daljnjem tijeku događaja Kök-Turci su u Mandžuriji pokorili plemena Qìdān, Shìwéi i Kùmò Xī. Godine 707. shiweisko poslanstvo stiglo je na carski dvor i predložilo sklapanje saveza protiv Kök-Turaka (Таскин, 1984: 141). Nakon krize Kaganata zbog sukoba oko vlasti, kineski car Xuánzōng (玄宗 712. - 756.) odlučio je uništiti Kaganat. Godine 720. carska vojska i saveznici - Basmili ${ }^{34}$ (sttur. Basmïl J»SS; kin. Báxīmì 拔悉密), Qìdāni i Kùmò

31 Kod nekih autora ta se država naziva Drugi Turski Kaganat.

32 Od 5. do 6. stoljeća obitavali su na srednjem Jeniseju u Minusinskoj kotlini. U izvorima područje naseljeno Kirgizima naziva se Qìgǔ (契骨) ili Gēgǔ (紇骨). Sredinom 6. stoljeća priznali su vlast Prvoga Turskoga Kaganata, zatim Xuēyántuó i Drugoga Turskoga Kaganata, a sredinom 8. stoljeća Ujgura. Arheološka kultura Kirgiza 6. - 9. stoljeća naziva se Čaa-tas (rus. Чаa-тас) (Бутанаев і Худяков, 2000: 57-65; Кляшторный і Савинов, 2005: 252-257).

33 Kùmò Xī ili X̄̄ (觅), mongolojezično pleme, koje se u kineskim izvorima uglavnom smatra potomcima plemena Dōnghú. Živjeli su u Mandžuriji, na padinama gorja Hingan. Na zapadu su graničili s Turcima, a na istoku s Qidānima. Priznavali su vlast dinastije Táng i Turaka. Krajem 9. stoljeća veliki dio Kùmò X̄̄ potpao je pod vlast Qìdāna, dok je manji dio priznao kinesku vlast. U 11. stoljeću najvećim dijelom asimilirali su ih Qìdāni.

34 Turkojezično pleme koje se u izvorima prvi put spominje u razdoblju dinastije Suí. Nastanjivali su prostor Džungarije. Priznavali su vlast Turaka, dinastije Táng, Ujgura i Karluka. U drugoj polovini 
Xī, krenuli su iz raznih smjerova prema kaganovu dvoru. Ali Bilge-kagan (sttur. ’’n:SEYYR; kin. Píjiākèhán 毗伽可汗 716. - 734.) pojedinačno je uspio pobijediti kineske saveznike. Nakon toga je put u Kinu bio otvoren i car je morao pristati na zaključivanje mira. Nekoliko godina poslije Kök-Turci su pobijedili pobunjena tieleska plemena i Tatare. Urušavanje Istočnoga Kaganata počelo je ubrzo nakon smrti Bilge-kagana. U to doba, 742., u Kini je energični Xuánzōng proveo uspješnu vojnu reformu i osnovao deset pograničnih vojnih oblasti jiédù (节度). Za obranu od Kök-Turaka ustrojene su oblasti Héxī (河西), Shuòfāng (朔方) i Hédōng (河 東), za obranu od Qìdāna i Kùmò Xī oblast Fànyáng (范陽) i za obranu od Shìwéia i Mòhé oblast Pínglú (平盧). ${ }^{35}$ Zbog vojnog jačanja Kine sve je više shiweiskih plemena počelo priznavati carsku vlast i donositi danak, ali i istovremeno u savezu s Turcima povremeno napadati kineske pogranične oblasti (Xu, 2005: 181). Na poticaj iz Kine u Kaganatu je 742. počela pobuna Ujgura, Basmila i Karluka ${ }^{36}$ (sttur.

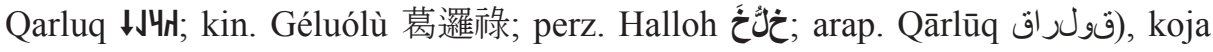
je završila padom Istočnoga Kaganata i političkom prazninom na stepi. Uskoro je među pobjednicima počela borba za vlast nad ostacima turkijskih plemena i titulom kagana, u kojoj su pobijedili Ujguri (Christian, 1998: 261-263; Golden, 1992: 136-138; Гумилев, 2005: 296-305, 308-310, 314-318, 331, 340, 348-350, 358, 397-402; Камалов, 2001: 68-75; Кляшторний і Савинов, 2005: 101, 110; Sinor, 310-313; Sinor i Klyashtorny, 1996: 335, 338-341; Sinor, Shimin i Kychanov, 1998: 192; Twitchett, 1979: 435-438; Twitchett i Wechsler, 1979: 286-289).

U razdoblju Ujgurskoga Kaganata (744. - 840.) plemena Shìwéi periodično su priznavala vlast Ujgura i dinastije Táng. Prema nekim autorima, Tatari i Qìdāni ${ }^{37}$ pridružili su se pobuni protiv ujgurskog Eletmiš Bilge-kagana (sttur.

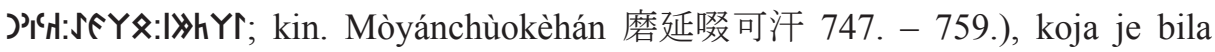
ugušena. Nakon konsolidacije vlasti kagan je ujesen 750 . pokorio Tatare u sjeverozapadnoj Mandžuriji (Гумилев, 2005: 408-410; Taşağil, 2002: 415-416). Na sjeveru Kine ustanak generala Ān Lùshāna (安祿山) 755. izazvao je velika previranja i ozbiljno ugrozio položaj dinastije Táng. Ān Lùshānu pridružila su se

9. stoljeća bili su potisnuti u današnji jugoistočni Kazahstan, povijesnu pokrajinu Sedmorječje (kaz. Жетісу; rus. Семиречье).

35 Zapovjedništvo vojne oblasti Pínglú nalazilo se u suvremenoj pokrajini Liáoníng (遼寧) na jugu Mandžurije.

36 U povijesnim izvorima pojavljuju se u prvoj polovini 7. stoljeća. Pripadali su plemenskom savezu Turgeš (sttur. Türges IF YrNh; kin. Tūqíshī 突騎施), koji je vladao Zapadnim Turskim Kaganatom. Nastanjivali su porječje Crnog Irtiša i gorja Tarbagataj, na granici Kazahstana i Kine. Nakon poraza od Ujgura 746. migrirali su u Sedmorječje, gdje su osnovali Kaganat.

37 Drugačije mišljenje iznosi Kamalov. Prema njemu, riječ je o turkojezičnim plemenima Sekiz-Oguz

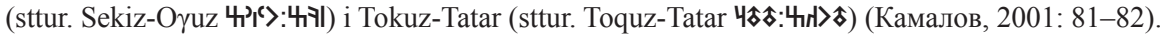


plemena Shìwéi, Tóngluó ${ }^{38}$ (同羅, sttur. Tongra 24ఛ〉§), Kùmò X̄̄ i Qìdāni. Ali već u razdoblju vladavine Dàli39 (大曆 766. - 779.) Shìwéi su ponovno priznavali vlast Carstva. Izvori govore o jedanaest shiweiskih poslanstava, koja su redovito donosila danak na carski dvor. Također i tijekom razdoblja 792. - 840., dok su bili ujgurski vazali, Shìwéi su donosili danak na carski dvor. Početkom 9. stoljeća borbe za prijestolje, neuspjeh u ratu protiv Tibeta i pobuna Kirgiza oslabili su Ujgurski Kaganat. Inicijativu na stepi tada su počeli preuzimati Kirgizi, koji su 840. osvojili Kaganat. Nakon pada Kaganata slijedile su migracije ujgurskih plemena, od Istočnog Turkestana do Zabajkalja, a dio je prodro u Mandžuriju i nastanio se na shiweiskom području uz gorje Veliki Hingan. Ipak, znatni dio Ujgura ostao je na mongolskim stepama i poslije ušao u sastav Mongola. Imali su važnu ulogu u razvoju mongolskog jezika, klasičnoga mongolskog pisma ${ }^{40}$ i kulture (Бутанаев i Худяков, 2000: 74-78; Цэвээндорж et al., 2008: 180; Drompp, 2002: 482-483; Golden, 1992: 162-163; Худяков, 1993: 167; Нестеров, 1998: 100; Савинов, 1994: 47-48; Sinor, Shimin i Kychanov, 1998: 196; Таскин, 1984: 139, 141; Васютин, 2010: 23; Xu, 2005: 182-183).

Veliki utjecaj na plemenski savez Shìwéi imali su i Hēishuǐ Mòhé (黑水靺鞨). Priamurje se do kraja 7. stoljeća dijelilo na dva etnokulturna entiteta - zapadno Priamurje naseljavala su mongolojezična plemena Běi Shìwéi, a istočno Priamurje i područje između rijeka Sungari i Usuri sjeverna tunguzojezična plemena Hēishuǐ Mòhé. ${ }^{41}$ Granica među njima bilo je gorje Mali Hingan. Na prijelazu iz 6. u 7. stoljeće politički procesi u Mandžuriji pokrenuli su migracije dijela Hēishuǐ Mòhé u zapadno Priamurje. U to doba druga skupina tunguskih plemena Sùmò Mòhé (栗末靺鞨) ${ }^{42}$ osnovala je kraljevstvo Bóhăi (渤海 698. - 926.). Bohajski vladar Wǔ-wáng (武王 719. - 737.) vodio je brojne pohode koji su »značajno proširili zemlju i nebo na sjeveroistok«. Protiv sjevernih plemena osvajačke pohode vodio je i Dà Rénxiù (大仁秀 818. - 830.), koji je također proširio teritorij kraljevstva. Među poraženim sjevernim plemenima, nesumnjivo, bili su i Hēishuǐ Mòhé. Nakon prodora u zapadno Priamurje oni su pokrenuli migracije Běi Shìwéi i jezičnu

38 Pleme iz saveza Tiělè. Prvotno su nastanjivali područje uz rijeku Tuul u sjevernoj Mongoliji.

39 Posljednje razdoblje vladavine cara Dàizōnga (代宗 762. - 779.) iz dinastije Táng.

40 U kronici Povijest dinastije Yuan (Yuánshř 元史), sastavljenoj u drugoj polovini 14. stoljeća, osnivačem mongolske pismenosti smatra se Tătătǒngā (塔塔統阿). Taj učeni Ujgur nakon pada u mongolsko zarobljeništvo dobio je od Džingis-kana zadatak da poučava pisanje na ujgurskom pismu (Christian, 1998: 398; Grousset, 1970: 216; Janhunen, 1996: 160; Кадырбаев, 1984: 255; Викторова, 1980: 175).

${ }^{41}$ Ime su dobili od naziva rijeke Hēishuľ, kako se u kineskim izvorima nazivao donji tok Amura nakon ulijevanja rijeke Sungari u njega. Arheološki se identificiraju s najfeldskom kulturom (rus. найфельдская культура).

42 Nastanjivali su gornji tok rijeke Sungari, koja se u kineskim izvorima nazivala Sùmò. 
asimilaciju dijela mongolojezičnih starosjeditelja. Prema S. P. Nesterovu, dio Běi Shìwéia migrirao je sjevernije na područje koje su nastanjivali Bō Shìwéi. U drugoj polovini 8. pa do 9. stoljeća i dio Sùmò Mòhé migrirao je u Priamurje ${ }^{43}$ (Нестеров, 1995: 106, 110, 112-113; 1998: 20-24, 52, 67-70, 75, 94-95; 2002; Шавкунов, 1968: 30, 32-33, 41; Воробьев, 1994: 111-117, 135).

Na kraju 9. stoljeća, kada je u Kini i na stepi došlo do sloma središnje vlasti, u Mandžuriji je počeo politički uspon Qìdāna. Taj proces započeo je qidanski starješina Xíěrzhī (習爾之) u razdoblju vladavine Xiántōng (咸通 860. - 874.). ${ }^{44}$ Sljedeći qidanski starješina Qīndé (欽德), u razdoblju vladavine Guāngqǐ (光啟 885. - 888.), ${ }^{45}$ napao je plemena Shìwéi i Kùmò X̄̄ , dok su ostala manja plemena priznala njegovu vlast. Uskoro su Qìdāni pokorili pet klanova Kùmò Xī i sedam klanova Shìwéia. Najveće uspjehe postigao je qidanski vođa Ābăojī (阿保機 872. 926.). On je najprije primorao na predaju pleme Xiăo Huáng Shìwéi (小黃室韋), a 901. porazio je plemena Yújué (于厥), ${ }^{46}$ Shìwéi i Kùmò Xī. Od 904. do 907. Ābăojī je na sjeveru vodio pohode na Hēichēzi Shìwéi (黑車子室韋), koji su završili uključivanjem potonjih u qidanski plemenski savez. Osim pokoravanja shiweiskih plemena veliki pritisak Qìdāna izazvao je njihove migracije na zapad i istok. Od početka 10. do kraja 13. stoljeća shiweiska plemena postupno su asimilirali okolni narodi - Qìdāni, Džurčeni ${ }^{47}$ (džur. Jušen 重济; kin. Jìzhēn 稷真, Nǔzhēn 女眞, Nŭzhí 女直, Nüzzhì 女質, Lüzhēn 慮真; mong. Jürchin), Mongoli i Kinezi (Думан, 1986: 14; Е Лун-ли, 1979: 41-42, 332; Franke, 1990: 403; Гумилев, 2004: 6364; Sinor, 1998: 229; Таскин, 1984: 171-172; Twitchett i Tietze, 1994: 53-59; Викторова, 1980: 142; Wittfogel i Fêng, 1949: 528; Xu, 2005: 183).

43 Drugi val migracija moheskih plemena arheološki se identificira $\mathrm{s}$ troickom kulturom (rus. троицкая культура).

44 Razdoblje vladavine cara Yìzōnga (懿宗) iz dinastije Táng.

45 Pretposljednje razdoblje vladavine cara Xīzōnga (僖宗 873. - 888.) iz dinastije Táng.

46 Živjeli su sjeverozapadno od Qìdāna, u istočnoj Mongoliji. U povijesnim izvorima nazivaju se Wūgǔ (烏古), Wūgǔlǐ (鳥古里), Yǔjué (羽厥) i Yùjuélü (嫗厥律). Neki autori smatraju ih precima mongolskog plemena Onggirat ili Unggirat (kin. Hóngjílà 弘吉刺,Wángjilà 王紀刺, Guăngjílà 廣 吉刺, Yōngjíliè 雍吉烈).

47 U kineskim kronikama smatraju se potomcima drevnih tunguskih plemena Sùshèn i Mòhé, nastanjenih u zemlji Dōngběi (東北) - Mandžuriji. Krajem 6. stoljeća počeli su plaćati danak dinastiji Suí. U narednim stoljećima priznavali su vrhovništvo dinastije Táng i redovito plaćali danak. Kineski zapisi iz razdoblja Pet dinastija (907. - 960.) počinju ih nazivati Nŭzhēn (Кычанов, 1966: 271-272). 


\section{POČETNO RAZDOBLJE POVIJESTI MONGOLA}

Kako smo već naznačili, u shiweiskom savezu mongolojezičnu komponentu činili su Běi Shìwéi, potomci sjevernih Xiānbēia koji su se nastanili u istočnom Zabajkalju i na gornjem toku Amura. Dinastijske kronike Stara povijest dinastije Tang i Nova povijest dinastije Tang među Běi Shìwéima navode pleme Méngwù ili Méngwă (蒙瓦), ${ }^{48}$ koje mnogi autori smatraju prvim vjerodostojnim zapisom etnonima Mongol (Allsen, 1994: 329; Bira, 1998: 243; Golden, 1992: 283; Hambis, 1970: 126; Jackson, 2009: 26; Кычанов, 1980: 136, 138; Кычанов, 1966: 270; 1997 : 174-175; Кляшторный і Султанов, 2009: 210; Нестеров, 1998: 101; Ratchnevsky, 1991: 7; Таскин, 1984: 139, 141; Викторова, 1980: 156; Weiers, 1997: 27-28; Хu, 2005: 175; Зориктуев, 2011a: 22, 36). Prema rekonstrukciji francuskog sinologa L. Hambisa, etnonim Méngwù čitao se *Mung-nguət (Hambis, 1970: 126). Poput većine shiweiskih plemena i Méngwù su obitavali u šumskom području, sjevernije od stepe. Živjeli su sjedilački i polunomadski, a gospodarstvo im se sastojalo od lova, ribolova, poljodjelstva i stočarstva. Lingvistička istraživanja pokazala su kako osobno mongolski leksik za domaće životinje postoji samo za psa, konja ${ }^{49}$ i svinju, ali ne i za životinje vezane uz nomadsko stočarstvo, dok za divlje životinje postoje nazivi za šumske životinje (npr. sjeverni jelen, divlja svinja) i krupne riječne ribe. U tome ranom »šumskom razdoblju« svoje povijesti drevni Méngwù stanovali su osim u šatorima i u trajnim nastambama, ${ }^{50}$ karakterističnim za lovce i ribolovce Priamurja (Асеев, 2009: 190; Clauson, 1973: 41; Golden, 2009: 19; Кызласов, 1975: 171, 173; 1992: 134, 137, 149-152; Щербак, 1966: 30). Nedavna genetička istraživanja, koja dokazuju blisku srodnost većine mongolskih etničkih skupina s populacijama na sjeveru istočne Azije, ${ }^{51}$ dodatno su potvrdila tezu o Mandžuriji kao "pradomovini« Mongola (Деренко et al., 2004: 1563; Katoh et al., 2005: 67, 69).

Krajem 6. i početkom 7. stoljeća iz porječja Lene migrirala su na gornji Amur plemena Dà Shìwéi, ${ }^{52}$ gdje su se sukobili s mongolojezičnim shiweiskim plemenima. Te su migracije izazvale velike promjene u etničkom sastavu

48 Francuski sinolog P. Pelliot i njemački sinolog P. Ratchnevsky smatrali su kako se oblik Méngwă u Novoj povijesti dinastije Tang pojavio zbog pogreške u prijepisu. Izvori iz kasnijeg razdoblja, 12. - 14. stoljeće, bilježe etnonim u različitim oblicima: Mánggǔzi (盲骨子), Ménggǔzi (萌骨 子), Mánghuōlēi (忙豁勒), Ménggǔ (朦古), Ménggǔ (蒙骨), Ménggǔ (萌古), Ménggǔ (萌骨), Méngguó (蒙國), Měnggǔsī (蒙古斯), Měnggǔlǐ (蒙古里) itd. (Hambis, 1970: 127; Serruys, 1982: 475-476; Tamura, 1973: 6-11; Зориктуев, 2011b: 53).

49 Preci Mongola prvotno su uzgajali konje zbog mesa, a poslije za jahanje (Кызласов, 1975: 171).

50 Prema L. R. Kyzlasovu, Mongoli su euroazijskom stepom proširili karakterističnu kvadratnu nastambu, koja je nastala još u »šumskom razdoblju« njihove povijesti (Кызласов, 1975: 173-174).

51 Većina mongolske populacije ima visok udio haplogrupa $\mathrm{C}^{*}(\mathrm{xC} 3 \mathrm{c})$ i $\mathrm{C} 3 \mathrm{c}$, karakterističnih za Mandžurce i Korejce.

52 Nesterov smatra Dà Shìwéi sjevernim tunguskim plemenima (Нестеров, 1995: 113; 1998: 52). 
stanovništva toga područja. Starosjedioce Běi Shìwéi potisnuli su Wūhuáni ( 烏桓), koji su se premjestili s gornjeg Amura istočnije od planina Mali Hingan. Drugi dio gornjoamurskog stanovništva, plemena Méngwù i Luòzǔ Shìwéi, prodor novopridošlih skupina podijelio je na dva dijela, potisnuvši ih na istok, odakle su migrirali u porječje Argun (Нестеров, 1995: 112; 1998: 19, 101). Spomenute kineske dinastijske kronike također smještaju pleme Méngwù na rijeku Argun, ${ }^{53}$ koju nazivaju Wàngjiànhé (望建河) i Shìjiànhé (室建河) (Кычанов, 1997: 175; Таскин, 1984: 139, 141, 362). Početkom 14. stoljeća perzijski povjesničar Rašīduddīn (نبيدلا ديشر) u svom glasovitom djelu Opća povijest (Džāmi ul-tavārih piše kako su preci Mongola prije izlaska na stepu boravili u području zvanom Ergune-kun. ${ }^{54}$ Prema Rašīduddīnu, »... kod toga plemena, koje su u davnini nazivali Mongol, započela je svađa s drugim turskim plemenima, koja je završila sukobom i ratom. Postoji predaja (...) da su druga plemena pobijedila Mongole i među njima počinila takav pokolj da su ga preživjela samo dva muškarca i dvije žene. Te dvije obitelji u strahu pred neprijateljem pobjegle su u nepristupačno područje, koje je sa svih strana bilo okruženo planinama i šumama i prema kojem ni s jedne strane nije bilo puta (...) Između tih planina nalazila se stepa bogata travom i klimatski zdrava. Ime toga područja jest Ergune-kun (...) A imena tih dvoje ljudi bila su Nukuz i Kiyan. Oni i njihovi potomci zadržali su se godinama na tom području i razmnožili« (Рашид ад-Дин, 1952, I, 1: 153). Pradomovinu Mongola, Ergune-kun, istraživači najčešće identificiraju s porječjem Argun, a najpreciznije su njezin položaj odredili S. P. Nesterov - donji tok, prije spajanja sa Šilkom, i B. R. Zoriktuev - visoravan u čijoj se blizini rijeka Jīliúhé (激流河) ulijeva u Argun ${ }^{55}$ (Нестеров, 1998: 19; Зориктуев, 2009: 128; 2011b: 54-55). U to doba drevni Mongoli priznavali su vlast turkijskih naroda koji su vladali stepom i osnovali moćne države - Drugi Turski Kaganat i Ujgurski Kaganat. Sjeverna mongolska plemena održavala su bliske odnose s tunguskim plemenima, koja su naseljavala šumska područja na sjeveru i istoku (Викторова, 1980: 165).

53 Rijeka Argun (mong. Ergüne; kin. É’ěrgǔnàhé 額爾古納河) gornjim tokom protječe kroz Unutarnju Mongoliju. Velikim dijelom toka čini granicu između Rusije i Kine. Nakon spajanja s rijekom Šilkom nastavlja se kao rijeka Amur.

54 Kod Rašīduddīna je značenje tog toponima »strma padina« ili »strma planina«. T. D. Skrynnikova izvela je etimologiju toga toponima iz tungusko-mandžurskih jezika, u kojima riječ kun znači »zemlja«. Novo objašnjenje toponima jest »zemlja u porječju rijeke Argun« (Рашид ад-Дин, 1952, I, 1: 153; Скрынникова, 2005: 63).

55 Neki suvremeni autori koji su istraživali smještaj Ergune-kuna došli su do drugačijih zaključaka. Tako u mongolskoj historiografiji postoji mišljenje da se Ergune-kun nalazila u gorju Tannu-Urjanha u južnoj Tuvi. Burjatski znanstvenici S. Š. Čagdurov i P. B. Konovalov mongolsku pradomovinu smještaju u zapadnu Burjatiju, uz granicu s istočnom Tuvom, a A. L. Angarhaev u Sajansko gorje (Ангархаев, 2003: 21-23, 112-115, 139; Чагдуров, 1999: 93-128; Коновалов, 1999: 123-128, 131; Зориктуев, 2011а: 10). 
Uz Ergune-kun povezano je još jedno važno pitanje mongolske povijesti etnonim Mongol. Vrijeme nastanka etnonima Mongol ne može se točno odrediti. Burjatski filolog S. Š. Čagdurov smatra da je nastao najkasnije do kraja 8. stoljeća (Чагдуров, 1999: 110), u doba kada su preci Mongola još uvijek živjeli na Argunu. Najnoviju etimologiju etnonima Mongol dao je B. R. Zoriktuev. Prema njemu, rod Činō i rodove proizašle od njih susjedna tunguska plemena su nazvala Mangol, prema mjestu prebivanja svoga vođe, dolini rijeke Mangu. ${ }^{56}$ Etnonim Mangol

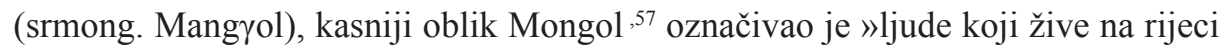
Mangu« (Зориктуев, 2009: 126, 129-130; 2011a: 22, 41-42; 2011b: 55-56).

Vidjeli smo kako B. R. Zoriktuev smatra da je drevni mongolski rod Činō nastao miješanjem Róurána i shiweiskih plemena. U kronici Raš̄iduddīna spominje se rod Činō, ali pod nazivom Nukuz, izvedenom od mongolske riječi noxai, "pas« ili »vuk» (Рашид ад-Дин, 1952, I, 2: 25; Сухбаатар, 1996: 71; Зориктуев, 2003: 46). Također, u historiografiji postoji mišljenje o turkijskom porijeklu roda Činō (Коновалов, 1999: 83), a sličnu tezu zastupala je i L. L. Viktorova. Prema njoj, poslije pada Istočnoga Turskoga Kaganata (630.) veliki dio Turaka priznao je vlast dinastije Táng. Nakon nekog vremena, pod vodstvom Āshǐnà Sīmó (阿史那思 摩), dio njih migrirao je na sjever u istočnu Mongoliju, gdje su osnovali etnički heterogeni, turkijsko-mongolski vladajući rod (Викторова, 1980: 157-158).

Najstarija mongolska kronika Tajna povijest Mongola (mong. Mongyol-un

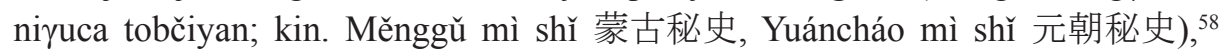
u kojoj je zapisana genealogija mongolske vladarske obitelji, počinje predajom o Modro-sivom Vuku (mong. Börte-Činō; kin. Bèiértiē chìnà 孛児帖赤那) i Bijelo-žutoj Košuti (mong. Qo’ai-Maral; kin. Huōāi mălánlēi 中豁埃馬舌闌勒) (Allsen, 1994: 330; de Rachewiltz, 1997: 153-155; 2004, 1: 1; Козин, 1941: 79; Зориктуев, 2010a: 136-139). U starijoj historiografiji Börte-Činō smatrao se stvarnom povijesnom osobom i navodno je živio sredinom 8. stoljeća (Викторова, 1980: 156). No u novijim radovima prihvaćeno je mišljenje o totemističkom karakteru prvopredaka, s jasnim etničkim obilježjima - Börte-Činō, personifikacija

56 Zoriktuev ime rijeke izvodi iz tungusko-mandžurskih riječi mangmu/manggu/mangga - »snažan, čvrst, tvrd«. Kasniji kineski naziv Jīliúhé u prijevodu označuje »brzu, divlju rijeku«. Kod Rašīduddīna mongolski je naziv za tu rijeku Kiyan (Рашид ад-Дин, 1952, I, 1: 154; Зориктуев, 2010b: 97, 98).

57 O etimologiji etnonima Mongol u europskoj historiografiji prvi je pisao Isaac Jacob Schmidt (1779. - 1847.), ruski orijentalist njemačkog porijekla. Pregled teorija o etimologiji i porijeklu imena Mongol vidi u Ангархаев, 2003: 9-23; Зориктуев, 2011: 22-34; 2011a: 48-50.

58 Izvorna verzija te kronike, najvjerojatnije napisana ujgurskim pismom, nije se sačuvala. U historiografiji prevladava mišljenje da je sastavljena 1240. Iako je autor kronike anoniman, neki znanstvenici kao mogućeg autora navode Šigi Kutukua (mong. Šigi Qutuqu; kin. Shījí Hūtūhū 失吉忽秃 忽), Džingis-kanova posinka. U prvoj polovini 15. stoljeća, u razdoblju dinastije Míng (明 1368. - 1644.), sastavljen je kineski prijevod kronike. 
mongolskih rodova/plemena, dok je Qo'ai-Maral personifikacija turkijskih rodova/plemena (Коновалов, 1999: 61, 96, 106, 118; Зориктуев, 2003: 44, 45, 49; Зориктуев, 2010a: 137, 138; 2011a: 12-16). Tako je po genealogijskoj liniji najstariji Džingis-kanov predak, za kojega možemo pretpostaviti da je stvarna povijesna osoba, Batači-kan (mong. Batačiqan; kin. Bātăchìăn 巴塔赤中罕) iz druge polovine 8. stoljeća, koji je živio na gornjem toku rijeke Onon.

O tome kada su Mongoli počeli migrirati iz Ergune-kuna ${ }^{59}$ u historiografiji postoje različita mišljenja, koja se odnose na razdoblje od kraja 7. do 11. stoljeća. Kao uzrok migracija obično se navode krupni politički događaji na stepi - ratovi shiweiskih plemena sa susjednim narodima, pad Istočnoga Turskoga Kaganata 742. (Ангархаев, 2003: 47, 53, 110; Кычанов, 1997: 177; Зориктуев, 2011a: 49, 53, 64) i širenje carstva Qìdāna početkom 10. stoljeća (Кызласов, 1975: 170; 1992: 148, 156). Te migracije bile su postupne i dugotrajne, a posljednje skupine napustile su Ergune-kun krajem 11. stoljeća pod pritiskom Džurčena. Osim vladajućeg roda Činō iz »pradomovine« su migrirali brojni drugi rodovi i plemena. Prema Rašīduddīnu, rodovi i plemena koji su potjecali od ostataka plemena Nukuz i Kiyat, koji su migrirali iz Ergune-kuna, nazivaju se Mongoli-Darlekini i u njih se ubrajaju Arulati, Baya'uti, Eljigeni, Husini, Ikiresi, Ildürgini, Kingqiyati, Nukuzi, Olqunu'uti, Oriyati, Oriyat-Kilungquti, Qaranuti, Qonqirati, Qonqotani, Qorolosi, Suldusi i Uriangqai (Ангархаев, 2003: 39, 53; Рашид ад-Дин, 1952, I, 1: 78, 152; Rybatzki, 2006: 135; Скрынникова, 2005: 47; Зориктуев, 2011a: 49, 63).

Dolazak mongolskih rodova/plemena u stepe današnje Mongolije datira se $u$ drugu polovinu 10. pa do početka 11. stoljeća (Allsen, 1994: 329-330; Кычанов, 1980: 141; Зориктуев, 2011a: 49, 63). No pitanje smjera migracija u literaturi nije dokraja razjašnjeno i ono ovisi o tumačenju pojma Tenggis (kin. Téngjísī 騰波思) iz prvog paragrafa Tajne povijesti Mongola, gdje se kaže da su Börte-Činō i Qo'aiMaral na svom putu prešli Tenggis i stigli na izvor rijeke Onon (de Rachewiltz, 2004, 1: 1; Козин, 1941: 79). ${ }^{60}$ Burijatski povjesničari B. R. Zoriktuev i P. B. Konovalov pod pojmom Tenggis podrazumijevaju Bajkalsko jezero. Ukratko, Zoriktuevljeva migracijska shema glasi: do kraja 8. stoljeća rod Činō migrirao je s rijeke Argun najprije na zapadnu obalu Bajkalskog jezera, a otuda na istočnu

\footnotetext{
Legendu o izlasku Mongola iz Ergune-kuna zapisao je Rašīduddīn. Kada se narod razmnožio, prostor Ergune-kuna postao im je pretijesan i nepovoljan za daljnji boravak. Zato su odlučili napustiti to područje. Na mjesto gdje su nekada vadili željeznu rudu i talili željezo donijeli su velike količine drva i ugljena. Od koža sedamdeset bikova i konja napravili su kovačke mjehove, kojima su rasplamsali vatru i rastalili strminu. Tako su dobili veliku količinu željeza, a otvorio se i prolaz za izlazak na stepu (Рашид ад-Дин, 1952, I, 1: 154).

60 Cijeli tekst glasi: »Na početku je bio modro-sivi vuk, čija je sudbina bila predodređena od samih nebesa. Njegova žena bila je ženka jelena. Došli su prelazeći Tenggis. Nakon što su se nastanili na izvoru rijeke Onon na planini Burkan Kaldun, rodio im se Batači-kan« (de Rachewiltz, 2004, 1: 1; Козин 1941: 79).
} 
obalu jezera, u Barguzinsku dolinu i okolna područja zapadnog Zabajkalja. Poslije odlaze u Mongoliju, na gornji tok rijeke Onon, gdje su, okupivši oko sebe druga plemena, formirali jezgru srednjovjekovnih Mongola (Коновалов, 1999: 126, 128, 131; Зориктуев, 2003: 49, 53-54; 2010b: 98; 2011a: 42-43, 51-52, 54; 2011b: 56). Japanski povjesničar J. Tamura i E. I. Kyčanov pod pojmom Tenggis podrazumijevali su jezero Hūlún (Hūlún hú 呼倫湖; mong. Hölön nuur ili Dalaj nuur). ${ }^{61}$ Prema Tamuri, krajem 10. i početkom 11. stoljeća počela je migracija Mongola s rijeke Argun, teritorija na kojemu su živjeli u razdoblju dinastije Táng. U prvoj polovini 12. stoljeća prešli su jezero Hūlún i stigli na donji i srednji tok Onona, gdje su prihvatili nomadski način života. O tim događajima govori predaja o Bodončaru iz Tajne povijesti Mongola (Кычанов, 1980: 139; Tamura, 1973: 13).

Mongoli i njima srodni rodovi/plemena Urjanhaj (mong. Uriangqai; kin. Wùliánghái 元良孩, Wòlănggăi 斡朗改), Tajčut (mong. Tayyiči’ut; kin. Tàichìwùtì 泰赤元惕), ${ }^{62}$ Džalajir (mong. J̌alayir, J̌ăiradai; kin. Zhálàyìr 札刺亦兒, Zhálàyilún 札刺亦侖 ${ }^{63}$ i drugi nastanili su područje Trorječja - gornji tok Onona, Kerulena i Tuula. Prema E. I. Kyčanovu, Mongoli su nastanjivali donji i srednji tok Onona, donji tok Kerulena i zapadne ogranke Hingana, gdje su graničili s Džurčenima. Krajem 10. stoljeća plemena Trorječja osnovala su savez, koji je vodio Bodončarmungkag (mong. Bodončar-mungqaq; kin. Bèiduāncháér-ménghéhēi 孛端察児 蒙中合黒), osnivač roda Bordžigin. ${ }^{64}$ Dvanaest generacija mongolska plemena

${ }^{61}$ Jezero na sjeveroistoku Unutarnje Mongolije.

62 Prema podacima iz kronike Rašīduddīna, rod/pleme Tajčut pripadalo je među Mongole-Nirune, potomke mlađih sinova legendarne Alan-qo'a. Neposrednim osnivačima u Tajnoj povijesti Mongola navode se Senggüm-bilge (kin. Xiăngkūn bilēigé 想昆必勒格) i Ambakaj-kan (mong. Ambaqai-qahan; kin. Ǎnbāhái-héhăn 俺巴孩中合罕), sinovi Čarahaj-linhua (mong. Čaraqai-lingqu; kin. Chálàhái lǐnghū 察舌刺孩領中忽). Postoji i mišljenje kako je etnonim izveden od kineske titule tàiž̌ (太子) - »princ, nasljednik prijestolja« (de Rachewiltz, 2004,1: 9; Козин, 1941: 83; Рашид ад-Дин, 1952, I, 1: 78, 180).

${ }^{63}$ Neki autori smatraju da su bili mješovitoga turkijsko-mongolskog porijekla. Kazahstanski povjesničar K. Z. Uskenbaj smatra ih potomcima turkijskih Ujgura koji su nakon pada Kaganata priznali vlast Qìdāna, a etnonim izvodi od imena ujgurskoga vladajućeg roda Jaylaqar (sttur. 4NI's'D; kin. Yàoluógé 藥羅葛). U Povijesti dinastije Liao nazivaju se Zǔbǔ Zhálà (阻卜札刺). Krajem 11. stoljeća doživjeli su težak poraz od carstva Liáo. U mongolskom razdoblju osnovna skupina Džalajira nastanjivala je teritorij uz rijeku Kerulen. Rašīduddīn ih ubraja među Mongole-Darlekine, plemena koja su se nakon nastanka Mongolskog Carstva počela nazivati Mongolima. U 13. stoljeću Džingis-kan i njegovi nasljednici podijelili su ih na četiri skupine i raselili azijskim prostranstvima. Etnonim se u kineskim izvorima još pojavljuje i u oblicima Zházhǐlàdăi (札只刺歹), Yālàyìer (押刺亦而), Zhácìyìr (札刺亦儿) i Cházhálà (茶札刺) (Кычанов, 1997: 179; Пэрлээ, 1963: 315; Рашид ад-Дин, 1952, I, 1: 92-93, 1952, I, 2: 18; Ускенбай, 2010: 480-482).

${ }^{64}$ Rod Bordžigin (mong. Borǰigin; kin. Bèiérzhǐjīn 孛児只斤, Bóěrjìjítè 博爾濟吉特) bio je vladarski rod poznat i pod nazivom Zlatni rod (mong. Altan urug). Prema Rašīduddīnu, značenje riječi Bordžigin jest »plavooki«, jer su se pripadnici roda isticali plavim očima i riđom kosom. Mongolski povjesničar A. Očir to ime izvodi od riječi boru - »sivi, sivkast, sijed « i tegin - »titula, pridodana uz ime mlađih članova vladarske obitelji; princ« (Очир, 1996: 3-4; Рашид ад-Дин, 1952, I, 
vodili su starješine iz roda Činō, a onda je nastupila promjena u genealogijskoj liniji mongolskih rodova. Ti događaji u Tajnoj povijesti povezani su s predajom o Dobun-mergenu (kin. Duǒbēn mièérgàn 架奔笺児干) i Alan-qo’a (kin. Ālán huōā 阿闌中豁阿). Nakon smrti Dobun-mergena rod Činō i zajednica rodova/ plemena genetički povezanih s drevnim Turcima odvojili su se i osnovali savez od četiri plemena - Dörben ${ }^{65}$ (kin. Duǒérbiān 架児邊). Novu zajednicu mongolskih plemena osnovali su potomci Alan-qo'a, koji su u 11. stoljeću uspostavili rodbinske i političke veze s plemenima Mangut (kin. Mánghūtì 忙中忽惕), Bargudžin ili Barga (mong. Barquǰin; kin. Bāérhūzhēn 巴舌児中忽真, Bā’ěrhǔ 巴爾虎), Olhunut (mong. Olqunu'ut; kin. Wòlēihūnèwùtì 斡勒中忽訥惕) i Onggirat. Kod Rašīduddīna se nazivaju Mongoli-Niruni i dijele se na tri podskupine: 1) Nirun: potomci Alan-qo'a do Kabul-kana, braća Kabul-kana i njihovi potomci rodovi/ plemena: Hadargin, Herigen, Ba'arin, Barulas, Besüt, Buda'at, Cinas, Doqolat, Dörben, Je'ürit, Mangqut, Noyaqin, Qataqin, Qingqiyat, Salji'ut, Sanci'ut, Sügen, Suqai'ut, Tayici'ut i Uru’ut, 2) Kijat (Qiyat): od Kabul-kana do Jesugej-batara, braća Jesugeja i njihovi potomci i 3) Kijat-Bordžigin (Qiyat- Borǰigin): počinje Jesugej-batarom, Džingis-kanovim ocem. Završetak formiranja nirunske skupine i politička dominacija roda Bordžigin u Mongoliji povezani su s Kabul-kanom i

2: 48). Predaja zapisana u Tajnoj povijesti Mongola govori kako je Alan-qo'a nakon smrti supruga Dobun-mergena rodila tri sina, od kojih je najmlađi bio Bodončar-mungkag. Prema legendi, mlađi sinovi bili su božanskog podrijetla, koje im je trebalo osigurati pravo na prijestolje. Genealogijski slijed Džingis-kanovih predaka iz roda Bordžigin jest: Bodončar-mungkag $\rightarrow$ Kabiči-batar (mong. Qabiči-ba'atur; kin. Hébìchì bǎātūlún 中合必赤把阿秃舌侖) $\rightarrow$ Menen-tudun (kin. Miènián tǔdūn 策年土敦) $\rightarrow$ Kači-kulug (mong. Qači-külük; kin. Héchì qūlǔkè 中合赤曲魯克) $\rightarrow$ Kajdu (mong. Qaidu; kin. Hăidōu 中海都) $\rightarrow$ Baj-šinkor-dogšin (mong. Bai-šingqor-doqšsin; kin. Bó shēnghuōér duōhēishēn 伯升中豁児多黒申) $\rightarrow$ Tumbinaj-sečen (kin. Túnbìnăi-xuēchán 屯必乃薛禪) $\rightarrow$ Kabul-kan (mong. Qabul-qahan; kin. Hébùlei héhăn 合不勒合罕) $\rightarrow$ Bartan-batar (kin. Bǎértán bǎātūér 把児壇把阿秃児) $\rightarrow$ Jesugej-batar (mong. Yisügei-ba'atur; kin. Yěsùgāi bǎātūér 也速該 把阿秃児) $\rightarrow$ Temudžin (mong. Temüǰin; kin. Tiēmùzhēn 帖木真). B. R. Zoriktuev smatra da je rod Bordžigin stariji, a osnivač roda bio je Bordžigidaj-mergen (mong. Borjigidai-mergen; kin. Bèiérzhǐjídăi-mièérgàn 孛児只吉多策児干). Upravo je genealogija bila izvor vlasti predstavnika »zlatnog roda« Džingis-kana. Četvorica njegovih sinova od prve žene Börte - Džuči (mong. J̌oči; kin. Zhuōchì 拙赤, Shùchì 术赤), Čagataj (mong. Ča'adai; kin. Cháādăi 察阿歹, Chágětái 察合 台), Ugedaj (mong. Ögödei; kin. Wògēdăi 斡歌多, Wōkuòtái 窝阔台) i Tuluj (mong. Tolui; kin. Tuōléi 拖雷, Tuōléi 托雷) - i njihovi direktni nasljednici imali su isključivo pravo na prijestolje (Allsen, 1994: 330; de Rachewiltz, 2004, 1: 3-10; Юрченко, 2006: 153, 214, 287; Кляшторный i Султанов, 2009: 223-224; Козин, 1941: 80-84; Rybatzki, 2006: 141; Зориктуев, 2011: 67).

65 Duva-sokor (mong. Duwa-soqor; kin. Dōuwā suǒhuōér 都蛙鎖中豁児), stariji brat Dobun-mergena, imao je četiri sina. Nakon očeve smrti oni su odbili priznati vlast strica, osamostalili su se i osnovali posebni rod Dörben, koji je postao osnova budućega plemenskog saveza. U literaturi je prihvaćeno mišljenje kako je taj etnonim izveden od broja dörben - »četiri« i označuje savez četiri plemena. No on bi mogao označivati pleme koje je dobilo ime Dörben, prema broju sinova Duvasokora (Ангархаев, 2003: 61; de Rachewiltz, 2004a: 3; Козин, 1941: 80). Nakon pada dinastije Yuán u Kini u drugoj polovini 14. stoljeća, Mongoli su se podijelili na istočne i zapadne. Dörbeni su imali značajnu ulogu među zapadnim Mongolima - Ojratima. 
njegovim sinovima (Ангархаев, 2003: 54; Bira, 1998: 245; Коновалов, 1999: 130-131; Кычанов, 1966: 269; 1980: 141; 1997: 179; Пэрлээ, 1963: 314-315; Рашид ад-Дин, 1952, I, 1: 78, 79; Rybatzki, 2006: 136; Викторова, 1980: 162, 166; Зориктуев, 2011а: 66, 71-72).

U povijesnim izvorima, Tajnoj povijesti Mongola, a i kod Rašīduddīna, mongolska plemena dijele se na dvije skupine-»stepska plemena«i $i$ šumska plemena«. Od 11. do 13. stoljeća plemena nastanjena u zemljama oko Bajkala i u Mongoliji nisu bila jedinstvena cjelina, govorila su različitim plemenskim dijalektima i nalazila su se na različitim stupnjevima kulturnog razvoja. Transformacija šumskih mongolskih plemena u nomade-stočare odvijala se u prisutnosti turkijskih plemena, koja su u to doba činila značajni dio stanovništva mongolskih stepa. Lingvistička istraživanja pokazala su kako je sav mongolski leksik vezan uz nomadsko stočarstvo turkijskog porijekla. ${ }^{66}$ Do 13. stoljeća proces posuđivanja riječi u tim jezicima bio je jednostran - iz turkijskih jezika u mongolski (Щербак, 1986: 48). Također, od turkijskih plemena preuzeli su navike $\mathrm{i}$ iskustva nomada te mnoge obrasce stepske materijalne kulture, u tom smislu i rasklopive domove - okrugle jurte od filca (mong. ger). Mongolska »stepska plemena« (mong. ke’er-ün irgen; kin. kèélún yiérjiān 客額 舌侖亦児堅) u području Trorječja, zbog prirodnih uvjeta toga kraja, mogla su se osim nomadskim stočarstvom baviti i tradicionalnim zanimanjima, u kojima je važnu ulogu imao lov na šumsku divljač. ${ }^{67}$ Prema riječima B. Ja. Vladimircova, Mongoli-nomadi od 11. do 13. stoljeća su bili »nomadi-pastiri i lovci istovremeno, ali ipak je osnova njihova ekonomskog života bilo stočarstvo« (Allsen, 1994: 328;

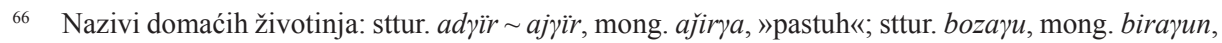
»tele«; sttur. öküz, mong. üker üküz, »bik«, »krupna rogata stoka«; sttur. Qatïr, mong. qatir, qačir, »mazga«; sttur. qoč, qočar, qočyar, mong. quča, qučan, »ovan«; sttur. qoj qon, qojun qojïn, mong. qoni, qonin, »ovca«; sttur. tebä tevä tevi, mong. temēn, temegen, »dvogrba deva«;

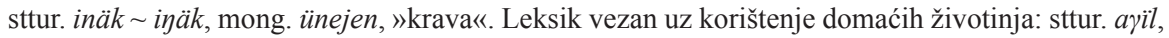

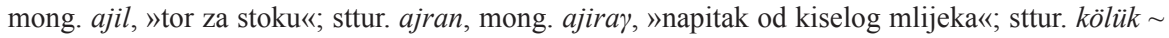
kölü̈ü, mong. kölgen, k’ölge, »kola«; sttur. köč, mong. köske, »čergarenje, nomadski život«; sttur.

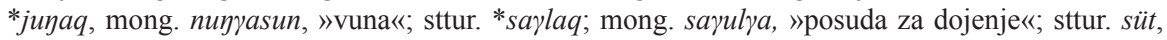

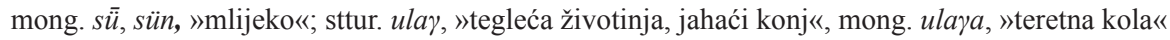
(Рассадин, 2009: 159-161; Щербак, 1966: 29; 1997: 94, 96, 109, 127, 128, 131, 137, 139, 150, 154, 161).

${ }_{67}$ Prema »Statutu lova« iz 1225., koji je bio uvršten u Veliku yasu, mongolski ratnici kada nisu bili na pohodu morali su usavršavati rukovanje oružjem odlaskom u lov. Vojska je trebala poznavati tehniku lova, koji je bio sredstvo učenja vojnih vještina i priprema za rat, jer se njime vježbalo kretanje ratnika i gađanje lukom. Početak zime bio je određen za sezonu velikog lova, u kojem je trebala sudjelovati svaka vojna postrojba. Lovci su bili postrojeni kao vojska - s centrom, desnim i lijevim bokom, svaki pod zapovjedništvom posebno određenog vođe. Cijelim pothvatom upravljao je veliki kan. Oko ogromnog teritorija određenog za lov, koji je obuhvaćao tisuće četvornih kilometara, formirao se krug hajkača. Tijekom jednog do tri mjeseca krug se postupno sužavao i tjerao divljač u središte, gdje je čekao veliki kan. Posebni poslanici izvještavali su kana o tijeku pothvata, vrsti i broju divljači. Detaljnije o važnosti lova kod srednjovjekovnih Mongola vidi u Кушкумбаев, 2009: 81-89. 
Асеев, 2009: 196-197; Билэгт, 2007: 192; Дробышев, 2011: 11, 13-14, 18-19; Golden, 2009: 18-19; Кызласов, 1975: 171; 1992: 150, 152; Щербак, 1997: 55, 93; Викторова, 1980: 171; Владимирцов, 1934: 33-36, 41, 58-59).

Osvrnut ćemo se na još jednu temu iz mongolske povijesti, kojoj je u literaturi posvećeno dosta prostora - naseljavanje sjevernih mongolskih plemena, »šumskih plemena« (mong. hoy-yin irgen; kin. huáiyīn yiérjiān 槐因亦児堅), oko Bajkalskog jezera. Osnovna gospodarska djelatnost tih plemena bila je lov i ribolov. U drugoj polovini 1. tisućljeća područje oko Bajkalskog jezera naseljavala su turkijska plemena Kurikan (sttur. Qurïqan JNr丩> ; kin. Gǔlìgàn 骨利幹), Bajirku (sttur. Bayïrqu ل4DS; kin. Báyěgǔ 拢野古, Báyěgù 拢野固, Báyègù 拢曳固), Pu-ku/

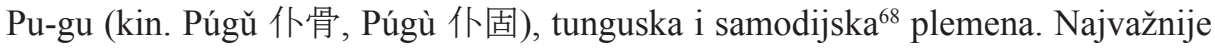
mjesto pripadalo je Kurikanima, ${ }^{69}$ koji se arheološki identificiraju s kurumčinskom kulturom $^{70}$ (rus. курумчинская культура). Ta se kultura prostirala na teritoriju s obje strane Bajkala, ali je njezin osnovni areal bio u Pribajkalju - gornji tok Lene, gornji i srednji tok Angare i područje između rijeka. U zapadnom Zabajkalju najvažniji etnos bili su Bajirku, koji se arheološki mogu povezati s bargutskom kulturom $^{71}$ (rus. баргутская культура). Dolaskom mongolskih plemena počelo je razdoblje asimilacije turkijskih plemena, koje je rezultiralo stvaranjem novog etnosa - Protoburijata, čija su osnova bila mongolojezična plemena. Pojedinosti iz povijesti tih plemena nisu poznate zbog nedostatka izvora, ali se pretpostavlja kako je mongolska etnička jezgra od 11. do 13. stoljeća preuzela vodeći položaj među stanovništvom Pribajkalja (Цыбиктаров, 2001: 170, 177, 184; Гоголев, 1993: 199, 202; Худяков, 1989: 29; Коновалов, 1989: 5-6; Нимаев, 1988: 67, 68, 70, 72, 79, 80, 81, 89; 1993: 145, 149; Окладников, 1958: 200; Зориктуев, 1989: 105, 107, 109; 1993: 121, 122-123, 125, 129; 2011a: 60-61). Sjevernom granicom rasprostranjenosti srednjovjekovnih mongolskih plemena bilo je područje Pribajkalja i Zabajkalja. O tome kada su Mongoli počeli naseljavati te prostore postoje u literaturi različita mišljenja. Tako se početak širenja mongolskih plemena u Zabajkalju datira u 7. - 11. stoljeće (Цыбиктаров, 2001: 193; Данилов, 1985: 90; Гоголев, 1993: 200; Ковычев, 1981: 79; Нимаев, 1993: 148; Зориктуев,

68 Samodijci, etnička i jezična zajednica sibirskih plemena koja su u 1. tisućljeću do početka 2. tisućljeća zbog migracija turkijskih naroda bila potisnuta iz Sajanskoga gorja na sjever. Plemena koja su ostala bila su asimilirana i ušla su u sastav turkojezičnih naroda južnoga Sibira. Burijatska lingvistica R. G. Žamsaranova smatra da je samodijskog porijekla bilo pleme Hori-Tumat, koje Tajna povijest Mongola ubraja među »šumske narode« (Жамсаранова, 2010: 122, 124, 127).

69 U staroturskim izvorima navode se i kao Üč Qurïqan ( kana«, što implicira postojanje kurikanskoga plemenskog saveza.

70 Kronološki se ta arheološka kultura najčešće datira u 6. - 10. stoljeće.

71 U dodiru s mongolskim plemenima Bajirku su prihvatili novo ime Bargudžin i postupno ušli u njihov sastav. 
1989: 108, 109; 1993: 124, 129; 2011a: 49, 63), a dolazak u Pribajkalje u 11. 13. stoljeće (Асеев, 2009: 193, 196; Цыбиктаров, 2001: 184; Нимаев, 1988: 74; Окладников, 1958: 206). Kolonizacija mongolskih plemena odvijala se u dvije faze. Najprije su stigla sjeverna, »šumska plemena«, a u drugom valu, početkom 2. tisućljeća, stepska plemena, koja su donijela nomadsku² tradiciju. Područje koje su naseljavala ta plemena pisani izvori 13. i 14. stoljeća nazivaju Bargudžin Tokum (mong. Baryujuin Tögüm; kin. Bāérhūzhēn Tuōkūmù 巴児中忽真脫窟木). Ono se prostiralo na obje strane Bajkala i obuhvaćalo je u Pribajkalju Angaro-lenski kraj te u Zabajkalju Barguzinsku nizinu i donji tok Selenge. Razmještaj plemena bio je približno sljedeći: u Zabajkalju, Barguzinskoj dolini, živjeli su Barguti, a južnije i istočnije Qori i Tulasi. Qori i Tumati locirani su i u angaro-lenskom kraju. Pribajkalje su naselila protoburijatska plemena Bulagačini i Keremučini. Osim njih u Bargudžin-Tokumu živjelo je tunguzojezično (preci suvremenih Evenkov) i turkojezično (potomci Kurikana) stanovništvo. Mongoli su sa zabajkalskim plemenima održavali bračne veze. Tako je Bartan-batar, Džingis-kanov djed, bio vjenčan sa Sunigel-fudžin iz plemena Bargut. Početkom 13. stoljeća, između 1201. i 1206., u Bargudžin-Tokum stigli su Džingis-kanovi poslanici braća Turu-kadžarbagatur i Sartak-bagatur. Oni su sklopili savez s Kadan-Ajinom, vođom Barguta, čiju su vlast priznavala plemena zabajkalskog dijela Bargudžin-Tokuma. Prema zapisu u Tajnoj povijesti Mongola, ostale »šumske narode« oko rijeke Šisgis pokorio je 1207. Džuči, najstariji Džingis-kanov $\sin ^{73}$ (Цыбиктаров, 2001: 203; Чимитдоржиев, 1995: 96; Нимаев, 1993: 158; Зориктуев, 1995: 90, 91; 2000: 119; 2011a: 132).

Prisutnost Mongola u Pribajkalju i Zabajkalju utvrđena je arheološkim nalazima, od kojih su najvažniji grobovi, u kojima se pojavljuje nekoliko varijanti ukopa: samo u zemlju, u brezovoj kori, lijesu od dasaka i lijesu od balvana. Sve varijante pogrebnog obreda sadržavaju potkoljenične i bedrene kosti ovna, koje se u ovom slučaju smatraju »etničkim indikatorom«. Arheološka kultura koja se povezuje s Mongolima do 14. stoljeća, u ruskoj historiografiji naziva se ranomongolska

72 Drugačije mišljenje iznio je burijatski arheolog D. D. Dašibalov, koji smatra kako su nomadsku komponentu kod stanovništva sajantujske kulture najvjerojatnije proširili turkijski Kipčaci (Дашибалов, 2005: 130, 161, 169).

73 Vlast Mongola priznala su ova plemena: Ojrat (kin. Wòyìlàtì 斡亦刺惕), Burijat (kin. Bùlǐyátì 不舌 里牙惕), Bargun (kin. Bāérhún 巴児中渾), Ursut (kin. Wùérsùtì 元舌児速惕), Kabkanas (mong. Qabqanas; kin. Hébǔhénsīà 中合卜中合納思), Kangas (mong. Kangqas; kin. Kānghésī 中康中 合思), Tubas (kin. Tūbāxī 秃巴昔). Kada je stigao do teritorija Tumen-Kirgiza (mong. TümenKirgisut; kin. Tūmián-Qúérjísùti 秃綿乞舌児吉速惕), njihovi vođe izjavili su pokornost Džučiju. Nakon toga su mongolsku vlast priznala šumska plemena iz Sibira - Kesdim (kin. Kèsīdeyīn 客思 的音), Bajit (kin. Bāyìtì 巴亦惕), Tukas (kin. Tūhésī 秃中合思), Tenlek (kin. Tiánlièkè 田列克), Tö'eles (kin. Tuōélièsī 脫額列思), Tas (kin. Tăsī 塔思) i Badžigit (mong. Baǰigit; kin. Bāzhřjídá 巴只吉荅) (de Rachewiltz, 2004, 1: 163-164; Козин, 1941: 174-175). 
kultura $^{74}$ (rus. раннемонгольская культура). Materijalni ostaci te kulture pronađeni su na južnim stepskim i šumsko-stepskim područjima Zabajkalja te u stepama Mongolije i Pribajkalju (Асеев, 2009: 196; Цыбиктаров, 2001: 177, 178, 182; Данилов, 1985: 87, 89; Именохоев, 1989: 57; 1992: 26, 29, 35, 46; Коновалов, 1989: 8; Ковычев, 1981: 73, 78; Окладников, 1958: 204).

\section{MONGOLI I CARSTVO LIÁO}

U drugoj polovini 9. stoljeća zbog slabe središnje vlasti, unutrašnjih sukoba i prirodnih katastrofa došlo je do značajnog slabljenja dinastije Táng. Nakon velike pobune Huáng Cháo (Huáng Cháozhīluàn 黃巢之亂 875. - 884.) središnja se vlast raspala, a Carstvom su zavladali provincijski vojni zapovjednici. Posljednji car dinastije, Āidì (哀帝), zbačen je s vlasti 907. Kina je tada ušla u razdoblje Pet dinastija (907. - 960.) i Deset kraljevstva (902. - 979.) (Wǔdài Shíguó 五代十國), u kojemu su zemljom vladale slabe, često međusobno sukobljene dinastije (Думан, 1986: 14; Gernet, 1990: 267-268; Somers, 1979: 714-789).

Pad dinastije Táng i nepostojanje središnje vlasti na stepi nakon pada Ujgurskoga Kaganata, samo su ubrzali širenje vlasti Qìdāna. Qidanski vođa Ābăojī bio je 907. izabran za starješinu svih osam qidanskih plemena, a 916. proglasio se carem. Carstvo Qìdāna (Qìdān guó 契丹國), poznatije pod imenom Liáo (遼 916. - 1125.), vodilo je uspješne pohode i njihovu su vlast priznala plemena Xī, Dádá, Yújuélǐ, Shìwéi, Nǚzhēn, Dăngxiàng (党項) ${ }^{75}$, Tǔhún (吐渾) ${ }^{76}$ i Shātuó (沙陁) $)^{77}$ (Е Лун-ли,

74 Na području zapadnog Zabajkalja (Burjatija) arheolozi su izdvojili dva razdoblja te kulture: hojcegorski (7. - 10. stoljeće) i sajantujski (10./11. - 14. stoljeće). Nalazi hojcegorskog razdoblja, s prevladavajućim elementima turkijske kulture, pripisuju se mongolojezičnom stanovništvu Burjatije, koje se nalazilo pod vlašću Ujgurskoga Kaganata. Sajantujski nalazi povezuju se s mongolskim plemenima koja su se u tom kraju pojavila krajem 10., početkom 11. stoljeća (Цыбиктаров, 2001: 178; Именохоев, 1989: 62; Коновалов, 1989: 10, 13).

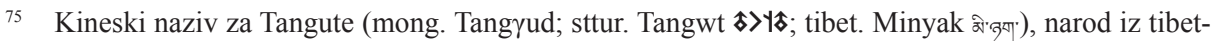
sko-burmanske jezične skupine. Osnovali su carstvo Xī Xià (西夏 1038. - 1227.) koje se nalazilo u sjeverozapadnoj Kini, današnjim pokrajinama Níngxià, Gānsù, istočni Qīnghăi, sjeverni Shănxī i sjeveroistočni Xīnjiāng. Na svom posljednjem pohodu Džingis-kan je osvojio tangutsku državu.

76 Tǔhún ili Tǔyùhún (吐谷渾), ogranak mongolojezičnih Xiānbēia. U 9. i 10. stoljeću nastanjivali su dijelove današnjih kineskih pokrajina Shănxī i Unutarnja Mongolija. Kada je car Gāozǔ (高祖 936. - 942.) iz dinastije Kasniji Jin (Hòu Jìn 後互 936. - 946.) ustupio Qìdānima dio teritorija, Tǔhúni su postali ovisni o dinastiji Liáo (Таскин, 1984: 264-265).

77 Turkijsko pleme iz Zapadnoga Kaganata koje je obitavalo u Džungariji. U kineskim izvorima smatraju se potomcima xiongnuskog plemena Chǔyuè (處月), koje se počelo nazivati Shātuó po istoimenoj pustinji. Nakon pada Zapadnoturskoga Kaganata priznavali su vlast dinastije Táng. Potkraj 8. stoljeća dio Shātuó priznao je vlast tibetanskoga kraljevstva Tǔbō (吐蕃). U prvoj polovini 10. stoljeća, razdoblju Pet dinastija i Deset kraljevstva, imali su značajnu ulogu u sjevernoj Kini, gdje su osnovali tri dinastije - Kasniji Tang (Hòu Táng 后唐 923. - 936.), Kasniji Jin (Hòu Jìn 後晉 936. - 946.), Kasniji Han (Hòu Hàn 後漢 947. - 950.) i kraljevstvo Sjeverni Han (Běi Hàn 北漢 951. - 979.) (Grousset, 1970: 126-127; Гумилев, 2005: 292; Wittfogel i Fêng, 1949: 107). 
1979: 313). Qidanski prodor u srednjoazijske stepe, koji je počeo pohodom 924. i trajao do početka 11. stoljeća, pomaknuo je granice carstva daleko na zapad u dolinu rijeka Orhon i Tuul te na sjever u dolinu rijeka Kerulen i Selenga. Danak carstvu plaćala su plemena na Altajskom gorju, Kirgizi i ostala plemena u južnom Sibiru. Daljnji qidanski prodor u srednju Aziju zaustavila je dinastija Karahanida (per. Karāhānījān نَايناخارقَ kin. Kālāhánguó 喀喇汗国) (Худяков, 1993: 167, 168; Крадин, 2011: 8; Пиков, 2001; Потапов, 1953: 99; Sinor, 1998: 231; Sinor, Shimin i Kychanov, 1998: 200; Twitchett i Tietze, 1994: 65-66; Викторова, 1980: 143; Wittfogel i Fêng, 1949: 62). Ekspanzija Qìdāna pokrenula je migracijske i etničke procese, koji su imali dalekosežne posljedice za povijest mongolskih i turkijskih plemena. Potonja su počela napuštati mongolske stepe ${ }^{78}$ i migrirati na zapad, a njihovo su mjesto postupno zauzimala mongolska plemena. U 10. i 11. stoljeću u sjevernoj Mongoliji pojavljuju se nove etnopolitičke zajednice - kaganati Kereita (kin. Kèliè 克烈), Tatara, Merkita (kin. Mièrqũ 茂兒乞) i Najmana (kin. Năimán 乃蛮) (Biran, 2005: 33; Дашибалов, 2005: 57; Екеев, 2010: 34-35; Grousset, 1970: 128; Худяков, 1993: 166; Кычанов, 1980: 143; Кызласов, 1975: 170; 1992: 135, 137, 148, 156; Кляшторний і Савинов, 2005: 141; Кляшторный і Султанов, 2009: 158; Mote, 1999: 57; Spuler, 1966: 188).

Za vladavine Déguānga (德光 927. - 947.) carstvo Liáo bilo je podijeljeno na dva dijela - Sjeverna oblast (Běi miàn 北面) i Južna oblast (Nán miàn 南面). Administracija Sjeverne oblasti upravljala je Qìdānima, pokorenim nomadskim i sjedilačkim narodima. S ciljem držanja u pokornosti mjesnih plemena, za kontrolu nad zemljama sjeverno od pustinje Gobi (Shāmòfú 沙漠府) osnovani su »zapadna administracija glavnoga vojskovođe za gušenje pobuna; straža iz plemena Àowěi (奧隗); administracija vojnog zapovjednika na rijeci Kerulen (kin. Lújū 驢駒); administracija upravitelja Dăotàlı̌nga (倒撻嶺); razne vojne postrojbe za smirivanje plemena Dádá (韃靼), Ménggǔ i Díliè (迪烈) $)^{79}$ « (Е Лун-ли, 1979: 301). U prvoj polovini 10. stoljeća od napada nomadskih plemena sa zapada i sjevera Qìdāni su se branili aktivnim vojnim pohodima na stepi. No za vladavine Shèngzōnga (圣宗

78 U historiografiji postoji mišljenje kako su Qìdāni pohodom 924. protjerali Kirgize iz Mongolije, iako izvori to ne potvrđuju. Izvori govore o plemenima Qāy (kin. Bái Xí 白䨳) i Qūn (kin. Hún 渾) koja su početkom 11. stoljeća iz mongolske stepe migrirala u zapadni Sibir, sjevernu Džungariju i sjeveroistočno Sedmorječje. Etnička pripadnost tih plemena nije dokraja razjašnjena. Prema Ju. S. Hudjakovu, u doba carstva Liáo turkijska plemena i dalje su obitavala na velikom području središnje i zapadne Mongolije. Ujguri se u Mongoliji spominju sve do 14. stoljeća, kada su počeli migrirati u istočno Zabajkalje (Golden, 1990: 363; Гуркин, 2004: 40-45; Худяков, 1993: 171; Кляшторний і Савинов, 2005: 140-141; Кумеков, 1972: 122-125; Кызласов, 1992: 136).

79 Turkijsko pleme koje je u 10. i 11. stoljeću nastanjivalo istočnu Mongoliju. Od 930. priznavali su vlast dinastije Liáo. Car Shèngzōng podijelio ih je na Běi Díliè (北廸烈) i Diélǔ Díliè (迭魯敵烈). Godine 1096. zajedno s Wūgǔ bili su preseljeni u područje rijeke Wūnà (烏納). Nakon pada dinastije Liáo dio je migrirao u srednju Aziju, a ostatak su Džurčeni raselili po kineskim pokrajinama. 
982. - 1031.) bila je prihvaćena kineska pasivna strategija obrane, koja se sastojala u utvrđivanju granica. Za obranu od nomadskih plemena izgrađen je tzv. Džingiskanov zid, dug oko sedamst kilometara, na teritoriju sjeveroistočne Mongolije, Kine i Zabajkalja. ${ }^{80}$ Osim toga za očuvanje vlasti u mongolskim stepama izgrađeno je u pograničnom području više od dvadeset utvrđenih gradova. ${ }^{81}$ Administracija gradova i konjanički odredi osiguravali su kontrolu teritorija u mongolskim stepama i ubiranje danka od mjesnog stanovništva. Važan zadatak qidanskih garnizona u utvrdama na stepi bilo je brzo suzbijanje prodora sjevernih nomada. Nakon uspješnog pohoda 994. protiv plemena na zapadnoj granici, Qìdāni su počeli u porječju Kerulena i Tuula graditi pogranične utvrde. Na mjestu ujgurskoga grada Kědūna (可敦) bio je osnovan qidanski grad Zhènzhōu (鎮州). Godine 1004. u njega je smješten garnizon, koji se sastojao od pripadnika sjeverozapadnih plemena i Qìdāna, a navodno je brojio dvadeset tisuća konjanika. Za njihovu opskrbu brinulo se sedamsto obitelji deportiranih Bohajaca, Džurčena i Kineza, koji su osim u Zhènzhōu bili naseljeni i u obližnjim utvrdama Fángzhōu (防州) i Wéizhōu (維 州). Važnu ulogu u formiranju vojnih garnizona qidanskih pograničnih utvrda imala su okolna mongolska plemena. Kako se čini, mjesna nomadska plemena često su napadala pogranične utvrde. Pleme Dádá opsjelo je 1013. grad Zhènzhōu, koji je bio u okruženju više mjeseci. Godine 1012. i 1014. plemena na gornjem toku Kerulena ustala su protiv qidanske vlasti. Pobunu je ugušio Qidanski ministar Yelü Shìliáng (耶律世良) istrijebivši značajan dio plemena. Preživjele nomade naselio je u dvije utvrde, građene od 1012. do 1015. na gornjem Kerulenu (Цэвээндорж et al. , 2008: 197, 199-200; Дробышев, 2010: 113-114; Худяков, 1993: 168, 171; Крадин, 2011: 12, 163-164; Крадин і Ивлиев, 2010: 148, 152; Крадин, Ивлиев і Васютин, 2013: 53-54; Ларичев, 2007: 96; Пэрлээ, 1962: 55-62; Sinor, 1998: 232; Васютин, 2011: 112, 114; Wittfogel i Fêng, 1949: 67, 435, 587).

O mongolskim plemenima u razdoblju carstva Liáo u izvorima ima malo podataka. U Zapisima o cartvu Liáo (Qìdān guó zhì 契丹國志) ${ }^{82}$ izvještava se: »Ravno na sjever zemlje Qìdāna dopiru do područja Měnggǔlǐ. U tom području nema vladara, koji bi upravljao narodom. Stanovništvo se ne bavi zemljoradnjom, [osnovno] zanimanje je lov. Ljudi ne žive trajno na jednome mjestu, već se u sva četiri godišnja doba sele u potrazi za dobrom travom i vodom. Hrane se samo mesom i kumisom. S Qìdānima ne ratuju, već s njima trguju proizvodima od kože i dlake

80 Obrambeni sustav sastojao se od zida i više desetaka utvrda. Izgrađen je za vladavine careva Shèngzōnga i Xīngzōnga (兴宗 1031. - 1055.). Služio je za obranu sjeverozapadne granice od plemena Wūgǔ, Yújué, Běi Zǔbǔ i Shìwéi (Алкин, 2001: 60-62).

81 Glavnina utvrda izgrađena je u srednjoj Mongoliji uz rijeku Tuul.

82 Autor je te kronike, napisane 1180., Yè Lónglǐ (葉隆禮), visoki činovnik iz carstva Južni Song (Nán Sòng 南宋 1127. - 1279.). 
krupne rogate stoke, ovaca, deva i konja. Na jugu od toga područja, na udaljenosti većoj od četiri tisuće $l i$, nalazi se Vrhovna prijestolnica.« Iz toga opisa proizlazi kako Mongoli nisu predstavljali opasnost za carstvo Liáo, jer su najvjerojatnije bili njihovi podanici. Isti izvor navodi plemena Biēgǔlǐ (撆古里) i Dádǎ (達打), koja su živjela sjeverozapadnije od Mongola, kao trajnu opasnost za carstvo. Od njih su Qìdāni »često trpjeli poraze«. Iako su za obranu imali sto tisuća ljudi i poduzimali kaznene pohode, neprijatelja ipak nisu uspijevali zaustaviti (Дробышев, 2010: 119; Е Лун-ли, 1979: 305-306). Dinastijska kronika Povijest dinastije Liáo (Liáo shǐ 遼史 $)^{83}$ navodi kako je mongolsko poslanstvo 1084. stiglo na qidanski dvor. U historiografiji postoji mišljenje da je tada mongolski starješina bio Tumbinaj-sečen. Prema L. L. Viktorovoj, mongolski starješine od tada su uspostavili trajne odnose s dinastijom Liáo i sklapali brakove s djevojkama iz uglednih qidanskih plemićkih rodova (Hambis, 1970: 130; Пэрлээ, 1963: 315; Викторова, 1980: 166-167; Wittfogel i Fêng, 1949: 592).

U prvoj polovini 10. stoljeća u povijesnim izvorima pojavljuje se etnonim Zǔbŭ (阻卜), ${ }^{84}$ naziv za nomadska plemena koja su živjela u sjevernoj Mongoliji. Pojava toga plemenskog saveza povezana je s migracijskim i etničkim procesima koje su pokrenuli pohodi Qìdāna. U historiografiji prevladava mišljenje da je Zǔbǔ uopćeni naziv za etnički i lingvistički različita plemena. Prema nekim autorima, etničku osnovu tog saveza činila su upravo mongolska plemena, ${ }^{85}$ od kojih su najvažnije mjesto zauzimali Tatari. U savez je možda ulazila i onon-kerulenska skupina mongolskih plemena (Хойт, 2008: 19; Воробьев, 1975: 331). Kinezi su prema mjestu prebivanja razlikovali tri skupine Zǔbǔ - zapadni Zǔbǔ (Xī Zǔbǔ 西阻卜), sjeverni Zǔbǔ (Běi Zǔbǔ 北阻卜) i sjeverozapadni Zǔbǔ (Xīběi Zǔbǔ 西北阻卜). Ruski povjesničar G. G. Pikov piše da je »teritorij koji su naseljavali Zǔbǔ bio značajan. Na jugu je granica s Liáo prolazila kroz sjeveroistočni dio pustinje Gobi, a na sjeveru se područje Zǔbǔ prostiralo sjevernije od rijeke Kerulen « (Biran, 2005: 27; Дробышев, 2010: 116-117; Mote, 1999: 57; Пиков, 2001; Twitchett i Tietze, 1994: 138; Wittfogel i Fêng, 1949: 101-102). Nakon velikoga zapadnog pohoda Ābăojīa 924., Zǔbǔ su bili pokoreni, ali njihove zemlje nisu pripojene carstvu

83 Sastavljena sredinom 14. stoljeća pod uredništvom dvorskog povjesničara Toqto'a (kin. Tuōtuō 脱脱), u vrijeme vladavine mongolske dinastije Yuán (元 1271. - 1368.; mong. Dai Ön Yeke Mongyol Ulus).

84 Ostali oblici etnonima - Zǔpǔ (阻革業), Zhúbùgū (术不姑), Shūbăo (殊保). U historiografiji postoje tri objašnjenja etimologije toga etnonima: Zǔbǔ je qidanski naziv za Tatare; tibetanski naziv sog po, inače nejasan Qìdānima, prepisan kineskim hijeroglifima; izveden je iz srednjemongolske riječi sibayu(n) (Хойт, 2008: 15).

85 Prema S. K. Hojtu, mongolska komponenta saveza sastojala se od shiweiskih plemena koja su prva izašla na stepu (Хойт, 2008: 13). 
Liáo. Spadali su u skupinu podanika koja je plaćala veliki danak ${ }^{86}$ Zbog pomoći u borbi s pobunjenim plemenima, ali i istaknutog položaja u nomadskoj hijerarhiji, zubuskom starješini Wūbā (烏八) dvor je 1014. dodijelio visoku titulu wáng (王). Pokušaji Qìdāna da povećaju danak i pripoje njihov teritorij nailazili su na snažan otpor. ${ }^{87}$ Kako bi umanjili snagu nomada, Qìdāni su nekoliko puta zabranili prodaju željeza i bakra, kako ovi ne bi usavršili svoja oruđa i oružja, ali i onemogućili kovanje krivotvorenog novca. Vrhunac moći Zǔbŭ su postigli 1089., kada je njihov energični starješina Mógǔsī (磨古斯) 88 postao vođom saveza plemena. Godine 1092. na pohodu protiv jednog iz sjevernih plemena Qìdāni su usputno napali sjeverne Zǔbǔ i tako izazvali dugotrajni rat. Sljedeće godine Mógǔsī je provalio na teritorij Liáo i nakon prve pobjede priključio mu se niz pokorenih plemena. Laka konjica Zǔbǔ u nizu pohoda iz liaoskoga zapadnog pograničnog područja odvodila je stada konja i ostale stoke. Velikim naporima i uz pomoć drugih plemena qidanski vojskovođa Yelü Wòtèlà (耶律斡特刺) nanio je 1095. Mógǔsīu težak poraz. Uskoro su novi vođe pobunjenih plemena izjavili pokornost caru Dàozōngu (道宗 1055. 1101.). Mógǔsī je nastavio borbu do 1100 ., kada je zarobljen i pogubljen, a mir na stepi uspostavljen je dvije godine poslije. Pred kraj carstva Liáo, kada su Qìdāni bili zaokupljeni borbom protiv Džurčena, Bǔqiúzhǐ (補球只), vođa Zǔbǔ, 1119. podigao je ustanak i oslobodio se qidanske vlasti. Nakon uspostave džurčenske dinastije Jīn (金 1115. - 1234.) Zǔbǔ su više puta napadali carstvo, ali su nakraju morali prihvatiti njegovu vlast (Дробышев, 2010: 111, 116-117; Гумилев, 2004: 107; Ларичев, 2007: 54; Mote, 1999: 57; Пиков, 2001; Twitchett i Tietze, 1994: 138-139).

Na kraju 11. stoljeća u Mandžuriji je počeo uspon plemenâ Džurčena. U razdoblju carstva Liáo dijelili su se na »kulturne Džurčene« (Shú Nǔzhēn 熟女真), koji su obitavali južno od rijeke Hùntóng (混同), i »divlje Džurčene« (Shēng Nüzhēn 生 女真), koji su obitavali sjeverno od rijeke. Godine 1114. Āgǔdă (阿骨打 1068. 1123.), starješina plemena Wányán (完顏) iz redova »divljih Džurčena«, podigao je ustanak protiv qidanskog carstva. Nakon početnih uspjeha Āgǔdă je 1115. proglasio novu dinastiju Jīn. Iste je godine carstvo Sjeverni Sòng (Běi Sòng 北宋) sklopilo

86 Sačuvani su podaci o visini danka. Prema carskoj naredbi iz 1019., Zǔbǔ su godišnje morali dostaviti 1700 konja, 440 deva, 10.000 koža hermelina i 25.000 koža svizaca. Godine 1048. dostavili su 20.000 konja, dok su druga plemena davala od 300 do 10.000 konja (Дробышев, 2010: 121; Wittfogel i Fêng, 1949: 331-332, 357, 359).

87 Sukobi su vođeni 942., 983. - 984., 997. - 1000., 1007., 1012., 1020., 1026. - 1027. i 1069. - 1086. (Дробышев, 2010: 117; Хойт, 2008: 23-25; Пиков, 2001; Wittfogel i Fêng, 1949: 583, 585-588, 591, 593).

88 Sjeverna skupina Zǔbǔ, kojoj je pripadao Mógǔsī, u literaturi se poistovjećuje s Kereitima. Oni su 1007. prihvatili nestorijansko kršćanstvo, a njihov tadašnji vođa uzeo je kršćansko ime Marcus. Neki autori smatraju da je ime Mógǔsī kineska transkripcija od Marcus (Dunlop, 1943: 277; Grousset, 1970: 191; Гумилев, 2004: 99, 104; Хойт, 2008: 24). 
savez s Džurčenima kako bi vratilo Šesnaest oblasti ${ }^{89}$ koje su u prvoj polovini 10. stoljeća potpale pod vlast Qìdāna. Nakon propalih mirovnih pregovora koje je inicirao qidanski car Tiānzuòdì (天祚帝 1101. - 1125.) neprijateljstva su obnovljena 1119., pa su slijedile zajedničke akcije dinastija Jīn i Sòng. U tim događajima Mongoli su bili važni saveznici Qìdāna. Mongolski povjesničar H. Perlee navodi kako su 1122. Mongoli poslali značajnu pomoć Qìdānima, od navodno čak pedeset tisuća konjanika. Pritisnut džurčenskim vojskama, Tiānzuòdì je potražio utočište kod Tanguta, svojih posljednjih saveznika. Kada su 1124. Tanguti bili prinuđeni priznati vrhovništvo dinastije Jīn, Tiānzuòdì je izgubio posljednje utočište i nakon poraza 1125. pao je u džurčensko zarobljeništvo. Carstvo Liáo prestalo je postojati, a osnovna masa Qìdāna ostala je u južnoj Mandžuriji. ${ }^{90}$ Značajni dio Qìdāna ušao je u sastav Mongola. Oni su imali veliku ulogu u etnogenezi južnih Mongola i poslije mongolojezičnih naroda Unutarnje Mongolije (Е Лун-ли, 1979: 169, 175224; Franke, 1990: 409, 415; 1994: 218-226; Gernet, 1990: 356; Grousset, 1970: 134, 136; Ларичев, 2007: 118-131; Михайлов, 1993: 181; Mote, 1999: 194-196, 201-203, 208-209, 211-213; Пэрлээ, 1963: 316; Пиков, 1989: 53-63; Twitchett i Tietze, 1994: 140-151; Викторова, 1980: 169; Воробьев, 1975: 33-35, 49-51, 109-111, 314-316, 341-342; Wittfogel i Fêng, 1949: 101, 595-598).

U dramatičnim događajima pada dinastije Liáo, Yēlü Dàshí (耶律大石 1087. - 1143.), pripadnik qidanskoga carskog roda, uspio je 1124. nakon bijega iz džurčenskog zarobljeništva s odredom vojnika stići do grada Zhènzhōu na

89 Područje na teritoriju suvremenih provincija Héběi i Shānxī koje je odvajalo sjeverne stepe od autohtonih kineskih zemalja. Nakon pada dinastije Táng to je područje potpalo pod vlast dinastije Kasniji Tang. Godine 936. pobunjeni Shí Jìngtáng (石敬瑭) osnovao je uz pomoć Qìdāna dinastiju Kasniji Jin. U zamjenu za dobivenu pomoć morao je dinastiji Liáo ustupiti dio teritorija - Šesnaest oblasti. Vlast nad tim područjem omogućila je Qìdānima upletanje u poslove sjevernokineskih država. Nakon ponovnog ujedinjenja Kine dinastija Sòng neuspješno je pokušavala vratiti to područje (Е Лун-ли, 1979: 60-61, 63; Grousset, 1970: 129-130; Mote, 1999: 64-65; Twitchett i Tietze, 1994: 70; Викторова, 1980: 143; Wittfogel i Fêng, 1949: 60, 578).

90 Godine 1211., kada je počelo mongolsko osvajanje sjeveroistočne Kine, pod vodstvom Yelü Liúgē (耶律留哥), Qìdāni su zbacili vlast Džurčena i postali saveznici Mongola. Iduće godine Liúgē je bio proglašen vladarom obnovljenog carstva Liáo, koje je obuhvaćalo sjeverni dio poluotoka Liáodōnga (遼東). Za pomoć novom savezniku Džingis-kan je poslao vojskovođu Kětègēna (可 特哥). Kako su Qìdāni 1216. počeli provaljivati u Koreju, korejski dvor bio je prinuđen zatražiti pomoć od Mongola. Ujedinjene snage Mongola, džurčenske države Dōng Xià (东夏 1215. 1233.) i Koreje početkom 1219. nanijele su Liúgēu odlučujući poraz, a carstvo Liáo potpalo je pod mongolsku vlast. U vrijeme mongolske dinastije Yuán dio Qìdāna kojima je upravljao rod Dàhè (大贺) migrirao je iz porječja Liáohé (遼河) na gornji tok Amura, gdje su stupili u bliske odnose s lokalnim tunguskim plemenima - Džurčenima i Evenkima (kin. Ėwēnkè 鄂温克). U 15. i 16. stoljeću počelo je asimiliranje tunguskih rodova i formiranje nove etničke zajednice mongolojezičnih Dagura (mong. Daguur; kin. Dáwò'ěr 達㲦爾). Po analogiji s imenima tunguskih rodova, ime vladajućega qidanskog roda Dàhè promijenilo se u etnonim Dagur (Цыбенов, 2009: 12; Храпачевский, 2004: 291, 296; Janhunen, 1996: 162; Мелихов, 1977: 63-70; Михайлов, 1993: 181). 
sjeverozapadnoj granici. Oko njega su se počeli okupljati ostaci qidanske vojske i okolna plemena. U daljnjem slijedu događaja Dàshí se proglasio carem, a uzeo je i titulu gurkana (mong. gürqan; kin. gérhăn 葛兒罕, gǔérhăn 古児罕; per. Kūr khān (ن) (ن)روك ${ }^{91}$ Sazvao je kurultaj, na kojem su prisustvovali predstavnici »sedam oblasti i osamnaest plemena . ${ }^{92}$ Tako je osnovano kratkotrajno carstvo Sjeverni Liao (Běi Liáo 北遼 1124. - 1130.), pod čijim je utjecajem bila praktično cijela Mongolija. Za borbu protiv Džurčena i obnovu carstva Liáo Dàshí je pokušao sklopiti savez s carstvima Xī Xià i Južni Song. Uspješnija je bila suradnja s Tatarima, koji su neko vrijeme odbijali dostavljati konje carstvu Jīn. Kada je džurčenski general Yúdǔ (余 覩) ujesen 1129. osvojio Zhènzhōu, sljedeće godine Dàshí je napustio mongolske stepe i krenuo u srednju Aziju, gdje je osnovao carstvo Zapadni Liao. Na stepi nije uspostavljen mir jer su plemena, uključujući i Mongole pod vodstvom Kabul-kana, otkazala poslušnost Džurčenima (Biran, 2005: 26-32; Дробышев, 2010: 120; E Лун-ли, 1979: 279; Гумилев, 2004: 114-123; Крадин, 2011: 166-167; Кызласов, 1975: 176; Ларичев, 2007: 131-132, 316-321; Мote, 1999: 205; Пиков, 1989: 63-69; Пиков, 2001; Sinor, 1998: 234-236; Воробьев, 1975: 336).

\section{MONGOLI I CARSTVO JĪN}

Tradicionalna kineska historiografija ovoga razdoblja proširila je na plemena s područja suvremene Mongolije uopćeni naziv Tatari, koje su dijelili na tri skupine - Crni Tatari (Hēi Dádá 黑鞋靼), Bijeli Tatari (Bái Dádá 白鞋靼) i Divlji Tatari (Shēng Dádá 生鞋靼). Etnonim Bijeli Tatari odnosio se na turkijsko pleme Wānggǔ (汪古) ili Önggüd, koji su u 12. stoljeću bili podanici carstva Jīn i obnašali graničarsku službu sjevernije od gorja Yīnshān (陰山). Divljim Tatarima nazvana su, vjerojatno, lovačka plemena sjevernih, šumskih područja. Ta plemena bila su etnički heterogena, s prevladavajućom mongolskom i tunguskom komponentom. Mongolsko-turkijska nomadska plemena nazvana su Crni Tatari. U tu skupinu ubrajala su se osnovna mongolska plemena. Nakon ujedinjenja mongolskoturkijskih plemena pod Džingis-kanovim vodstvom, u prvoj polovini 13. stoljeća kineska historiografija počela je mijenjati percepciju etničke pripadnosti nomadskih plemena i tada se umjesto općeg naziva Tatari uvodi naziv Mongoli. O tom procesu

91 Vladarska titula izvedena iz mongolske riječi gür - »velik, prostran, sveopći«. Tu titulu nosili su vladari carstva Zapadni Liao (kin. Xī Liáo 西遼; mong. Kara Kitad; per. Qarā Khitā’̄i 1140. - 1218.) (Wittfogel i Fêng, 1949: 431).

92 Sedam oblasti pripadalo je nomadskim Qìdānima. Zbog prodora Džurčena nomadska plemena iz različitih dijelova Mongolije prihvatila su vodstvo Dàshíja. Na kurultaju su prisustvovala plemena: Dàihuáng Shìwéi (大黃室韋), Dílà (敵刺), Wángjìlà, Cháchìlà (茶赤刺), Yěxǐ (也喜), Bígǔdé (鼻 古德), Nílà (尼刺), Dálàguāi (達刺乘), Dámillǐ (達密里), Mìrjì (密兒紀), Hézhǔ (合主), Wūgǔlǐ, Zǔbǔ, Pǔsùwán (普速完), Tánggǔ (唐古), Hūmǔsī (忽母思), Xīde (觅的) i Jiūérbì (紏而畢) (Biran, 2005: 28-29; Крадин, 2011: 166; Пиков, 1989: 68; Wittfogel i Fêng, 1949: 634). 
svjedoči Rašīduddīn kada kaže da su nakon uspona Mongola »druga plemena iz ovih područja također postala poznata pod njihovim imenom, tako da veliki dio Turaka sada nazivaju Mongolima« (Рашид ад-Дин, 1952, I, 1: 77). Predaja о uništenju Tatara u Tajnoj povijesti Mongola, prema mišljenju P. O. Rykina, nije stvarni događaj, već alegorija koja označuje uništenje »opće kategorije«, a ne »lokalne skupine« (de Rachewiltz, 2004, 1: 76-77; Fu et al., 2007: 285, 288, 290; Golden, 2009: 19; Гумилев, 2004: 100, 101, 102, 104; Jackson, 2009: 27; Коновалов, 1999: 119; Козин, 1941: 123-124; Кычанов, 1966: 270; 1980: 142; Мункуев, 1975: 45, 92-94; Ratchnevsky, 1991: 8; Рыкин, 2002: 62, 63, 69, 71, 72, 77; Скрынникова, 2005: 43; Воробьев, 1975: 332; Weiers, 1997: 27).

Nakon pada dinastije Liáo plemena mongolskih stepa sačuvala su samostalnost, ali su nominalno priznavala vrhovništvo novih vladara sjeverne Kine. Vodeću ulogu na stepi tridesetih godina 12. stoljeća preuzeli su Kereiti. Njihova dominacija prestala je početkom pedesetih, nakon smrti Marquz Buyuruq-kana, kojega su Tatari zarobili i predali Džurčenima. Aktivni odnosi Mongola i carstva Jīn počeli su početkom tridesetih godina, kada su Džurčeni na sjevernoj granici nomadima prodavali robove, koje su mijenjali za konje. Među kupcima robova bili su i Mongoli. Sjeverna granica Kine i u to je doba bila izložena pljačkaškim pohodima nomadskih plemena. Prvi mongolski napad zabilježen je 1135. i on je poslužio kao povod ${ }^{93}$ za dugotrajni rat između Mongola i carstva Jīn. Kako je carstvo Jīn bilo zaokupljeno sukobom s carstvom Južni Song, tom problemu nije bilo posvećeno dovoljno pozornosti i sukob je završio 1147. pobjedom Mongola. Prema mirovnom ugovoru, carstvo Jīn Mongolima je ustupilo 27 pograničnih utvrda sjeverno od rijeke Xīnínghé ${ }^{4}$ (西寧河), koja je određena za granicu. Nadalje, Džurčeni su bili obvezni svake godine opskrbljivati mongolskog vladara žitaricama i stokom. Mongolski vođa bio je priznat za vladara »zemlje Mengfu«, ali, nezadovoljan dobivenom titulom, proglasio se carem, osnivačem dinastije Zǔ-yuán huángdì (祖元皇帝). Kineski izvori mongolskog vladara nazivaju »Ao-lo Po-chi-lieh«, »Kholobo Jinye« i »Oron-beiru«, a većina povjesničara identificira ga s Kabul-kanom. U Tajnoj povijesti Mongola za Kabul-kana se kaže da je upravljao »svim Mongolima«. Uz njegovu vladavinu vezano je i stvaranje velikoga plemenskog saveza - Hamag Mongol $^{95}$ (mong.

93 Kod Rašīduddīna je zapisana druga verzija događaja koji su bili povod za izbijanje rata. Džurčeni su željeli uspostaviti dobre odnose s Mongolima, pa su na dvor pozvali Kabul-kana. U njegovu čast održana je svečanost i podijeljeni su darovi. Kada je Kabul sa svojom pratnjom napustio teritorij carstva, za njim je bila poslana potjera s ciljem njegova uhićenja i pogubljenja, kao potencijalno opasnog neprijatelja. Kabul-kan je bio uhićen, ali je uspio pobjeći iz zarobljeništva. Kada je k njemu stiglo drugo džurčensko poslanstvo, za osvetu je dao pogubiti poslanike i taj je događaj poslužio kao povod za rat (Рашид ад-Дин, 1952, I, 1: 104; 1952, I, 2: 35-36).

94 E. I. Kyčanov smatra da se ne može odrediti koja je to današnja rijeka. Neki autori smatraju da je riječ o rijeci Kerulen (Кычанов, 1980: 147; 1992: 156; Медведев, 1984: 164).

95 Druga verzija naziva glasi Hamag Mongol Ulus - »Država svih Mongola«, »Općemongolska 


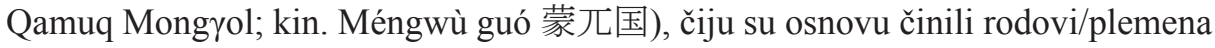
Kijat, Džalajir, Tajčut i Džirgin (mong. Jirgin; kin. Zhǐérīn 只舌児厅). Nakon Kabul-kana savezom je kratko upravljao Ambakaj-kan (mong. Ambaqai-qayan; kin. Ǎnbāhái-héhăn 俺巴孩中合罕), kojega je zarobilo tatarsko pleme Džujin (mong. J̌üyin; kin. Zhǔyīn 主因) i predalo Džurčenima. Prema Ambakanovoj želji, za novoga mongolskog vladara izabran je Kutula (mong. Qutula; kin. Hūtúlà 中忽圖 刺), sin Kabulov. Nakon izbora su Kutula-kan i Kadan-tajši (mong. Qadan'an-taisi; kin. Hédáān-tàizǐ 中合荅安太子) vodili trinaest neuspješnih pohoda na Tatare. Oko 1160. savez Hamag Mongol potpuno se raspao, vjerojatno zbog suparništva i borbi za vlast između članova vladajućeg roda. ${ }^{96}$ Nakon raspada saveza jedan od utjecajnijih vođa mongolskih plemena postao je Jesugej-batar, Džingis-kanov otac. Jesugej je nastavio borbu protiv Tatara, a pomogao je i Torilu (mong. To'oril; kin. Tuōwòlín 脫斡鄰, Tuōlǐ 脱里), članu kereitske vladajuće obitelji, u borbi za prijestolje. Godine 1171. kada se vraćao kući iz posjeta plemenu Olhunut, otrovali su ga Tatari. Većina rodova/plemena, od kojih su najznačajniji bili Tajčuti, tada je prestala priznavati vlast roda Kijat-Bordžigin. Jesugejeva udovica Helun-udžin (mong. Hö’lün-üjin; kin. Hēélún-wùzhēn 訶額侖元真), napuštena od podanika, ostala je sama sa svojom djecom i nekolicinom odanih ljudi. Njezin pokušaj da vrati podanike izazvao je napad tajčutskog vođe Tarkutaj-Kiriltuka (mong. Tarqutai-Kiriltuqa; kin. Tǎérhūtái-Q̌ilı̌lēitūhēi 塔児中忽台乞舌里勒秃黒) i zarobljavanje najstarijeg sina Temudžina ${ }^{97}$ (Allsen, 1994: 331-335; de Rachewiltz, 2004, 1: 10, 11, 13, $17-$ 18; Franke, 1994: 235, 238; Golden, 2009: 21; Grousset, 1970: 197-199; Гумилев, 2004: 110, 140, 148; Хойт, 2008: 31; Козин, 1941: 84, 85, 88; Кычанов, 1980: 146-147; 1997: 179; Кызласов, 1992: 156; Медведев, 1984: 162, 164; Ratchnevsky, 1991: 9-19, 24-28; Сандаг, 1977: 25-26; Tamura, 1973: 10-11; Ушницкий, 2011: 30; Воробьев, 1975: 118, 329-330; Weiers, 1997: 33).

U drugoj polovini 12. stoljeća razmještaj najvažnijih mongolsko-turkijskih plemena bio je sljedeći: osnovna mongolska plemena obitavala su u porječju Onona, Kerulena i Tuula. Sjeveroistočne oblasti Mongolije i Zabajkalje naseljavalo je pleme

država«. U kineskim izvorima naziva se »Država velikih Mongola«, »Velika mongolska država« (Dà Měnggǔ Guó 大蒙古國).

96 Prema drugoj verziji događaja, uzrok raspada mongolskog saveza bio je težak poraz 1161. od Tatara, saveznika džurčenskog cara Hǎilíng-wánga (海陵王 1150. - 1161.) (Golden, 1992: 285; Гумилев, 2004: 148; Воробьев, 1975: 331).

97 Rođen je između 1155. i 1167. u području zvanom Delun-boldag (mong. Deli’ün-boldaq; kin. Diélǐwēn-bèilēidáhé 迭里温孛勒荅中合) na rijeci Onon. R. P. Hrapačevskij smatra da se to područje nalazi u gorju Hèntèj (mong. Khentij nuruu) gdje izvire Onon. Ime je dobio po tatarskom vođi Temudžin-Uge (mong. Temüjin-Üge; kin. Tiēmùzhēn-Wùgé 帖木真元格), kojega je zarobio njegov otac. Riječ temü̈jin/temöjin na srednjemongolskom je značila »kovač« (de Rachewiltz, 2004, 1: 13; Храпачевский, 2004: 49-65; Козин, 1941: 85; Мункуев, 1975: 95). 
Urjanhaj. ${ }^{98}$ Bračni partneri roda Kijat-Bordžigin, iz kojega je potekao Džingis-kan, bilo je pleme Olhunut, ${ }^{99}$ koje je živjelo u jugoistočnoj Mongoliji. Tajčuti, jedna od važnijih skupina Mongola, koja je istupila iz saveza Hamag Mongol, obitavala je uz rijeku Onon. U području jezera Dalaj-nuur i Bujr-nuur (kin. Bèi’ěr Hú 貝 爾湖) ${ }^{100}$ živjeli su Tatari. ${ }^{101}$ Donji tok rijeke Orhon i porječje Selenge naselili su Merkiti. ${ }^{102} \mathrm{Na}$ predgorju Hangaja, uz rijeke Kerulen, Orhon i Tuul, čergarili su Kereiti. ${ }^{103}$ Područje zapadne Mongolije, od rijeke Orhon do Crnog Irtiša, zauzimali

98 Rašīduddīn ih ubraja među ona plemena koja su izašla iz Ergune-kuna. Mongoli su razlikovali »šumske« $\mathrm{i}$ »stepske« Urjanhaje. Potonji su obitavali uz rijeku Onon i bili podanici BordžiginMongola. Predaja u Tajnoj povijesti Mongola navodi pleme Džarčut-Urjanhaj (mong. Jarči’utUriangqai; kin. Zháérchìwùlēi-Wùliánghézhēn 札児赤元勒无良合真) na planini Burkan Kaldun (kin. Bùérhăn Hélēidūn 不児中罕中合勒敦), svetome mjestu Bordžigina. U literaturi postoje različita mišljenja o njihovu etničkom porijeklu. Neki autori smatraju kako postoje opravdani razlozi da ih se poveže s precima Južnih Tunguza, koji su migrirali iz Mandžurije. Pristaše tunguskog porijekla etnonim izvode iz riječi oron, »jelen «, ili urènkèn, »stanovnik planinske tajge« (UrayKöhalmi, 2002: 257, 258, 260; Ушницкий, 2008: 72-74; 2010: 96, 98-99).

99 Iz toga je plemena bila Helun-udžin, Džingis-kanova majka.

100 Jezero u istočnoj Mongoliji, na granici s kineskom pokrajinom Unutarnja Mongolija.

101 Etnopolitičku povijest srednjoazijskih stepa Rašīduddīn je podijelio na tri razdoblja. U drugom razdoblju, koje je trajalo do početka tatarsko-mongolskih sukoba u 12. stoljeću, Tatari su pokorili znatni dio turkijskih plemena. Iako su bili razjedinjeni i međusobno su ratovali, uspjeli su pokoriti sva plemena i oblasti »do granica Kine«. Etnonim Tatar, koji su prihvatila mnoga turkijska plemena, postao je opći politonim za nomade i bio je od 10. do 12. stoljeća dobro poznat u Kini, Srednjoj Aziji i Iranu. Stoga je Mạ̣mūd al-Kāšğarī (11. stoljeće), opširno područje između sjeverne Kine i istočnog Turkestana, nazvao »tatarskom stepom《. Rašīduddīn je zapisao da postoji šest različitih skupina Tatara i svaka ima svoju vojsku i vladara, a najvažnija je skupina Tutuqli'ut. Kada su Mongoli u 13. stoljeću osvojili Srednju Aziju, u turkijskim i islamskim krugovima, kao i u Kini, nazvani su Tatarima. Taj turkijski naziv za Mongole bio je prihvaćen ne samo u Srednjoj Aziji i na Bliskom istoku već i u istočnoj i zapadnoj Europi, iako Mongoli sami sebe nikada nisu nazivali Tatarima (Golden, 2009: 19; Кляшторный, 1993: 139-140, 144-145; Кляшторный і Савинов, 2005: 143-144, 148).

102 U kineskim izvorima etnonim se pojavljuje u oblicima Mìrjì (密兒紀), Mièlǐqũ (亦裡乞), Méilǐjí ( 梅里急), Mièlǐjí (滅裡吉), Mòérjí (默而吉) i Màiérjí (邁而吉). Dijelili su se na tri ogranka: Uduit-Merkiti, Uvas-Merkiti i Asahan-Merkiti. Njihova etnička pripadnost nije pouzdano utvrđena. U literaturi se javljaju teorije o mongolskome, turkijskom, tungusko-mandžurskom i paleosibirskom porijeklu. Jakutski povjesničar V. V. Ušnickij smatra ih potomcima tunguskih plemena Mòhé. Neki autori etnonim izvode iz mongolske riječi mergen - »dobar strijelac; mudar, razborit« (Цыбиктаров, 2001: 205; Ушницкий, 2009а: 212-219; 2013: 191-194).

103 Prema Rašīduddīnu, Kereiti su činili savez od šest plemena - Kereit, Džirkin, Konkait, Sakait, Tumatu i Albat. Plemena su bila mješovitoga etničkog porijekla - mongolskog i turkijskog, a povezivala ih je zajednička vjera - nestorijansko kršćanstvo. U kineskim izvorima nazivaju se Kèlièyí (克烈夷), Qièliè (怯烈), Qièlǐyì (怯里亦), Kèlièyìdàng (客列亦愓) i Kăiliè (凱烈). Etnonim je, prema jednom tumačenju, izveden od mongolske riječi kerij-e(n) - »gavran« (Рашид ад-Дин, 1952, I, 1: 128-129; Ушницкий, 2011: 30-33). 
su Najmani. ${ }^{104}$ Između rijeke Angare i Jeniseja u području tajge živjeli su Ojrati, ${ }^{105}$ »ljudi iz šume«. Navedena plemena bila su krajem 12. stoljeća sudionici važnih političkih događaja, koji su u konačnici doveli do ujedinjenja plemena i stvaranja Mongolskog Carstva (Golden, 1992: 285; 2009: 21-24; Grousset, 1970: 190-192; Хойт, 2008: 27-29; Ratchnevsky, 1991: 1-5; Ушницкий, 2009b: 14; Викторова, 1980: 171).

\section{DŽINGIS-KAN, TORIL-KAN I DŽAMUKA -SAVEZNICI I PROTIVNICI}

Djelovanje različitih procesa, političkih, demografskih, migracijskih i klimatskih, ${ }^{106}$ pokrenulo je u drugoj polovini 12. stoljeća ekspanziju mongolskih plemena. Gotovo neprekidni sukobi zbog otimanja ljudi, stoke i pašnjaka, zahtijevali su pojavu energičnog vođe koji će svojim autoritetom ujediniti sukobljena plemena. Ujedinjenje i jaka centralna vlast, nakon razdoblja razjedinjenosti, bili su jamstvo sigurnosti od međuplemenskih sukoba i ekspanzije južnijih sjedilačkih naroda. Posljednja dva desetljeća 12. stoljeća u povijesti Mongolije obilježila je borba dvojice plemenskih starješina Temudžina i Džamuke (mong. J̌amuqa; kin.

104 Smatra se da je etnonim povezan s mongolskim brojem naiman - »osam «, što implicira postojanje saveza osam plemena, koja su bila različitoga etničkog porijekla. Osnovu saveza najvjerojatnije su činila turkijska plemena. Neki autori povezuju ih s turkijskim plemenskim savezom Sekiz-Oguz, koje je prije obitavalo na istom prostoru. U kineskim izvorima Najmani 12. i 13. stoljeća smatrani su srodnicima Önggüda i ubrajani među Bijele Tatare. Bili su pod velikim kulturnim utjecajem južnih susjeda Ujgura. Osobna imena i titule najmanskih vladara bili su staroturski - Buyruq-kagan

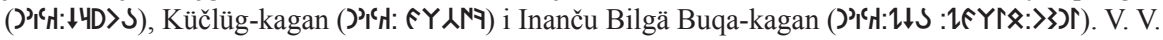
Ušnickij smatra da su Najmani dijelom bili mongolizirani Turci. U kineskim izvorima etnonim je zapisan u oblicima Năimă (乃馬), Năimăn (乃滿), Nàimàn (奈曼), Nàimán (奈蠻) i Nàimăn (耐 滿) (Murayama, 1958: 38; 1959: 190, 192-193, 197; Ушницкий, 2009b: 14-15, 20; 2011: 28, 29 , 30).

105 Vjerojatno opći naziv za dio plemena koji su poznati kao »šumski narodi«. Prema istraživanju D. V. Cybikdoržieva, porijeklo Ojrata povezano je s nastankom plemena Dörben. Do 13. stoljeća u ojratski savez ulazila su plemena Hojt, Dörben i Ölöt. Godine 1207. Kutuka-beki (kin. Hūdōuhébiéqǐ 中忽都中合別乞), vođa Tümen-Ojrata, priznao je Džingis-kanovu vlast. Nakon toga u ojratski savez ušla su i druga plemena »šumskih naroda«. Rašīduddīn je područje u kojem žive Ojrati nazvao Sekiz-muren - »Osmorječje«, koje se u literaturi poistovjećuje s porječjem Malog Jeniseja. Etnonim Ojrat izveden je od mongolskih riječi oi - »šuma« i arad - »narod« (Цыбикдоржиев, 2012: 121, 126, 133, 136, 147; Цыремпилов, 1996: 98, 100; de Rachewiltz, 2004, 1: 164; Козин, 1941: 174; Рашид ад-Дин, 1952, I, 1: 118-119; Зориктуев, 2000: 120).

106 Paleoklimatološka istraživanja u Mongoliji pokazala su značajne klimatske promjene krajem 12. stoljeća. Između 1180. i 1215. u stepama srednje i istočne Mongolije došlo je do većeg zahladnjenja. Istovremeno je istok zemlje pogodila dugotrajna suša. Pad temperature od nekoliko Celzijevih stupnjeva, u odnosu na sadašnjost, imao je negativne posljedice za ekosustav i posebno stočarstvo. Neki autori smatraju kako su upravo klimatske promjene pokrenule mongolska plemena prema jugu i jugozapadu (Jenkins, 1974: 220, 222, 225; Клименко, 2009: 325). 
Zhámùhé 札木合) ${ }^{107}$ za ujedinjenje mongolskih plemena. Taj proces nije bio samo borba za općemongolsko prijestolje već i borba različitih etnosa, među kojima su prevladavali Kereiti, za uspostavu vlasti na mongolskoj stepi. Nakon stvaranja Džingis-kanove države nastavljen je aktivni razvoj ujedinjenja i mongolizacije, dok je zaustavljen samostalni razvoj drugih etnosa.

Politički uspon Temudžin je započeo kao vazal kereitskog Toril-kana. Kada su Merkiti napali Temudžinov tabor i zarobili njegovu ženu Borte-udžin (mong. Börte-üjuin; kin. Bèiértiē-wùzhēn 孛舌児帖无真), Toril-kan je odlučio stupiti u pohod, uz uvjet da u njemu sudjeluje i Džamuka. Razbijeni Merkiti bježali su niz rijeku Selengu, Temudžin je vratio ženu, a saveznici su dobili bogati plijen i robove. Prema Rašīduddīnu, pohod na Merkite dogodio se 1177./1178. Nakon merkitskog pohoda Temudžin i Džamuka zajedno su oko dvije godine upravljali Mongolima. Kada je Temudžin, kako navodi Rašīduddīn, osnovao vlastiti ulus, ${ }^{108}$ odvojio se od Džamuke. Dio mongolske aristokracije, među njima i potomci mongolskih kanova, priključio se Temudžinu. ${ }^{109}$ Nakon određenog vremena, kada je njegov autoritet u stepi porastao, najvjerojatnije 1189./1190., bio je proglašen kanom i dobio titulu Džingis-kan ${ }^{110}$ (mong. Činggis-qa'an; kin. Chéngjísī-héānè 成吉思合阿訥, Chéngjísīhán 成吉思汗). Uskoro je izbio i prvi sukob između Džingis-kana i Džamuke u Dalan-baldžudadu (mong. Dalan-balǰutu; kin. Dálán-

107 Starješina plemena Džalajir, koji je u djetinjstvu postao anda - »pobratim « - s Temudžinom. Kada je počela borba za ujedinjenje, Džamuka je imao podršku većine mongolskih plemena. Bio je vazal kereitskog Toril-kana.

108 Izvorno staroturski (IJ ) - »zemlja, oblast«. Kod srednjovjekovnih Mongola termin ulus označivao je određenu političko-teritorijalnu formaciju, ali i ljudstvo koje je čergarilo na određenom području. U nomadskim zajednicama općenito je ljudstvo bilo važnije od teritorija i zato su odvođenje, odlazak ili gubitak ljudi značili propast ulusa (Кычанов, 1995: 368; 1997: 186; Владимирцов, 1934: 97, 101).

109 U Tajnoj povijesti Mongola navode se rodovi i plemena čije je ljudstvo djelomice ili u cijelosti pristupilo Temudžinu: Džalajir, Tarkud (kin. Tǎérhūdūn 塔舌児中忽敦), Čanšigut (kin. Chăngshīwùtì 做失元惕), Barulas (kin. Bălǔlàsī 把舌魯刺思), Mangud (kin. Mánghūdá 忙中忽荅), Arulad (kin. Ālǔlàdá 阿舌魯刺荅), Urjanhaj, Besüd (kin. Biésùdiéchě 別速迭扯), Suldus (kin. Sùlēidōus 速勒 都撒), Kongotan (kin. Huànghuōtăn 中晃中豁壇), Sükeken (kineski: Sùkèkènè 速客客訥), O1hunut, Korolas (kin. Huōluólàs 中豁舌羅刺撒), Dörben, Ikires, Noyakin (kin. Nàyáqín 那牙勤), Oronar (kin. Wòluónàér 斡舌羅納児), Barin (kin. Bāālín 巴阿舌鄰), Geniges (kin. Génígésī 格泥 格思), Undžin (mong. Ünǰin; kin. Wēnzhēn 温真), Sakajit (kin. Sāhéyìtì 撒中合亦惕) i Džurkin (mong. Jürkin; kin. Zhǔérqín 主舌児勤) (de Rachewiltz, 2004, 1: 46-48; Козин, 1941: 107-108).

110 Bliski suradnici Temudžina Altan-otčigin (kin. Ālēitán-wòtìchìjīn 阿勒壇斡惕赤厅), Kučar-beki (mong. Qučar-beki; kin. Hūcháér-biéqǔ 中忽察舌児別乞) i Sača-beki (kin. Sāchá-biéqũ 撒察別 乞) inicirali su tu važnu političku odluku. Smisao te titule, koju je Temudžin primio dvaput, nije do kraja razjašnjen. U historiografiji prevladava mišljenje kako Činggis znači »nebo«, a smisao titule bio bi »nebeski kan«, »kan imenovan Nebom« ili »sin Neba«. Neki autori smatraju da je riječ »džingis« varijanta turkijske riječi tengis - »ocean« i titula džingis-kan znači »ocean-kan «, u smislu - vladar svijeta (Golden, 1992: 286; Кляшторный і Султанов, 2009: 213; Кычанов, 1997: 206; Morgan, 2007: 54; Щербак, 1997: 155). Pregled izvora i ostalih teorija vidi u Панкратов, 1989: 180-186; Дугаров, 1996: 101-106. 
bālēizhǔtì 荅闌巴勒主惕) na gornjem toku Onona. Većina autora smatra kako je bitka, unatoč proturječnim izvorima, završila Džingis-kanovim porazom i njegovim privremenim povlačenjem iz aktivne borbe (Allsen, 1994: 335-337; Bira, 1998: 247-248; Christian, 1998: 390-392; de Rachewiltz, 2004, 1: 34-54; Grousset, 1970: 201-202; Гумилев, 2004: 154; Храпачевский, 2004: 74-91; Козин, 1941: 98-112, Кычанов, 1995: 369-370; Ratchnevsky, 1991: 31-47; Сандаг, 1977: 28; Зориктуев, 2011а: 81).

Zbog sve većeg pritiska nomadskih plemena na sjevernu granicu carstvo Jīn poduzimalo je do kraja 12. stoljeća različite obrambene mjere (Воробьев, 1975: 123). Jedna od prvih bila je zabrana izvoza željeza ${ }^{111} \mathrm{u}$ stepu, a od sredine 12 . stoljeća džurčenski carevi počeli su u pograničnim mongolskim stepama provoditi politiku »reduciranja punoljetnih«. Svake treće godine njihova je konjica provaljivala u istočnu Mongoliju s ciljem istrebljenja ili odvođenja u ropstvo muškog stanovništva. Odgovor nomada često je bio razaranje pograničnih oblasti džurčenskog carstva. Velike probleme carstvu su stvarale provale Tatara, protiv kojih su poduzimane kaznene ekspedicije. Džurčenski car Zhāngzōng (章宗 1189. - 1208.) poslao je 1196. vojskovođu Wángjīng-chéngxiànga (王京丞相) u pohod protiv tatarskog starješine Megudžin-sulta (mong. Megüj̆in-se'ülttü; kin. Miègǔzhēn-xuēwùlēitú 箩古真薛元勒圖), koji je prekršio mirovni sporazum. Tatari su bili razbijeni na rijeci Kerulen i bježali su niz rijeku Ulǰa ${ }^{12}$ (kin. Wúleizhá 浯勒札). Džurčenski zapovjednik, koji ih je slijedio, pozvao je Toril-kana i Džingis-kana na zajedničku akciju. Nakon izvojevane pobjede Džingis-kan je od džurčenskih vlasti dobio titulu ja'ut-quri ${ }^{113}$ (kin. zháwùtì-hūlǐ 札元惕中忽舌里), a Toril titulu ong (kin. wáng 王) i od tada se počeo nazivati Ong-kan. Novi pohod u istočnu Mongoliju carstvo Jīn organiziralo je 1198. protiv Olhunuta i drugih tatarsko-mongolskih plemena. No zbog unutarnjih sukoba vanjskopolitička aktivnost carstva počela je slabjeti. To je omogućilo Džingis-kanu da počne učvršćivati svoj položaj u istočnoj Mongoliji. Uskoro su se dogodile promjene u zapadnoj Mongoliji, gdje se najmanski ulus raspao na dva dijela pod vodstvom Tajan-kana (kin. Tăyáng-hăn 塔陽中罕) i Bujruk-kana (mong. Buyiruq-qan; kin. Bùyìŭhēi-hăn 不亦舌魯黒中罕). Zajedničkom akcijom Ong-kana, Džamuke i Džingis-kana, s prešutnim Tajan-kanovim odobrenjem, 1198./1199. Bujruk-kan je poražen. Nakon odluke o pohodu na Tajčute došlo je do raskola među saveznicima jer je Džamuka s Merkitima podržao Džingis-kanove

111 Mongolska plemena osjećala su kronični deficit željeza, neophodnog za izradu oružja. U vrijeme dinastije Jīn nije postojao strogi nadzor izvoza željeza u stepu. Štoviše, činovnici zaduženi za nadzor izvoza često su ignorirali propise. U stepu je stizala velika količina metalnog novca, koja se pretvarala u oružje (Дробышев, 2011: 9).

112 Suvremeni naziv Wūlēijí (乌勒吉), rijeka u Unutarnjoj Mongoliji.

113 Titula koju je imao zapovjednik manje vojne postrojbe (de Rachewiltz, 2004, 1: 57). 
protivnike. Džingis-kan je na rijeci Onon razbio Tajčute, dok se Ong-kan sukobio s Džamukom i Merkitima. Na kraju 12. stoljeća u mongolskoj stepi egzistirali su sljedeći plemenski savezi: Ong-kanovi Kereiti; Džingis-kanovi Mongoli; Džamuka kao vođa mnoštva manjih rodova i plemena, koji su u njemu vidjeli svoju sigurnost od ugroze većih saveza; Tajan-kanovi savezi Tatara i Najmana. Odnosi među savezima bili su vrlo nestabilni i postojala je realna opasnost njihova brzog raspada (Allsen, 1994: 337-339; Christian, 1998: 393; de Rachewiltz, 2004, 1: 56-57; Grousset, 1970: 203-206; Гумилев, 2004: 143-144; Хойт, 2008: 31-32; Храпачевский, 2004: 95-101; Jackson, 2009: 29; Козин, 1941: 113; Кычанов, 1995: 371; Morgan, 2007: 53; Рашид ад-Дин, 1952, I, 1: 112-113; Ratchnevsky, 1991: 5, 49, 52-53; Сандаг, 1977: 29-30).

\section{DŽINGIS-KANOVA POBJEDA I UJEDINJENJE PLEMENA}

Završno razdoblje borbe za prevlast u mongolskoj stepi počelo je 1201. (Храпачевский, 2004: 102). Džamuku su tada njegovi pristaše, ${ }^{114}$ na mjestu gdje se rijeka Kan (kin. Kān 刊) ulijeva u Argun, proglasili gur-kanom. Snage okupljene oko Džamuke otvoreno su proglasile neprijateljima Ong-kana i Džingis-kana. U području Kojten (mong. Köyiten; kin. Kuòyìtián 闊亦田), negdje oko jezera Bujrnuur, Ong-kan i Džingis-kan izvojevali su veliku pobjedu. Dio poraženih plemena uspio se spasiti bijegom - Ojrati su migrirali u dolinu rijeke Šisgis, Merkiti prema rijeci Selengi i području Bargudžin-Tokum, Najmani preko južnog Altaja prema Ulug Tagu (kin. Wùlǔhēi Tăhēi 兀魯黒塔黒), a Džamuka niz rijeku Ergunu. Tajčute, koji su bježali niz rijeku Onon, porazio je Džingis-kan i pripojio njihov ulus. Sljedeći pohod, prvi samostalni, Džingis-kan je poduzeo ujesen 1202. protiv Tatara, jednoga od najjačih ulusa u Mongoliji. U bitki na Dalan-nemergesu ${ }^{115}$ (kin. Dálán-niēmùérgésī 荅闌捏木舌児格思) poražena su plemena Ča’a’an Tatar ${ }^{116}$ (kin. Cháāān Tătǎér 察阿安塔塔舌児), Alči Tatar (kin. Ālēichì Tătǎér 阿勒赤塔塔舌 児), Dutagut Tatar (mong. Duta’ut Tatar; kin. Dōutăwùtì Tătǎér 都塔元惕塔塔舌 児) i Alukaj Tatar (mong. Aluqai Tatar; kin. Ālǔhái Tătǎér 阿魯中孩塔塔舌児). Predaja zapisana u Tajnoj povijesti Mongola i kod Rašīduddīna govori o genocidu počinjenom nad Tatarima. Džingis-kanova pobjeda poremetila je odnos snaga i labavi savez s Ong-kanom dodatno je bio narušen. Nakon neuspjelog pokušaja učvršćenja saveza bračnim vezama Ong-kan se odlučio na pohod, koji su zagovarali

114 Tajna povijest Mongola navodi ova plemena: Kadagin (mong. Qadagin; kin. Hédájīn 中合荅厅), Saldžigut (mong. Salǰi’ut; kin. Sālēizhǐwùtì 撒勒只元惕), Dörben-Tatar (kin. Duǒérbiān-Tătǎér 架 児邊塔塔舌児), Dörben, Ikires, Onggirat, Horolas, Najman, Merkit, Ojrat i Tajčut (de Rachewiltz, 2004, 1: 62-63; Козин, 1941: 116).

115 Područje u blizini ušća rijeke Halhe u istočnoj Mongoliji (de Rachewiltz, 2004, 1: 567).

116 Iskrivljeni oblik mongolske riječi čaqān, cagaan - »bijeli«. Riječ je o plemenu Bijeli Tatari. 
njegov sin Nilka-Sengum (mong. Nilqa-Senggüm; kin. Nǐlēihé-Sāngkūn 你勒中合 桑昆) i Džamuka. Saznavši za namjere Kereita, Džingis-kan je odstupio prema izvoru rijeke Halhe. Nakon teškog poraza utaborio se s ostacima vojske kod jezera Baldžuna (mong. Baljuna-na’ur; kin. Bālēizhǔnà-nàwúér 巴勒渚納納浯舌児) i započeo je pregovore s Ong-kanom, kojega je i dalje priznavao za svoga »kanaoca«. Iznenadnim napadom na tabor Kereita 1203. u trodnevnoj bitki Džingis-kan je izvojevao potpunu pobjedu. Ong-kan i njegov sin Nilka-Sengum bježali su na zapad, prema najmanskom ulusu. U sukobu s najmanskim pograničnim odredom ubijen je kereitski kan, dok je Nilka-Sengum pobjegao u Ujgurski Kaganat. Kereiti su bili raseljeni među plemena Džingis-kanova ulusa, koji je tada praktično obuhvaćao cijelu istočnu i srednju Mongoliju (Allsen, 1994: 339-341; Christian, 1998: 393-394; de Rachewiltz, 2004, 1: 62-65, 70, 76, 84-110; Grousset, 1970: 206-212; Гумилев, 2004: 161-163; Хойт, 2008: 33; Храпачевский, 2004: 102112; Jackson, 2009: 29; Козин, 1941: 116-117, 120, 123, 127-142; Кычанов, 1995 : 371-372; Рашид ад-Дин, 1952, I, 1: 106; 1952, I, 2: 132-134, 251; Ratchnevsky, 1991: 61-83; Сандаг, 1977: 31-32; Зориктуев, 2000: 122).

Nakon tih događaja Džamuka je u borbi s Džingis-kanom za saveznike mogao imati samo Najmane. Prema Tajnoj povijesti Mongola, najmanski Tajankan odlučio se za aktivnu strategiju i započeo je rat s Džingis-kanom. U savezu s Džamukom okupio je šaroliku koaliciju, ${ }^{117}$ a namjeravao je pridobiti i Önggüde, kojima je uputio poslanika. Preko poslanika je zamolio ongudskoga kana da »bude njegova desna ruka« u borbi s Džingis-kanom. No kan Alakuš Digid Kuri (kin. Ālàhūshí Dejítì Hūlǐ 阿刺中忽石的吉惕中忽舌里) ne samo da je odbio postati »desna ruka Najmana« u predstojećem sukobu već je i Džingis-kana obavijestio o njihovim namjerama. Istovremeno, u proljeće 1204., Džingis-kan je zbog velikih gubitaka u kereitskom pohodu započeo preustroj vojske. ${ }^{118}$ Nakon provedene reforme Džingis-kanova je vojska u ljeto došla do granica najmanskog ulusa. Bitka, u kojoj su Najmani pretrpjeli potpuni poraz, odigrala se na planini Nahu-gun (mong. Naqu-kun; kin. Nàhū-kūn 納中忽中㞾). ${ }^{119}$ Tajan-kan je poginuo u boju, dok je njegov sin Kučuluk (mong. Güčülük; kin. Gǔchūlǔkè 古出魯克) s ostacima

117 Prema podacima iz Povijesti dinastije Yuan, u koaliciju su ušla plemena Merkit, Kereit, Ojrat, Dörben, Kadagin, Tatar i Saldžigut (Храпачевский, 2004: 113).

118 Mongolska vojska bila je ustrojena po dekadskom principu - osnovane su postrojbe od tisuću (minqa[n]=mingqa[n]), sto (ja'un) i deset (harban) vojnika, a imenovani su i zapovjednici (noyan). Poslije, kada se povećao broj vojnika, osnovane su i postrojbe od 10.000 ljudi - tümen. Nadalje, Džingis-kan je osnovao osobnu gardu kešik (kin. kèshīkè 客失克), koja se dijelila na turqa'ut (kin. tǔérhéwùtì 土児合元惕) - dnevna garda i kebte ’ül (kin. kèbǔtiēwùlēi 客卜帖元勒) - noćna garda. Uvedena je dvorska služba čerbi (kin. chěérbì 扯児必), koja je dodijeljena šestorici bliskih kanovih suradnika (Allsen, 1994: 343, 345; de Rachewiltz, 2004, 1: 113-114, 445; 2004, 2: 689, 691; Козин, 1941: 144).

119 Raspravu o lokaciji planine vidi u de Rachewiltz, 2004, 2: 703. 
vojske bježao prema zapadu. Džadarani, Kadagini, Saldžiguti, Dörbeni, Tajčuti, Onggirati i pripadnici ostalih plemena, koji su slijedili Džamuku, predali su se Mongolima. Ujesen 1204. Džingis-kan je pripojio i ulus Merkita. Merkitski vođa Togtoa-Beki (mong. Toqto’a-Beki; kin. Tuōhēituōā-Biéqǐ 脫惕黒脫阿別乞), koji se spasio bijegom, ujedinio se s ostacima Najmana. U proljeće 1205. Džingis-kan je na zapadnim obroncima Altaja napao Kučuluka i Togtoa-Bekija. Merkitski je vođa ubijen, a ostaci Merkita pobjegli su u zemlju Karluka i Kipčaka, dok je najmanski Kučuluk-kan spas pronašao u carstvu Zapadni Liao. ${ }^{120}$ Nakon tih događaja većina ljudstva Džamuke prešla je na Džingis-kanovu stranu. Džamuka je ostao s malom skupinom ljudi, koji su ga ubrzo izručili Džingis-kanu. Tako je završilo nemirno razdoblje u povijesti Mongolije, kada su, prema riječima jednoga od bliskih Džingis-kanovih ljudi, »stalno jedan drugoga pljačkali«. Završetkom rata u stepi Mongoli su započeli s vanjskom ekspanzijom. Na kraju 1205. izvršen je prvi napad na zapadna područja tangutskog carstva X̄̄ Xià, gdje je razoren niz manjih gradova i utvrda. Položaj vladara mongolske stepe Džingis-kanu je potvrdila skupština (kurultaj, mong. quriltai), predstavnika vladajućeg roda i plemstva, koja se u veljači/ožujku 1206. održala na izvoru rijeke Onon. ${ }^{121}$ Prema riječima Rašīduddīna, skupština je mongolskom vladaru »potvrdila uzvišenu titulu Džingis-kan«, a obred ustoličenja vodio je dvorski šaman Kokoču (mong. Kököčü; kin. Kuòkuòchū 闊 闊出). Tako je završila borba kanova i borba plemena - mongolskoga, kereitskog, najmanskog, tatarskog i merkitskog - za prevlast u Mongoliji. Istovremeno su se odvijali proces nastanka novog etnosa - srednjovjekovnih Mongola, potiskivanje iz Mongolije turkijskih etnosa i mongolizacija zemlje. Postupno je ta zemlja dobila ime pobjednika i nazvana je Mongolija, a etnosi koji su je naseljavali počeli su se nazivati Mongolima. U zemljama gdje se sačuvala predaja o nekadašnjoj moći Tatara za Mongole se i dalje upotrebljavao naziv Mongoli-Tatari ili Tatari (Allsen,

120 Najmanski vođa imao je važnu ulogu u završnom razdoblju povijesti carstva Zapadni Liao. Gurkan Yēlù Zhílǔgǔ (耶律直魯古 1177. - 1213.) srdačno je primio Kučuluka, koji je uskoro oženio njegovu kćer. Kada je 1210. izbio rat s Horezmijskim Carstvom (per. Hvārezmšāhījān نَاىهاشجزراون), Kučuluk se otvoreno pobunio protiv gurkana. U bitki kod grada Balasaguna gurkan je pobijedio Kučuluka, ali sljedeće je godine zarobljen. Yēlù Zhílǔgǔ zadržao je svoju titulu, dok je stvarna vlast u zemlji pripala Kučuluku. Kada je 1213. umro Yēlü Zhílǔgŭ, za novoga gurkana izabran je Kučuluk. Pod utjecajem svoje žene Kučuluk je počeo proganjati muslimane, koji su činili većinu stanovništva. Godine 1218. napao je grad Olmaliq, čiji je vladar priznavao vlast Mongola. Kao odgovor Džingis-kan je poslao vojskovođu Džebea (mong. J̌ebe; kin. Zhěbié 者別) s dvadeset tisuća vojnika. Kada je ušao na teritorij carstva Zapadni Liao, Džebe je proglasio vjersku slobodu i muslimani su počeli napadati Kučulukove vojne posade u gradovima. U bijegu pred Mongolima Kučuluk je bio uhvaćen i pogubljen u planinama Pamira (Biran, 2005: 74-86; Golden 2009: 13; Ларичев, 2007: 323; Пиков, 1989: 99-104; Sinor, 1998: 240-242).

121 Vlast mongolskoga kana, bez obzira na izbornu skupštinu, smatrana je osobnom. Ona je kanu bila darovana Vječnim Nebom, što joj je davalo legitimnost. Pod vlast kanu bili su Nebom dani svi narodi i nije bilo razlike između stvarne pripadnosti njegovu carstvu i potencijalne pripadnosti. U osvajanju svijeta kan se morao koristiti snagom (küc̈ü) i karizmom (suи) (Юрченко, 2006: 9). 
1994: 341-343, 349; Christian, 1998: 394-395; de Rachewiltz, 2004, 1: 110-126, 128-134; Grousset, 1970: 213-217; Гумилев, 2004: 164-165; Храпачевский, 2004: 113-118; Козин, 1941: 142-152, 154-158; Кычанов, 1995: 372-373; Рашид ад-Дин, 1952, I, 1: 137-138; 1952, I, 2: 150; Ratchnevsky, 1991: 83-90; Сандаг, 1977: 32-34).

\section{ZAKLJUČAK}

Kako smo vidjeli, pisani povijesni izvori i arheološka građa omogućuju pregled etnogeneze protomongolskih zajednica od razdoblja plemenskih saveza Róurán i Shìwéi. Krajem 6. i početkom 7. stoljeća, nakon pada Rouranskoga Kaganata i daljnjega razvoja shiweiskih plemena, formirala se etnička jezgra iz koje će se razviti srednjovjekovni Mongoli. U razdoblju kineske dinastije Táng, prema mišljenju mnogih autora, etnonim Mongol prvi se put pojavljuje u obliku Méngwù. Pleme Méngwù, u sastavu plemenskog saveza Shìwéi, obitavalo je u šumskim predjelima Mandžurije, najprije uz gornji tok Amura, a poslije uz rijeku Argun. Raš̄īuddīn područje uz rijeku Argun naziva Ergune-kun i ono se smatra pradomovinom Mongola. U drugoj polovini 1. tisućljeća pleme Méngwù bilo je etnički i lingvistički blisko povezano s tunguskim plemenima, dok ga predaja zapisana u Tajnoj povijesti Mongola povezuje s turkijskim plemenima. Od vanjskih čimbenika na pretke Mongola najviše su utjecali politički događaji na istoku velike euroazijske stepe i u Mandžuriji. Od 6. stoljeća stepom su vladali turkijski etnosi, koji su osnivali moćne kaganate, čiju su vlast priznavala i plemena u Mandžuriji. Osnivanjem carstva Liáo početkom 10. stoljeća, prestao je utjecaj Turaka u Mandžuriji i počeo je siloviti uspon Qìdāna.

Također, u literaturi postoje različita mišljenja o početku i uzroku migracija predaka Mongola iz pradomovine u stepe današnje Mongolije. Na migracije, koje su bile postupne i trajale više stoljeća, vjerojatno su najviše utjecali sukobi s okolnim plemenima i političke promjene u državama čiju su vlast priznavali. Izlaskom na stepu mongolska plemena počela su preuzimati nomadske navike od turkijskih plemena. Tada se u sjeveroistočnoj Mongoliji, području Trorječja, formirao osnovni savez mongolskih plemena, koji je vjerojatno bio sastavni dio saveza Zǔbǔ. Za razdoblje dinastije Liáo možemo reći da je bilo odlučujuće za ranu povijest Mongola. Osvajački pohodi koje su vodili Qìāni imali su za posljedicu širenje mongolskih plemena stepom. Migracije su potaknule i etničke procese u kojima su mongolska i turkijska plemena na prostoru mongolske stepe osnivala nove etnopolitičke saveze. No valja napomenuti kako je povijest mongolskih plemena za razdoblje dinastije Liáo slabo poznata. 
U 12. stoljeću, razdoblju dinastije Jinn, mongolska plemena postupno preuzimaju inicijativu na stepi. Sukladno običajima tradicionalne kineske historiografije Mongole i ostala nomadska plemena izvori toga razdoblja nazivaju uopćenim imenom Tatari. Prvi put Mongoli su imali značajniju ulogu na stepi sredinom 12. stoljeća, u vrijeme Kabul-kana. Raspadom mongolskog saveza šezdesetih godina stepom su ponovno zavladali moćniji plemenski savezi - Tatari, Kereiti i Najmani. Ponovni uspon mongolskih plemena počeo je pojavom roda Kijat-Bordžigin, iz kojega je bio Temudžin, budući Džingis-kan. Taj daroviti plemenski vođa polako je uz pomoć i zaštitu kereitskoga kana postao značajni čimbenik na mongolskoj stepi. Njegova pronicavost i odabir povoljnog trenutka omogućili su mu da se postupno riješi suparnika i nakraju samostalno zavlada mongolsko-turkijskim plemenima.

\section{LITERATURA}

Алкин, С. В. (2001). История изучения и современные представления о времени сооружения «вала Чингис-хана», u: А. М. Кузнецов (ur.). Широкогоровские чтения: (проблемы антропологии и этнологии). Материаль научной конференции посвященной 102 годовщине со времени образования ДВГУ, г. Владивосток 18-19 октября 2001 г. Владивосток: Издательство Дальневосточного университета, 60-63.

Allsen, T. (1994). The rise of the Mongolian empire and Mongolian rule in north China, u: F. Herbert i T. Denis (ur.). The Cambridge History of China. Vol. 6: Alien Regimes and Border States, 907-1368. Cambridge: Cambridge University Press, 321-413.

Ангархаев, А. Л. (2003). Этимологическое исследование древнемонгольских онимов. Новосибирск: Наука.

Асеев, И. В. (2009). Некоторые аспекты исторических и археологических материалов как свидетельства расселения монголоязычных племен в Байкальском регионе и Монголии в средние века, Вестник Новосибирского государственного университета. Серия: история, филология, 8 (5): 189-198.

Асеев, И. В., Кириллов, И. И. і Ковычев, Е. В. (1984). Кочевники Забайкалья в эпоху средневековья: (по материалам погребений). Новосибирск: Наука.

Бичурин, Н. Я. (1950). Собрание сведений о народах, обитавщих в Средней Азии в древние времена, tом II. Москва - Ленинград: Издательство Академии наук СССР.

Билэгт, Л. (2007). Раннемонгольские племена: (этногенетические изыскания на основе устной истории). Улаанбаатар: Академия наук Монголии, Институт истории.

Bira, S. (1998). The Mongols and their state in the twelfth to the thirteenth century, u: M. S. Asimov i C. E. Bosworth (ur.). History of Civilizations of Central Asia. Vol. IV: The Age of Achievement: A. D. 750 to the End of the Fifteenth Century. Part 1: The Historical, Social and Economic Setting. Paris: UNESCO Publishing, 243-259.

Biran, M. (2005). The Empire of the Qara Khitai in Eurasian History: between China and the Islamic World. Cambridge [etc.]: Cambridge University Press. 
Бутанаев, В. Я. і Худяков, Ю. С. (2000). История енисейских кыргыззов. Абакан: Издательство Хакасского государственного университета им. Н. Ф. Катанова.

Christian, D. (1998). A History of Russia, Central Asia and Mongolia. Vol. 1: Inner Eurasia from Prehistory to the Mongol Empire. Oxford: Blackwell Publishers.

Цэвээндорж, Д., Баяр, Д., Цэрэндагва, Я. і Очирхуяг, Ц. (2008). Археология Монголии. Улаанбаатар: Институт археологии Академии наук Монголии.

Цыбенов, Б. Д. (2009). О киданьской версии происхождения дагуров, Проблемы этнической истории и культуры тюрко-монгольских народов, 1: 5-13.

Цыбикдоржиев, Д. В. (2012). Ойраты до и после 1207 г., u: М. М. Содномпилова (ur.). Культурное наследие народов Центральной Азии. Bып. 3: Сборник статей. Улан-Удэ: Издательство БНЦ СО РАН, 120-148.

Цыбиктаров, А. Д. (2001). Бурятия в древности: история (с древнейших времен до ХVII века). 2. изд. Улан-Удэ: Издательство Бурятского госуниверситета (Серия "Бурятия", вып. 3).

Цыремпилов, В. Б. (1996). Об этимологии этнонимов монгол, хори, бурят и ойрат, u: А. Очир і Б. Р. Зориктуев (ur.). Монголо-бурятские этнонимы: сборник статей. Улан-Удэ: БНЦ СО РАН, 93-100.

Clauson, G. (1973). Philology and archaeology, Antiquity, 47 (185): 37-42, doi: 10.1017/ S0003598X00034657.

Чагдуров, С. Ш. (1999). Прародина монголов. Улан-Удэ: Издательство Бурятского госуниверситета.

Чимитдоржиев, Ш. Б. (1995). Сведения о бурятских племенах в “Сокровенном сказании монголов”, u: Б. З. Базарова і П. Б. Коновалов (ur.). “Тайная история монголов": источниковедение, история, филология. Новосибирск: Наука, 95-99.

Данилов, С. В. (1985). Жертвоприношения животных в погребальных обрядах монгольских племен Забайкалья, u: П. Б. Коновалов (ur.). Древнее Забайкалье и его культурные связи. Новосибирск: Наука, 86-91.

Дашибалов, Б. Б. (2005). На монголо-тюркском пограничье: (этнокультурные процессы в Юго-Восточной Сибири в средние века). Улан-Удэ: Издательство Бурятского научного центра СО РАН.

de Rachewiltz, I. (1997). A Note on the Word Börte in the Secret History of the Mongols, East Asian History, 13/14: 153-155.

de Rachewiltz, I. (2004). The Secret History of the Mongols. A Mongolian Epic Chronicle of the Thirteenth Century, sv. 1 i 2. Translated with a Historical and Philological Commentary by I. de Rachewiltz. Leiden - Boston: Brill Academic Publishers (Brill's Inner Asian Library, $7 / 1$ i $7 / 2$ ).

Деренко, М. В., Лункина, А. В., Малярчук, Б. А., Захаров, И. А., Цэдэв, Ц., Парк, К. С., Чо, Я. М., Ли, Х. К., Чу, Ч. X. et al. (2004). Рестрикционный полиморфизм митохондриальной ДНК у корейцев и монголов, Генетика, 40 (11): 1562-1570.

Деревянко, Е. И. (1981). Племена Приамурья, І тысячелетие нашей эры: очерки этнической истории и культуры. Новосибирск: Наука.

Дробышев, Ю. И. (2010). Политика киданей в Центральной Азии, и: С. И. Блюмхен (ur.). Общество и государство в Китае: XL научная конференция. Москва: Институт востоковедения РАН, 108-122.

Дробышев, Ю. И. (2011). Дочингисовы монголы и окружающая среда, Восток. Афроазиатские общества: история и современность, 5: 5-21. 
Drompp, M. R. (2002). The Yenisei Kyrgyz from Early Times to the Mongol Conquest, u: H. C. Güzel, C. C. Oğuz i O. Karatay (ur.). The Turks. Ankara: Yeni Türkiye Publications, 480-488.

Дугаров, Б. С. (1996). К вопросу о происхождении слова чингис, u: А. Очир і Б. Р. Зориктуев (ur.). Монголо-бурятские этнонимы: сборник статей. Улан-Удэ: БНЦ СО РАН, 101106.

Думан, Л. И. (1986). Проблемы внешней политики киданей в VII-Х вв. н. э., u: В. Е. Ларичев (ur.). Восточная Азия и соседние территории в средние века: история и культура Востока Азии. Новосибирск: Наука, 13-21.

Dunlop, D. M. (1944). The Karaits of Eastern Asia, Bulletin of the School of Oriental and African Studies, 11 (2): 276 - 289, doi: 10.1017/S0041977X00072463.

Е Лун-ли (1979). История государства Киданей (Цидань Го Чжи). Перевод с китайского, введение, комментарий и приложения В. С. Таскина. Москва: Наука.

Екеев, Н. В. (2010). К проблеме этнополитической истории алтайцев (X - середина XVIII вв.), Мир Евразии, 2: 34-42.

Franke, H. (1990). The forest peoples of Manchuria: Kitans and Jurchens, u: D. Sinor (ur.). The Cambridge History of the Early Inner Asia. Cambridge: Cambridge University Press, 400423.

Franke, H. (1994). The Chin dynasty, u: H. Franke i D. Twitchett (ur.). The Cambridge History of China. Vol. 6: Alien Regimes and Border States, 907-1368. Cambridge: Cambridge University Press, 215-320.

Fu, Y., Zhao, H., Cui, Y., Zhang, Q., Xu, X., Zhou, H. i Zhu, H. (2007). Molecular Genetic Analysis of Wanggu Remains, Inner Mongolia, China, American Journal of Physical Anthropology, 132 (2): 285-291, doi: 10.1002/ajpa.20450.

Gernet, J. (1990). A History of Chinese Civilization. Cambridge: Cambridge University Press.

Гоголев, А. И. (1993). К этнической истории средневекового Предбайкалья (якутскобурятские этнические связи), и: Б. Р. Зориктуев (ur.). Этническая история народов Южной Сибири и Центральной Азии. Новосибирск: Наука, 199-207.

Golden, P. B. (1990). The Karakhanids and early islam, u: D. Sinor (ur.). The Cambridge History of the Early Inner Asia. Cambridge: Cambridge University Press, 343-370.

Golden, P. B. (2009). Inner Asia c. 1200, u: N. Di Cosmo, J. F. Allen i P. B. Golden (ur.). The Cambridge History of Inner Asia: The Chinggisid Age. Cambridge: Cambridge University Press, 6-25.

Grousset, R. (1970). The Empire of the Steppes: A History of Central Asia. New Brunswick, N. J. - London: Rutgers University Press.

Гумилев, Л.Н. (2004). Поиски вымышленного иарства: Легенда о “государстве пресвитера Иоанна". Москва: Айрис-пресс.

Гумилев, Л. Н. (2005). Древние Тюрки. Москва: Айрис-пресс.

Гуркин, С. В. (2004). К вопросу о политических причинах миграции номадов из Азии в степи Восточной Европы в 20 - 40-е гг. XI в., Известия высших учебных заведений. Северо-Кавказский регион. Серия: общественные науки, 2: 40-46.

Hambis, L. (1970). L'histoire des Mongols avant Gengis-Khan d'après les sources chinoises et mongoles, et la documentation conservée par Rašīdu-'d-Dīn, Central Asiatic Journal, 14: $125-133$.

Хандсурэн, Ц. (1993). Жужаньское ханство, и: Б. Р. Зориктуев (ur.). Этническая история народов Южной Сибири и Центральной Азии. Новосибирск: Наука, 66-106. 
Haussig, H. W. (1966). Die Shuan-shuan, u: B. Spuler (ur.). Geschichte Mittelasiens. Leiden Köln: E. J. Brill, 118-120 (Handbuch der Orientalistik, Abt. 1. Bd. 5. Abschnitt 5).

Heršak, E. i Silić, A. (2002). Avari: osvrt na njihovu etnogenezu i povijest, Migracijske i etničke teme, 18 (2-3): 197-222.

Хойт, С. К. (2008). Кереиты в этногенезе народов Евразии: (историография проблемь). Элиста: Издательство Калмыцкого универзитета.

Храпачевский, Р. П. (2004). Военная держава Чингисхана. Москва: Издательство АСТ.

Худяков, Ю. С. (1989). Об этнической интерпретации средневековых памятников ЮгоЗападного Забайкалья, u: Т. М. Михайлов (ur.). Этнокультурные процессы в ЮгоВосточной Сибири в средние века: сборник научных трудов. Новосибирск: Наука, $27-34$.

Худяков, Ю. С. (1993). Расселение монгольских племен в Центральной Азии в конце I - начале II тысячелетия н.е., u: Б. Р. Зориктуев (ur.). Этническая история народов Южной Сибири и Центральной Азии. Новосибирск: Наука, 166-175.

Именохоев, Н. В. (1989). К вопросу о культуре ранних монголов, u: Т. М. Михайлов (ur.). Этнокультурные прочессы в Юго-Восточной Сибири в средние века: сборник научных трудов. Новосибирск: Наука, 55-62.

Именохоев, Н. В. (1992). Раннемонгольская археологическая культура, и: П. Б. Коновалов (ur.). Археологические памятники эпохи средневековья в Бурятии и Монголии: сборник научных трудов. Новосибирск: Наука, 23-48.

Jackson, P. (2009.) The Mongol age in Eastern Inner Asia, u: N. Di Cosmo, J. F. Allen i P. B. Golden (ur.). The Cambridge History of Inner Asia: The Chinggisid Age. Cambridge: Cambridge University Press, 26-44.

Janhunen, J. (1996). Manchuria: an Ethnic History. Helsinki: The Finno-Ugrian Society (Mémories de la Société Finno-Ougrienne, 222).

Jenkins, G. (1974). A Note on Climatic Cycles and the Rise of Chinggis Khan, Central Asian Journal, 18 (4): 217-226.

Юрченко, А. Г. (2006). Историческая география политического мифа: образ Чингис-хана в мировой литературе XIII-XV вв. Санкт-Петербург: Евразия.

Кадырбаев, А. Ш. (1984). “Юань ши” как источник по истории кереитов и найманов, и: Г. Ф. Гирс (ur.). Письменные памятники Востока: историко-филологические исследования. Ежегодник 1976-1977. Москва: Наука, 254-259.

Камалов, А. К. (2001). Древние уйгуры: VIII-IX вв. Алматы: “Наш Мир”.

Katoh, T., Batmunkh, M., Tounai, K., Mano, S., Ando, H., Oyungerel, G., Chae, G.-T., Han, H., Jia, G.-J., Tokunaga, K., Munkhtuvshin, N., Tamiya, G. i Inoko, H. (2005). Genetic features of Mongolian ethnic groups revealed by Y-chromosomal analysis, Gene, 346: 63-70, doi: 10.1016/j.gene.2004.10.023.

Клименко, В. В. (2009). Климат: непрочитанная глава истории. Москва: Издательский дом МЭИ.

Кляшторный, С. Г. (1993). Государства татар в Центральной Азии (дочингисова эпоха), u: В. М. Солнцев (ur.). Mongolica: k 750-летию “Сокровенного сказания”. Москва: Наука, 139-147.

Кляшторный, С. Г. (1995). Первый Тюркский каганат, u: Л. Б. Аблаев і К. З. Ашрафян (ur.). История Востока в шести томах. Том 2: Восток в средние века. Москва: Восточная литература РАН, 60-67. 
Кляшторный, С. Г. і Савинов, Д. Г. (2005). Степные империи древней Евразии. СанктПетербург: Филологический факультет Санкт-Петербургского государственного универзитета.

Кляшторный, С. Г. і Султанов Т. И. (2009). Государства и народы Евразийских степей: от древности к Новому времени. 3. изд., исправленное и дополненное. Санкт-Петербург: Петербургское Востоковедение.

Коновалов, П. Б. (1989). Корреляция средневековых археологических культур Прибайкалья и Забайкалья, u: T. М. Михайлов (ur.). Этнокультурные процессы в Юго-Восточной Сибири в средние века: сборник научных трудов. Новосибирск: Наука, 5-20.

Коновалов, П. Б. (1999). Этнические аспекты истории Центральной Азии: (древность и средневековье). Улан-Удэ: Издательство Бурятского научного центра СО РАН.

Ковычев, Е. В. (1981). Монгольские погребения из Восточного Забайкалья, и: П. Б. Коновалов (ur.). Новое в археологии Забайквлья. Новосибирск: Наука, 73-79.

Козин, С. А. (1941). Сокровенное сказание: монгольская хроника 1240 г. под названием

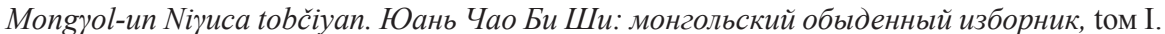
Москва - Ленинград: Издательство Академии наук СССР.

Крадин, Н. Н. (2007). Кочевники Евразии. Алматы: Дайк-Пресс.

Крадин, Н. Н. (ur.) (2011). Киданьский город Чинтолгой-балгас. Москва: Восточная литература РАН.

Крадин, Н. Н. і Ивлиев, А. Л. (2010). Бохайцы в Монголии в эпоху Ляо, и: А. П. Деревя́нко, А. Б. Куделин і В. А. Тишко́в (ur.). Адаптация народов и культур к изменениям природной среды, соииальным и техногеннылм трансформациям. Москва: РОССПЭН, 146-152.

Крадин, Н. Н., Ивлиев, А. Л. і Васютин, С. А. (2013). Киданьские города конца X - начала XI в. в Центральной Монголии и социальные процессы на периферии империи Ляо, Вестник Томского государственного университета. История, 2: 53-57.

Крюков, М. В., Малявин, В. В. і Софронов, М. В. (1979). Китайский этнос на пороге средних веков. Москва: Наука.

Кумеков, Б. Е. (1972). Государство кимаков IX-XI вв. по арабским источникам. Алма-Ата: Наука.

Кушкумбаев, А.К.(2009). Институт облавных охоти иоенноедело кочевников Центральной Азии: сравнительно-историческое исследование. Кокшетау: Келешек-2030.

Кычанов, Е. И. (1966). Чжурчжэни в ХІ в. (Материалы для этнографического исследования), u: А. П. Окладников (ur.). Материаль по истории Сибири. Древняя Сибирь, вып. 2. Новосибирск: Наука, 269-281.

Кычанов, Е. И. (1980). Монголы в VI - первой половине XII в., u: В. Е. Ларичев (ur.). Дальний Восток и соседние территории в средние века: (история и культура Востока Азии). Новосибирск: Наука, 136-148.

Кычанов, Е. И. (1995). Монголы и монгольское завоевание, u: Л. Б. Аблаев і К. З. Ашрафян (ur.). История Востока в шести томах. Том 2: Восток в средние века. Москва: Восточная литература РАН, 364-384.

Кычанов, Е. И. (1997). Кочевие государства от гуннов до маньчжуров. Москва: Восточная литература РАН.

Кызласов, Л. Р. (1975). Ранние монголы: (к проблеме истоков средневековой культуры), u: В. Е. Ларичев (ur.). Сибирь, Центральная и Восточная Азия в средние века. Новосибирск: Наука, 170-177 (История и культура востока Азии, III). 
Кызласов, Л. Р. (1992). Очерки по истории Сибири и Центральной Азии. Красноярск: Издательство Красноярского университета.

Ларичев, В. Е. (1980). Народы Дальнего Востока в древности и средние века и их роль в культурной и политической истории Восточной Азии, u: В. Е. Ларичев (ur.). Дальний Восток и соседние территории в средние века: история и культура Востока Азии. Новосибирск: Наука.

Ларичев, В. Е. (2007). История Железной империи. Новосибирск: Издательство Института археологии и этнографии СО РАН.

Малов, С. Е. (1951). Памятники древнетюркской письменности: тексты и исследования. Москва - Ленинград: Издательство Академии наук СССР.

Малов, С. Е. (1959). Памятники древнетюркской письменности Монголии и Киргизии. Москва - Ленинград: Издательство Академии наук СССР.

Медведев, В. Е. (1984). К вопросу о средневековой народности мэнгу, u: В. Е. Медведев (ur.). Археология юга Сибири и Дальнего Востока. Новосибирск: Наука, 162-166.

Мелихов, Г. В. (1977). Установление власти монгольских феодалов в Северо-Восточном Китае, u: С. Л. Тихвинский (ur.). Татаро-монгольв в Азии и Европе: сборник статей. 2. изд., переработанное и дополненное. Москва: Наука, 62-84.

Михайлов, Т. М. (1993). Развитие этнического самосознания монголов в XII-XIV вв., u: Б. Р. Зориктуев (ur.). Этническая история народов Южной Сибири и Центральной Азии. Новосибирск: Наука, 179-198.

Miyakawa, H. i Kollautz, A. (1968). Die Mongolei in der Epoche der Jou-Jan (5. und 6. Jhr. n. Chr.), Central Asiatic Journal, 12: 181-208.

Morgan, D. (2007). The Mongols. $2^{\text {nd }}$ ed. Malden - Oxford - Carlton: Blackwell Publishing.

Mote, F. W. (1999). Imperial China, 900-1800. Cambridge, Massachusetts - London: Harvard University Press.

Мункуев, Н. Ц. (1975). Мэн-да бэй-лу (“Полное описание монголо-татар”). Москва: Наука.

Murayama, S. (1958). The Language of the Naiman, Kereyit, Merkit and the Ongut, Transactions of the International Conference of Eastern Studies, 2: 38-39.

Murayama, S. (1959). Sind die Naiman Türken oder Mongolen, Central Asiatic Journal, 4 (3): $188-198$.

Нестеров, С. П. (1995). Северные шивэй в Приамурье, u: А. П. Забияко (ur.). Традиционная культура востока Азии: археология и культурная антропология, вып. І. Благовещенск: Издательство Благовещенского государственного педагогического института, 105-122.

Нестеров, С. П. (1998). Народы Приамурья в эпоху раннего средневековья. Новосибирск: Издательство Института археологии и этнографии СО РАН.

Нестеров, С. П. (2002). Пути и время миграции хэйшуй мохэ в Западное Приамурье, u: C. В. Алкин (ur.). История и культура Востока Азии: татериаль Международной научной конференции, Новосибирск, 9-11 декабря 2002 2, tом 1. Новосибирск: Институт археологии и этнографии СО РАH, http://www.sati.archaeology.nsc.ru/Home/pub/Data/ $\mathrm{LARYCH} /$ ?html=nest.htm\&id=1330 (2. 10. 2012.).

Нимаев, Д. Д. (1988). Проблемы этногенеза бурят. Новосибирск: Наука.

Нимаев, Д. Д. (1993). О средневековых хори и баргутах, u: Б. Р. Зориктуев (ur.). Этническая история народов Южной Сибири и Центральной Азии. Новосибирск: Наука, 144-166.

Очир, А. (1996). О происхождении этнических названий монгол, боржигин, хатагин, элжигин и цорос, u: А. Очир і Б. Р. Зориктуев (ur.). Монголо-бурятские этнонимы: сборник статей. Улан Удэ: БНЦ СО РАН, 3-8. 
Окладников, А. П. (1958). Археологические данные о появлении первых монголов в Прибайкалье, u: Г. Д. Санжеев (ur.). Филология и история монгольских народов: памяти академика Б. Я. Владимириова. Москва: Издательство Восточной литературы, 200-213.

Окладников, А. П. (1960). Бурхотуйская культура железного века в Юуго-Западном Забайкалье, u: Труды Бурятского комплексного научно-исследовательского института, вып. 3. Улан-Удэ: Бурятское книжное издательство, 16-30.

Панкратов, Б. И. (1989). Об этимологии “титула чингис”, u: Д. А. Ольдерогге (ur.). Cmpaнь и народы Востока. Вып. ХХVI: Средняя и иентральная Азия: география, этнография, история. Москва: Наука, 180-189.

Пэрлээ, Х. (1962). Киданьские города и поселения на территории Монгольской Народной Республики (X - начало XII в.), u: С. В. Киселёв (ur.). Монгольский археологический сборник. Москва: Издательство Академии наук СССР, 55-62.

Пэрлээ, Х. (1963). Собственно монгольские племена в период Киданьской империи (907-1125), u: Б. Г. Гафуров (ur.). Труды Двадиать пятого Международного конгресса востоковедов: Москва 9 -16 августа 1960. Том 5: Заседания секиий XVI-XX. Москва: Издательство Восточной литературы, 314-317.

Пиков, Г. Г. (1989). Западные кидани. Новосибирск: Издательство Новосибирского университета.

Пиков, Г. Г. (2001). Кидани и Сибирь, Сибирская Заимка, 6, http:// zaimka.ru/kochevie/ pikov1.shtml (12. 04. 2014.).

Потапов, Л. П. (1953). Очерки по истории алтайцев. Москва - Ленинград: Издательство Академии наук СССР.

Рассадин, В. И. (2009). О тюркском влиянии на сложение комплекса скотоводческой лексики монгольских языков, Учёные записки Забайкальского государственного гуманитарнопедагогического университета им. Н.Г. Чернышевского. Серия: филология, история, востоковедение, 3: 158-165.

Рашид Ад-Дин (1952). Сборник летописей, том I, кн. 1 і 2. Перевод с персидского Л. А. Хетагурова, редакция и примечания А. А. Семенова. Москва - Ленинград: Издательство Академии наук СССР.

Ratchnevsky, P. (1991). Genghis Khan: His Life and Legacy. Oxford, UK - Cambridge, USA: Blackwell Publishers.

Rybatzki, V. (2006). Genealogischer Stammbaum der Mongolen, u: E. V. Boikova i G. Stary (ur.). Florilegia Altaistica: Studies in Honour of Denis Sinor on the Occasion of His $90^{\text {th }}$ Birthday. Wiesbaden: Harrassowitz Verlag, 135-192.

Рыкин, П. О. (2002). Создание монгольской идентичности: термин “монгол” в эпоху Чингисхана, Вестник Евразии, 16 (1): 48-85.

Сандаг, Ш. (1977). Образование единого монгольского государства и Чингисхан, и: С. Л. Тихвинский (ur.). Татаро-монголье в Азии и Европе: сборник статей. 2. izd., переработанное и дополненное. Москва: Наука, 23-45.

Савинов, Д. Г. (1994). Государства и культурогенез на территории Южной Сибири в эпоху раннего средневековья. Кемерово: Кемеровский государственний университет.

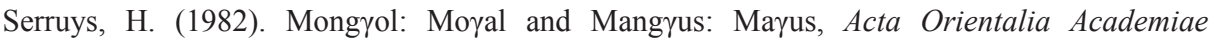
Scientiarum Hungaricae, 36 (1-3): 475-484.

Sinor, D. (1990). The establishment and dissolution of the Türk empire, u: D. Sinor (ur.). The Cambridge History of the Early Inner Asia. Cambridge: Cambridge University Press, 285316. 
Sinor, D. (1998.) The Kitan and the Kara Khitay, u: M. S. Asimov i C. E. Bosworth (ur.). History of Civilizations of Central Asia. Vol. IV: The Age of Achievement: A. D. 750 to the End of the Fifteenth Century. Part 1: The Historical, Social and Economic Setting. Paris: UNESCO Publishing, 227-242.

Sinor, D. i Klyashtorny, S. G. (1996). The Türk Empire, u: B. A. Litvinsky (ur.). History of Civilizations of Central Asia. Vol. III: The Crossroads of Civilizations: A. D. 250 to 750. Paris: UNESCO Publishing, 326-347.

Sinor, D., Shimin, G. i Kychanov, Y. I. (1998). The Uighurs, the Kyrgyz and the Tangut (eighth to the thirteenth century), u: M. S. Asimov i C. E. Bosworth (ur.). History of Civilizations of Central Asia. Vol. IV: The Age of Achievement: A. D. 750 to the End of the Fifteenth Century. Part 1: The Historical, Social and Economic Setting. Paris: UNESCO Publishing, str. 191-214.

Скрынникова, Т. Д. (2005). Две Монголии: особенность средневековых идентификационных практик, Вестник Евразии, 28 (2): 29-65.

Somers, R. M. (1979). The end of the T'ang, u: D. Twitchett (ur.). The Cambridge History of China. Vol. 3: Sui and T'ang China, 589-906, part 1. Cambridge: Cambridge University Press, 682-789.

Spuler, B. (1966). Geschichte Mittelasiens seit dem Auftreten der Türken, u: B. Spuler (ur.). Geschichte Mittelasiens: Handbuch der Orientalistik, Bd. 5, Abschnitt 5. Leiden - Köln: E. J. Brill, 123-310.

Сухбаатар, Г. (1996). Монгольские этнонимы дочингисовой эпохи, u: А. Очир і Б. Р. Зориктуев (ur.) Монголо-бурятские этнонимы: сборник статей. Улан-Удэ: БНЦ СО PAH, 68-76.

Шавкунов, Э. В. (1968). Государство Бохай и памятники его культуры в Приморье. Ленинград: Наука.

Щербак, А. М. (1966). О характере лексических взаимосвязей тюркских, монгольских и тунгусо-маньчжурских языков, Вопросы языкознания, 3: 21-35.

Щербак, А. М. (1986). Тюркско-монгольские языковые связи (К проблеме взаимодействия и смешения языков), Вопросы языкознания, 4: 47-59.

Щербак, А. М. (1997). Ранние тюркско-монгольские языковые связи (VIII-XIV вв.). СанктПетербург: Издательство ИЛИ РАН.

Tamura, J. (1973). The legend of the origin of the Mongols and problems concerning their migration, Acta Asiatica, 24: 1-19.

Taşağil, A. (2002). Uygurs, u: H. C. Güzel, C. C. Oğuz i O. Karatay (ur.). The Turks. Ankara: Yeni Türkiye Publications, 414-422.

Таскин, В. С. (1984). Материаль по истории древних кочевых народов группы дунху. Москва: Наука.

Тиваненко, А. В. (1993). Святилища и культы в этнической истории кочевых племен группы дунху, u: Б. Р. Зориктуев (ur.). Этническая история народов Южной Сибири и Центральной Азии. Новосибирск: Наука, 46-66.

Тугушева, Л. Ю. (2008). Тюркские рунические письменные памятники из Монголии. Москва: ИНСАН.

Twitchett, D. (1979). Hsüan-tsung (reign 712-56), u: D. Twitchett (ur.). The Cambridge History of China. Vol. 3: Sui and T'ang China, 589-906, part 1. Cambridge: Cambridge University Press, 333-463. 
Twitchett, D. i Tietze, K.-P. (1994). The Liao, u: H. Franke i D. Twitchett (ur.) The Cambridge History of China. Vol. 6: Alien Regimes and Border States, 907-1368. Cambridge: Cambridge University Press, 43-153.

Twitchett, D. i Wechsler, H. J. (1979). Kao-tsung (reign 649-83) and the empress Wu: the inheritor and the usurper, u: D. Twitchett (ur.). The Cambridge History of China. Vol. 3: Sui and T'ang China, 589-906, part 1. Cambridge: Cambridge University Press, 242-289.

Uray-Köhalmi, K. (2002). Tungusen in der Geheimen Geschichte der Mongolen?, Acta Orientalia Academiae Scientiarum Hungaricae, 55 (1-3): 253-262, doi: 10.1556/ AOrient.55.2002.1-3.18.

Ускенбай, К. 3. (2010). Жалаирский улус ХІ - начала XIII века: к истории государствености предков казахского народа, u: М. С. Бесбаев (ur.). Теоретические и практические аспекты социально-экономического и политического развития стран Центральной Азии и СНГ: сборник материалов международной научно-практической конференции, 14 мая 2010 2, том 1. Алматы: TST- Company, 480-485.

Ушницкий, В. В. (2008). Уранхайцы: по следам одного племени в Центральной Азии, Наука и образование, 3: 72-77.

Ушницкий, В. В. (2009а). Исчезнувшее племя меркитов (мекритов): к вопросу о происхождении и истории, Вестник Новосибирского государственного университета. Серия: история, филология, 8 (3): 212-220.

Ушницкий, В. В. (2009b). Найманы: тюркское или монгольское происхождение?, Проблемы этнической истории и культуры тюрко-монгольских народов, 1: 14-20.

Ушницкий, В. В. (2010). Проблема происхождения этнонима урянхай, Гуманитарные науки в Сибири, 1: 96-99.

Ушницкий, В. В. (2011). Исторический диспут об этнической принадлежности найманов и кереитов, Проблемы востоковедения, 2: 28-34.

Ушницкий, В. В. (2013). Загадка племени меркитов: проблема происхождения и потомства, Вестник Томского государственного университета. История, 1: 191-195.

Васютин, С. А. (2010). Падение уйгурского каганата и основные пути социальнополитической эволюции кочевых обществ Центральной Азии в IX-XI вв., Вестник Кемеровского государственного университета, 4: 22-29.

Васютин, С. А. (2011). Проблемы формирования номадно-оседлого общества в империи Ляо, Вестник Бурятского государственного университета, 7: 110-115.

Викторова, Л. Л. (1958). К вопросу о расселении монгольских племен на Дальнем Востоке в IV в. до н. е. - XII в. н. е., Ученые записки Ленинградского государственного университета имени А. А. Жданова, № 256, серия востоковедческих наук, 7: 41-67.

Викторова, Л. Л. (1980). Монголы: происхождение народа и истоки культуры. Москва: Наука.

Владимирцов, Б. Я. (1934). Общественный строй монголов. Монгольский кочевой феодализм. Ленинград: Издательство Академии наук СССР.

Воробьев, М. В. (1975). Чжурчэни и государство Цзинь (Х в. - 1234 г.): исторический очерк. Москва: Наука.

Воробьев, М. В. (1994). Маньчжурия и Восточная Внутренняя Монголия: (с древнейших времен до IX в. включительно). Владивосток: Дальнаука.

Wechsler, H. J. (1979a). The founding of the T'ang dynasty: Kao-tsu (reign 618-26), u: D. Twitchett (ur.). The Cambridge History of China. Vol. 3: Sui and T'ang China, 589-906, part 1. Cambridge: Cambridge University Press, 150-187. 
Wechsler, H. J. (1979b). T'ai-tsung (reign 626-649) the consolidator, u: D. Twitchett (ur.). The Cambridge History of China. Vol. 3: Sui and T'ang China, 589-906, part 1. Cambridge: Cambridge University Press, 188-241.

Weiers, M. (1997). Herkunft und Einigung der mongolischen Stämme: Türken und Mongolen, u: S. Conermann i J. Kusber (ur.). Die Mongolen in Asien und Europa. Frankfurt am Main [etc]: Peter Lang (Kieler Werkstücke, Reihe F: Beiträge zur osteuropäischen Geschichte, 4) .

Wittfogel, K. A. i Fêng, C.-S. (1949). History of Chinese Society: Liao (907-1125). Philadelphia: American Philosophical Society.

Xu, E.-Q. (2005). Historical Development of the Pre-Dynastic Khitan. Helsinki: Institute for Asian and African Studies.

Zhao, Z. (1984). On the Origins of the Mongols, Journal of the Anglo-Mongolian Society, 9 (1-2): 43-47.

Зориктуев, Б. Р. (1993). Об этническом составе населения Западного Забайкалья и Предбайкалья во второй половине I - первой половине II тысячелетия н.е., u: Б. Р. Зориктуев (ur.). Этническая история народов Южной Сибири и Центральной Азии. Новосибирск: Наука, 121-131.

Зориктуев, Б. Р. (1995). Взаимоотношения племен Прибайкалья и Монголии в эпоху Чингис-хана, u: Б. З. Базарова і П. Б. Коновалов (ur.). “Тайная история монголов”: источниковедение, история, филология. Новосибирск: Наука, 90-95.

Зориктуев, Б. Р. (2000). Монголы и лесные народы (события 1207 и 1217 гг.), Bonросы истории, 11-12: 119-127.

Зориктуев, Б. Р. (2003). Реконструкция начального этапа ранней истории монголов, Вопросы истории, 3: 41-57.

Зориктуев, Б. Р. (2009). О происхождении и семантике этнического названия монгол, Вестник Бурятского государственного университета. Филология, 10: 125-131.

Зориктуев, Б. Р. (2010а). Этимология древнемонгольских слов börte и qoai, Вестник Бурятского государственного университета. Филология, 10: 136-139.

Зориктуев, Б. Р. (2010b). Происхождение древнемонгольских терминов киян и кият, Вестник Бурятского государственного университета. Востоковедение, 8: 96-101.

Зориктуев, Б. Р. (2011а). Актуальные проблемы истории монголов и бурят. Москва: Издательская фирма “Восточная литература" РАН.

Зориктуев, Б. Р. (2011b). Об этимологии этнонима монгол, Восток. Афро-азиатские общества: история и современность, 1: 47-57.

Жамсаранова, Р. Г. (2010). Концептосфера монгольской этнонимии в этнолингвистическом аспекте, Вестник Томского государственного педагогического университета, 7: 122128. 


\title{
Early Mongols - the Ethno-Political History to the $13^{\text {th }}$ Century
}

\section{Nenad Vidaković}

\begin{abstract}
SUMMARY
The paper examines the etnogenesis of the Mongol tribes from the period of the Rouran and Shiwei tribal alliances to the unification in the early $13^{\text {th }}$ century under Genghis Khan's leadership. The initial period of the ethnogenesis of medieval Mongols' ancestors is associated with Rouran and Shiwei tribal alliances while news about them are written in Chinese dynastic chronicles. Within the Shiwei association there was the Mengwu tribe that inhabited forest expanses of north-western Manchuria, and the Argun river basin is considered to be the original homeland of the Mongols. The directions and time of migration processes which played an important role in the transformation of part of Mongol tribes from forest hunters to steppe nomads have been further investigated. The ethnic history of the Mongol tribes is closely associated with the Turkic and Tungus-Manchurian tribes. The Turkic tribes, that inhabited the steppes of Mongolia today, had a crucial importance in the development of Mongol nomadic tribes, while the Tungus-Manchu and northern Mongol tribes shared forest expanses of Manchuria and Trans-Baikal. The following text describes the events in the Turkic khaganates and kingdoms in the north of China, which influenced the historical development of the Mongol tribes. The period of the Qidan Liao dynasty $\left(10^{\text {th }}-12^{\text {th }}\right.$ century) is of great importance because the core of the Mongol nomadic tribes was formed at that time in the northeastern Mongolia, that were gradually spreading over the steps to the west. During the Jurchen Jin dynasty $\left(12^{\text {th }}-13^{\text {th }}\right.$ century) the importance of the Mongol tribes in the steppe increased. The attempts of political unification of the Mongols appeared during that period - for the first time in the mid- $12^{\text {th }}$ century, during the reign of Khabul Khan. The final part of the paper describes the struggle of Temujin (Temüjin), the future Genghis Khan, for the unification of the Mongol-Turkic tribes. After victory over major rivals - the Tatars, Naiman, Kereyit and Merkit - Genghis Khan established authority over the Mongol tribes in 1206. This event marked the end of the first period in the ethnogenesis of medieval Mongols and the beginning of the creation of the largest state in history - the Mongol Empire.
\end{abstract}

KEY WORDS: Mongol tribes, Ergune-Kun, migration, Chinese dynasties, Genghis Khan, steppe, Turkic tribes 